\title{
COMUNICAÇÃO, CULTURA, O BALÉ MODERNO E A DITADURA NOS ANOS 70
}

Dissertação apresentada ao Programa de PósGraduação em Ciências da Comunicação, na Área de Concentração Interfaces Sociais da Comunicação, na Linha de Pesquisa em Comunicação e Cultura, da Escola de Comunicações e Artes da Universidade de São Paulo, como exigência parcial para obtenção do Título de Mestre em Ciências da Comunicação, sob a orientação do Prof. Dr. Waldenyr Caldas.

São Paulo 2008 
KARLA REGINAL DUNDER SILVA

\section{COMUNICAÇÃO, CULTURA, O BALÉ MODERNO E A DITADURA NOS ANOS 70}

Dissertação apresentada ao Programa de PósGraduação em Ciências da Comunicação, na Área de Concentração Interfaces Sociais da Comunicação, na Linha de Pesquisa em Comunicação e Cultura, da Escola de Comunicações e Artes da Universidade de São Paulo, como exigência parcial para obtenção do Título de Mestre em Ciências da Comunicação, sob a orientação do Prof. Dr. Waldenyr Caldas.

São Paulo 2008 
Membros da Comissão Julgadora:

Prof. Dr.

Prof. Dr.

Prof. Dr. 


\section{SUMÁRIO}

Introdução - pág. 03

Capítulo 1 - Um Passo para o Balé Moderno - pág. 07

Capítulo 2 - 0 Balé Stagium - pág. 38

Capítulo 3 - O Balé da Cidade de São Paulo - pág. 64

Conclusão - pág. 83

Bibliografia - pág. 87

Anexos - pág. 91 


\section{$\underline{\text { Resumo: }}$}

$O$ objetivo deste trabalho está em propor duas companhias de dança sediadas na cidade de São Paulo (Balé Stagium e o Corpo de Baile Municipal/Balé da Cidade de São Paulo) como eixos balizadores do que viria a se firmar como balé moderno nos anos 1970. Historicamente, o diálogo da dança com o seu tempo ocorre durante o período da ditadura militar (1964 - 1985) e este contexto político sugere vínculos com a natureza da linguagem que veio a se consolidar, e que passou a ser identificada como balé moderno. A hipótese da dissertação é a de que a maneira como a dança dialogava com a sociedade e trazia para o palco questões políticas e éticas, muitas vezes censuradas pela ditadura militar, tem um papel relevante para o entendimento da cultura e das questões artísticas surgidas. A metodologia usada consistiu na revisão bibliográfica e pesquisa em documentos de época como fotos, vídeos, reportagens e críticas de jornais em veículos de comunicação. $O$ resultado foi o entendimento do que representou o balé moderno na década de 70 para o público brasileiro e ao mesmo as influências européias, mesmo quando a tema se referia ao Brasil, nas produções das duas companhias aqui investigadas.

Palavras-chave: comunicação, cultura, diálogo, balé moderno, Balé Stagium, Corpo de Baile Municipal/Balé da Cidade de São Paulo, ditadura, anos 1970.

\section{Abstract:}

The objective of this paper to present a historical panorama about modern ballet in São Paulo by means of two companies: Bale Stagium and Corpo de Baile do Teatro Municipal. How the dance dialogs with your time and which political and ethics, a lot of times censured by the dictatorship government. The method consists of read books and search in documents 
like photos, videos and newspaper's texts. The result was comprehension about modern ballet in 70's for Brazilian audience and Europeans influence in theses companies.

Key Words: Comunication, Culture, Modern Ballet, Balé Stagium, Corpo de Baile do Teatro Municipal. 


\section{INTRODUÇÃO:}

Neste trabalho procuro apresentar um panorama do surgimento do balé moderno na cidade de São Paulo a partir de duas companhias: o Balé Stagium e o Corpo de Baile do Teatro Municipal. Pretendo contextualizar o nascimento desses dois grupos com a história do País e de que forma essas companhias dialogam com o seu tempo.

A escolha dessas duas companhias se deu pelo fato de serem as principais representantes do balé moderno em São Paulo tanto na década de 70 como nos dias de hoje. Também porque a produção de ambas neste período histórico representou uma transformação na produção de companhia estáveis: deixaram de lado o balé clássico tradicional.

A década de 1970 viu a modernidade crescer e ganhar espaço nos teatros. A proposta desta pesquisa está em entender a formação do balé moderno, as diferenças e semelhanças entre as duas companhias, Balé Stagium e Corpo de Baile do Teatro Municipal, as influências estrangeiras que receberam e de que maneira essa produção de dança se inseria no debate político da época.

É preciso lembrar que o Brasil vivia em plena ditadura militar (19641985). A década de 1970 começa sob a forte repressão comandada pelo presidente Emílio Garrastazu Médici (1969-1973) e sob forte censura. Em dezembro de 1968 o governo decretava o Ato Institucional de Número 5 e endurecia ainda mais o regime. O Congresso foi fechado e os direitos civis foram suspensos. O AI-5 desencadeou uma onda de prisões e censura à imprensa e à produção artística. Com o AI-5, houve o fechamento dos 
principais canais de expressão e parte da produção cultural do País entrou em crise. A censura emudeceu parte da atividade artística e intelectual.

Ao mesmo tempo em que a ditadura fechava os canais de comunicação e expressão cultural, o país via surgir um mercado consumidor de arte. Como analisa Zuenir Ventura, havia um público jovem, universitário, bem informado e de classe média disposto a consumir. De outro lado, artistas enfrentavam dificuldades para montar suas peças e produzir espetáculos devido às dificuldades impostas pelo AI5. Temas antes discutidos em peças teatrais, por exemplo, relacionados às questões políticas e éticas passaram a ser debatidos principalmente pelo Balé Stagium, que se tornou um porta-voz da situação do país.

A companhia de Décio Otero e Marika Gidali foi fundada em 1971 com o propósito de trazer para a dança questões relacionadas ao cotidiano do Brasil. Procurava levar a dança aos brasileiros, o que implicava em dançar por todos os cantos do Brasil: em teatros, praças, ruas e até mesmo em lugares inóspitos como em uma barca às margens do Rio São Francisco para levar sua dança para a população ribeirinha local. O objetivo da companhia era apresentar a dança para as pessoas que não tinham acesso a ela e propor uma reflexão sobre assuntos muitas vezes proibidos na época como a censura, a questão do índio ou da mulher.

O Corpo de Baile do Teatro Municipal foi criado em 1968 como uma companhia de dança clássica para apresentar os balés de repertório e servir para as grandes produções de óperas. O bailarino e coreógrafo Johnny Franklin assumiu a direção do grupo e atuou até 1973. Em 1974, diante de conjunturas políticas favoráveis, o Corpo de Baile passa por uma profunda transformação. O diretor Antônio Carlos Cardoso deixa de lado os tutus e 
os temas tradicionais do balé clássico e abre as portas da companhia para novos temas, privilegia as criações originais e embora a base técnica permanecesse, como até hoje permanece no treinamento da companhia, houve a abertura para a experimentação.

Tanto o Balé Stagium como o Corpo de Baile do Teatro Municipal não prescindem das técnicas do balé clássico. O Balé Stagium rompe com o modelo europeu consagrado de companhia de dança, uma vez que não apresenta em seu repertório os balés tradicionais e não entende a dança como um adorno para as óperas. Apesar de sua proposta de levar a dança aos brasileiros e fazer uma dança brasileira, o grupo segue os moldes do Balé do Século 20, do europeu Maurice Béjart. O Corpo de Baile nasce seguindo os padrões europeus, é um corpo estável do Teatro Municipal e mantido por verba pública até hoje. Rompe com a tradição temática do clássico, abre espaço para experimentações e busca um dialogo com o público de seu tempo.

O balé moderno em face à ditadura militar é um fenômeno pouco estudado. Além disso, faz-se necessário compreender melhor a dança brasileira dos anos 70 e sua importância para a cultura brasileira hoje. Afinal, as implicações do estabelecimento do balé moderno, tanto como veículo de denúncia e debate, como no seu caráter experimental, refletem na produção tanto do Balé Stagium como do Corpo de Baile do Teatro Municipal/Balé da Cidade de São Paulo ainda nos dias de hoje. A partir do balé moderno é possível compreender assuntos presentes na dança dos anos 70. Este trabalho se propõe a reunir informações e servir como um facilitador para futuras pesquisas nesta área. 
A dança foi um produto cultural que conseguiu ser o porta-voz de idéias contestadoras, protestos e críticas em uma década marcada pela censura. Por meio de coreografias, os artistas discutiam questões polêmicas e muitas vezes censuradas no teatro, nas músicas e no cinema. As companhias apresentavam-se por todo o País e como isso popularizavam o balé moderno, pois haviam abandonado o formalismo e rigor do balé, normalmente apresentado em teatros para uma elite. A proposta está em resgatar esse fenômeno, uma vez que não há uma bibliografia organizada sobre o assunto. 


\section{Capítulo 1: Um Passo para o Balé Moderno}

Neste capítulo, pretendo contextualizar o balé moderno dos anos 70 na cidade São Paulo, vinculando-o à criação do Balé do IV Centenário, criado em 1954 para comemorar os quatro séculos de fundação da cidade. Traço um breve panorama sobre o surgimento deste modo de pensar a dança no mundo, via duas companhias de balé que constituem-se como as referências históricas dessa transformação: os Balés Russos de Diaghilev, e o Ballet do Século XX, a companhia que Maurice Béjart criou na Bélgica. A hipótese aqui sustentada é a de que são elas as impulsionadoras do que sucede nos anos $70 \mathrm{com}$ duas das companhias que viriam a balizar o balé moderno em São Paulo.

A dança tornou-se moderna no início do século 20 e seus precursores procuraram maneiras diferentes da movimentação cênica usada pelo balé porque buscavam expressar idéias e sentimentos do seu tempo por meio da dança. Mas o balé também tornou-se moderno, movido por outras necessidades.

O balé havia surgido na corte italiana da Renascença. Os nobres se divertiam com música, poesia e dança nos belos salões de seus castelos. Nesse primeiro momento, a dança se resumia a graciosos movimentos de mãos, braços, tronco, cabeça e pés, associando-se também à pantomima. Os gestos eram sutis e limitados pelas pesadas roupas usadas na corte, naquela época. Em 1626 foi apresentado o primeiro ballet à entrée, no qual bailarinos substituíram os nobres nos trechos de solistas na apresentação do Ballet de la Douairière de Billebahaut em Paris. Mesmo assim ainda havia a presença do rei e de sua corte.(CAMINADA, 1999, p.92). Em 1632 houve a apresentação de Effects de la Nature, o primeiro a ser encenado em 
uma casa de espetáculos, ainda que não houvesse separação entre público e palco. O balé caminhava para a profissionalização.

\begin{abstract}
Havia se invertido o espírito dos espetáculos: enquanto nas mascaradas, o objetivo a ser alcançado era apenas o prazer, movido pela vaidade e bajulação, nos ballets à entrée já entrava em questão a necessidade de agradar o público, sobretudo um novo público. O balé começou aí o seu processo de libertação do amadorismo, em busca de adquirir o status de arte de verdade. Com a morte de Luís XIII, em 1643, durante um certo tempo nenhum ballet foi encenado na corte francesa; poucos anos depois, com o novo soberano Luís XIV, fatos decisivos tiveram lugar, colocando definitivamente o ballet, como uma arte, e uma arte de profissionais. (CAMINADA, 1999, p.92)
\end{abstract}

Levado para a França pela rainha Catarina de Médicis, o balé ganhou status profissional após a criação da Academia Real de Balé, por Luis XIV, que reinou entre 1643 a 1715 . Luís XIV estreou pela primeira vez como bailarino, no balé Cassandra, em 1651, espetáculo coreografado por Charles-Louis-Pierre de Beauchamps. Luis XIV era um praticante da dança. $\mathrm{O}$ rei bailarino destacava-se nas produções em que dançava para e com os seus nobres, sempre nos papéis centrais. Em 1661 foi criada a Academia Real de Balé, poucos registros foram deixados sobre esse período, logo pouco se sabe sobre o seu funcionamento, mas sabe-se que "a França passou definitivamente a ser a pátria da dança, embora sua regularidade e equilíbrio tenham sido conquistados à custa de uma certa frieza e rigidez, em detrimento da parte expressiva, da vitalidade e do naturalismo; e assim seguirá até surgir Noverre." (CAMINADA, 1999, p. 104).

"Por um lado, a virtuosidade é a conseqüência natural da primazia da forma sobre o conteúdo. Esta tendência é reforçada por uma profissionalização que se acelera. A ópera Xerxès mostra que era possível, já em 1660, recrutar vinte e 
oito dançarinos profissionais de uma só vez; a partir de 1672, a criação da Academia Real de Música e Dança garantirá uma verdadeira profissão aos dançarinos, com rendas fixas, no contexto de uma competição para entrar no corpo de baile e chegar a empregos de solista".

(BOURCIER, 2006, p. 116)

Foi um professor da Academia Real, Charles-Louis-Pierre de Beauchamps, quem criou as cinco posições para os pés, a base do balé clássico que continua vigorando na atualidade. Beauchamps seguiu as diretrizes de Luís XIV para as artes, impondo à dança um sistema que tende à beleza das formas.

\footnotetext{
"Por outro lado, regularidade, beleza formal, virtuosismo são o preço da técnica estabelecida por Beauchamps. São fronteiras estreitas, de certa forma uma ameaça de endurecimento: a repetição mata a inspiração, a não ser que esta forma idêntica seja revitalizada por uma mudança de finalidade. É o que tentará Noverre, de acordo com as idéias de seu tempo, um século mais tarde." (BOURCIER, 2006, p. 116)
}

Um personagem importante neste período da história do balé é JeanBaptiste de Lully. Lully agradou ao rei ao coreografar o Ballet de la nuit (1653), Luís XIV:

desempenhou o papel de Sol e, com a alcunha de 'Roi Soleil', passou à história. Na verdade, Luís XIV foi associado ao astro-rei desde o seu nascimento, quando cunhou-se uma medalha que o proclamava 'O Sol nascente da Gália'; o próprio enredo do ballet citado mostrava que o personagem desempenhado pelo rei tinha uma razão de ser política e importante; nele, o Sol adentrava no salão, com a finalidade de clarear e livrar uma casa em chamas (a França) de saqueadores (o povo), que assim agiam protegidos sob a escuridão da Noite. Com ele entravam também a Honra, a Graça, o Amor, a Riqueza, a Vitória, a Fama e a Paz. O ballet, o último do gênero, constituiu-se num êxito, em função também dos 
versos de Isaac de Benserade e do talento, versatilidade e habilidade política de Lully. (CAMINADA, 1999, p. 103, 104)

Lully foi nomeado superintendente de música em 1661, "a partir de quando reinou de forma absoluta sobre o teatro musical na França." (BOURCIER, 2006, p. 137).

O papel de Lully na concepção da dança, que foi, em quase todas as suas obras posteriores, reduzida ao estado de divertimento, é importante. Testemunha o secretário: 'Lully participou dos balés das óperas seguintes quase tanto quanto Beauchamps. Reformulava as entrées, imaginava passos de expressão convenientes ao tema e, quando havia necessidade, punha-se a dançar diante dos dançarinos para lhes fazer compreender rapidamente suas idéias. No entanto, não havia aprendido a dança e, assim, dançava por capricho e por acaso, mas o hábito de ver danças e um extraordinário talento para tudo o que se referisse aos espetáculos, faziam-no dançar com gosto e com uma vivacidade bem agradável.' Com efeito, quase todos os anos, até sua morte, em 1687, Lully apresentava uma tragédia lírica com divertimentos dançados de forma repetitiva, cuja execução era sempre garantida por Beauchamps, primeiro mestre de balé da Academia. Vimos em que medida: só se encarregava da técnica. (BOURCIER, 2006, p. 138).

Pode-se afirmar que o balé recebeu um grande impulso durante o reinado de Luís XVI, Os espetáculos passaram a ser apresentados para uma platéia pagante, o que modificou profundamente as relações entre o público e os intérpretes. Outra mudança profunda ocorreu na sistematização da técnica:

Os princípios, em cima dos quais Pierre Beauchamps construiu a base do academismo e as inovações da técnica de elevação, transformaram a arte do ballet na mais duradoura de todas as formas de dança, através de cujo preparo o bailarino pode executar quase tudo o que o coreógrafo imagine para o seu corpo; 
como um alfabeto, com o qual é possível falar inúmeros idiomas, tal o significado da técnica de dança acadêmica ou dança 'clássica'. (CAMINADA, 1999, p. 105)

No século 18 o balé passará por novas transformações, uma síntese da dança bailada com a dança pantomímica ou dança pura versus dança expressiva, o chamado balé de ação. (CAMINADA, 1999, p.121). Não é possível falar do balé de ação sem apresentar Jean George Noverre. Durante o reinado de Luís XVI assumiu como maître $d u$ ballet da Academia Real de Dança por dois anos, em 1776-78. Atuou na Ópera Comique de Paris e também atuou em Berlim, Dresden, Estrasburgo, Marselha, Lyon, Viena, Stuttgart e Londres.

As idéias de Noverre sempre estiveram muito além de seu tempo; sua preocupação com a expressividade já refletia o pré-romantismo e a arte de imitar, a que se referia, era baseada no ideal aristotélico segundo o qual 'imitar não é copiar mas apresentar a imagem das paixões humanas.' Considerado o verdadeiro autor do ballet d'action, o artista afirmava: 'o bailado tem que ser concebido como um espetáculo independente, apoiado num enredo e no qual o movimento e a ação coincidam completamente. $\mathrm{O}$ ballet deve ser um drama dançado, que corresponda em tudo ao drama falado ou cantado e, como este, deverá seguir a teoria poética de Aristóteles - ter exposição, desenvolvimento e solução. Os outros preceitos são a divisão do ballet em atos e cenas, e personagens de contornos firmes participando de cenas contrastantes. A cada movimento de dança deverá corresponder um movimento de espírito. Os momentos importantes devem ter para o espectador a força plástica de uma pintura. As mãos dos bailarinos devem dizer alguma coisa; se os músculos do rosto carecem de expressão e os olhos não declamam, o resultado será falho e a impressão, falsa. É preciso arrancar as máscaras horrendas, queimar as ridículas perucas, suprimir os vestidos incômodos, banir as anquinhas mais incômodas ainda e substituir a tendência à rotina...'. Em suma, o drama de ação de Noverre exigiu trama, lógica e conexão; era uma obra de arte conjunta, onde se 
relacionavam a dança, a poesia, a música e a decoração, na procura de um efeito de unidade; um maître de ballet deveria reunir em si as qualidades de todas essas expressões de arte. (CAMINDA, 1999, p.123)

Com o passar dos anos, mais precisamente no século 18, JeanGeorge Noverre escreve, em 1760, a primeira edição de Lettres (Cartas), na qual apresenta a sua doutrina. Em síntese, dois princípios básicos dominam as idéias de Noverre:

- O balé deve narrar uma ação dramática, sem se perder em divertimentos que cortam o seu movimento; é o 'balé de ação';

- a dança deve ser natural, expressiva, o que Noverre chama de pantomima. (BOURCIER, 2006, p. 170).

O 'balé de ação’, mais adiante, colaborará com o nascimento do balé romântico, na França, em 1832.

Foi anunciado, no final do século XVIII, por J.J. Rousseau, e triunfou com Chateaubriand, no início do século XIX, na medida em que é um culto do indivíduo, na medida em que o indivíduo é que se torna tema da arte. A ênfase sobre o indivíduo, mais do que sobre um arquétipo social, acarreta a rejeição das regras impostas pela sociedade do século XVII : a sensibilidade tem primazia sobre a razão; o coração e a imaginação assumem o poder, sem o controle de uma autocensura. O resultado é uma inflação dos sentimentos e de sua expressão. O balé também vai se tornar a expressão de sentimentos pessoais, sob uma forma que será diferente dos gestos rigidamente codificados há um século e meio. (BOURCIER, 2006, p. 199).

O Romantismo foi, de certa forma, "uma revolta pequeno-burguesa contra o classicismo da nobreza, contra as normas e os padrões da época, contra a forma aristocrática e contra um conteúdo que excluía todas as 
soluções 'comuns'.'(CAMINADA, 1999, p. 126). Com o Romantismo do século 19, produzem-se coreografias em um universo onírico repleto de fadas, bruxas e outros seres sobrenaturais ou mitológicos. Uma grande novidade caracteriza a técnica romântica: as pontas. O início do balé romântico é marcado com A Silfide, em 18 de março de 1832.

O balé não segue um enredo, consiste em uma dança poética com a presença das fantasmagóricas sílfides que se opõem a uma ambientação das ruínas de um mosteiro. Todas as ações dependem da musicalidade e da delicadeza do estilo, os solos exigem nuances expressivas e uma suave técnica. $\mathrm{O}$ corpo de baile no palco está presente de maneira decorativa quando não estão dançando. (VAUGHAN-CLARKE, 1977, p. 328,329).

Vale destacar dois aspectos que se sobressaíram no Romantismo: a atenção ao colorido da natureza e ao elemento exótico que pudesse estar ali e a preferência pelo sobrenatural, pelo espiritual e pelo irracional. Em $A$ Sílfide marca a presença, como próprio título sugere, da presença do sobrenatural. Um ser alado, a sílfide, se apaixona pelo mortal James.

Já temos aqui um dos temas típicos da coreografia romântica: um mortal amado por um espírito. $\mathrm{O}$ primeiro ato se desenvolve num contexto terrestre, o segundo no domínio irreal dos espíritos. O traje dos espíritos, uma túnica semilonga de musselina, fez com que fosse chamado 'o ato branco'. O principal da ação é simples: a oposição entre dois mundos, o material e o imaterial. (BOURCIER, 2006, p. 203).

Muitas coreografias deste período ficaram conhecidas como 'balés brancos', nesses atos havia a preocupação do bailarino surgir com o nãopeso para dar a sensação de um ser sobrenatural em cena. E uma das obras mais conhecidas desta fase é Giselle (1841). "Giselle é a obra mestra absoluta, que sintetiza de forma admirável todas as aspirações técnicas, 
dramáticas, constituindo-se no ponto principal do repertório das companhias clássicas até nossos dias." (CAMINADA, 1999, p.139).

Outra pequena revolução viria com Marius Petipa, o coreógrafo que assina a criação de peças famosas como A Bela-Adormecida (1890) e O Lago dos Cisnes (1895) entre outros, com trilha musical de Tchaikovsky. "Ele não apenas coreografou mais do que 60 balés, como também combinou a escola francesa com o virtuosismo dos italianos e o temperamento dos russos, criando a dança clássica que nós conhecemos hoje." (CLARKE-VAUGHAN, 1977, p.274,275).

Petipa adotará o hábito de rechear seus balés com episódios que nada têm a ver com o assunto, mas que são pitorescos, sem perceber que transformava o 'balé de ação’ de Noverre numa super-revista dançada, do tipo grande espetáculo. (BOURCIER, 2006, p. 217).

Todo esse passado do balé clássico ganha uma outra formulação com Sergei Diaghilev (1872-1929). Diaghilev foi um empresário russo e diretor de companhia. Nasceu em uma família nobre, estudou direito em São Petersburgo. Lá conheceu jovens artistas e fundou a revista Mir Iskussiva (Mundo da Arte), que até 1904 se dedicou à difusão da arte russa.

Foi admitido no serviço dos ts. Imperiais e no T. Mariinski foi responsável pelo anuário da casa e pela prod. da óp. Sadko e do b. Sylvia. Orgulhoso e desafiador, entrou logo em litígio com a burocracia do t., sendo demitido (1901). Organizou diversas exposições de arte e música russas em S. Petersburgo e Paris (1904-08). Após o sucesso de Boris Godunov, em Paris e vendo o estado precário da dança naquela cidade, decidiu formar um grupo com os melhores dançarinos imperiais, o que levaria à formação de uma cia. que duraria de 1909 a 1929. A importância de Diaghilev para a dança é incomensurável: ele retirou a arte da decadência em 
que se encontrava, trouxe para trabalhar consigo a nata dos coreógrafos, dançarinos, músicos e cenógrafos da época, convencendo pintores como Matisse e Picasso a criarem para o balé. Era absolutamente implacável com a mediocridade ou com quem desafiasse ou se colocasse no seu caminho, chegando a demitir Nijinski, que era a estrela máxima da cia., e até coreógrafos como Fokine e Massine. Para ele, o mais importante era a cia. e sua continuidade. Ao perder o apoio oficial, dependeu de seus ricos amigos em Paris e Londres para manter o grupo unido, mas mesmo nos piores momentos jamais cedeu em matéria de qualidade. A ele se deve não apenas a revitalização da dança como arte viva, mas também a abertura de caminho que chegaria ao modernismo com Wigman e Graham, já que Diaghilev romperia com as regras estioladas da dança acadêmica de então. Foi, sem dúvida, um dos grandes nomes de toda a história da dança. (FARO, SAMPAIO, 1989, p.119)

Diaghilev como seu Balé Russo, a partir de 1909 e por 20 anos, agitou a cena européia. Ao chegar em Paris, Diaghilev percebeu que o balé na França não estava tão desenvolvido quanto na Rússia, principalmente no que tange a qualidade técnica dos bailarinos. Por outro lado, a Rússia necessitava de "renovação, já que a qualidade das produções não acompanhava a dos dançarinos. O longo reinado de Petipa chegara ao fim e impusera regras acadêmicas que se transformaram em verdadeira camisa-de-força." (FARO, SAMPAIO, 1989, p.42). O jovem coreógrafo Michel Fokine, por exemplo, encontrava diversas dificuldades burocráticas para apresentar suas coreografias em um palco, por exemplo

Em 1909 Diaghilev organizou uma cia., selecionando os melhores bailarinos de S. Petersburgo e Moscou, entre os quais Pavlova, Karsavina e Nijinski. Sua estréia em Paris (Th. Du Châtelet, 19.5.1909) foi uma revelação e marcou o início de uma revolução que daria enorme impulso ao balé como arte viva e produtiva. O primeiro programa incluía duas 
obras de Fokine, Le pavillon d'a Armide e Danças Polovitsianas do Príncipe Igor e diversos números reunidos sobre o coletivo de Le festin. Até 1911 a cia. apresentou-se em Paris e Londres, aproveitando as férias dos bailarinos russos (maio a julho). Mas Diaghilev, que fizera inimigos importantes na alta burocracia tzarista, passou a enfrentar grandes dificuldades para montar a cada ano uma cia. Decidiu assim partir definitivamente para o Ocidente, sediando-se em M. Carlo. Após 1914 seus laços com os teatros imperiais foram totalmente cortados e os dançarinos tiveram de optar entre segui-lo ao Ocidente ou permanecer na Rússia. Homem astuto, culto e batalhador, Diaghilev logo cercou-se da nata de compositores e cenógrafos europeus, partindo para produções de uma qualidade há muito ausente nos palcos ocidentais. A cia. viajava não apenas por toda Europa, mas foi a primeira a dançar no T. Mun.-RJ (1913 e 1917), indo a São Paulo, Buenos Aires e EUA. Nos anos críticos após a Primeira Guerra Mundial, a cia. viu sua sobrevivência ameaçada por problemas financeiros, contornados pela legião de ricos admiradores que Diaghilev fizera em Paris, Londres e Madri. Diaghilev preconizava a dança como uma arte, em que a coreografia, a música e a cenografia deveriam ter a mesma importância. A lista de artistas que com ele trabalhou naqueles tempos é um verdadeiro dicionário de gênios das décadas de 20 e 30 deste século. Diaghilev partiu inclusive parao experimento, liberando a dança dos grilhões de um academicismo ferrenho e possibilitando a abertura que, além de permitir à dança acadêmica desenvolver-se e chegar até Balanchine, Robbins ou Cranko, deu margem ao surgimento de nomes como Graham e Wigman. A cia. dissolveu-se com a morte de Diaghilev (1929), tendo se apresentado pela última vez em Vichy (4.8.1929). (FARO, SAMPAIO, 1989, p.42)

\section{O início do século 20 é marcado pelo Modernismo:}

Sob o termo genérico Modernismo resumem-se as correntes artísticas que, na última década do século XIX e na primeira do século $\mathrm{XX}$, propõem-se a interpretar, apoiar e acompanhar o esforço progressista, econômico-tecnológico, 
da civilização industrial. São comuns às tendências modernistas: 1)a deliberação de fazer uma arte em conformidade com sua época e a renúncia à invocação de modelos clássicos, tanto na temática como no estilo; 2) o desejo de diminuir a distância entre as artes 'maiores' (arquitetura, pintura, escultura) e as 'aplicações' aos diversos campos da produção econômica (construção civil corrente, decoração, vestuário, etc.); 3) a busca de uma funcionalidade decorativa; 4) a aspiração a um estilo ou linguagem internacional ou européia; 5) o esforço em interpretar a espiritualidade que se dizia (com um pouco de ingenuidade e um pouco de hipocrisia) inspirar e redimir o industrialismo. Por isso, mesclam-se nas correntes modernistas, muitas vezes de maneira confusa, motivos materialistas e espiritualistas, técnico-científicos e alegórico-poéticos, humanitários e sociais. Por volta de 1910, quando ao entusiasmo pelo progresso industrial sucede-se a consciência da transformação em curso nas próprias estruturas da vida e da atividade social, formar-se-ão no interior do Modernismo as vanguardas artísticas preocupadas não mais apenas em modernizar ou atualizar, e sim em revolucionar radicalmente as modalidades e finalidades da arte. (ARGAN, 2004, p. 185).

$\mathrm{Na}$ dança, isso se reflete em novas maneiras de dançar diferentes do balé clássico que, mais adiante, viriam a irrigar os modos do próprio balé existir, tornando-o moderno também. Para entender a mudança que viria a se dar no balé, vale situar a contribuição de alguns que contribuiram para essa transformação. Émile Jaques-Dalcroze, professor de música nascido na cidade de Viena, na Áustria, é um deles.

Músico e pedagogo suíço, Émile Jaques-Dalcroze interessa à história da coreografia porque descobriu uma nova abordagem do movimento: a rítmica. Pianista, regente ocasional, professor do Conservatório de Genebra, constata que uma educação corporal pode ajudar na iniciação musical. Para ele, o corpo é ponto de passagem obrigatório entre pensamento e música: o pensamento só pode captar o ritmo se ele for ditado pelo movimento. É o seu primeiro passo" (BOURCIER, 2006, p. 291). 
Émile Jaques-Dalcroze desenvolveu um sistema de treinamento de sensibilização musical denominado eurritmia, no qual tinha a função de transformar o ritmo em movimentos corporais.

Cria, então, uma educação psicomotora com base na repetição de ritmos, criadora de reflexos, na progressão da complexidade e da sobreposição de ritmos, na decifração corporal, na sucessão do movimento: a música suscita no cérebro uma imagem que, por sua vez, impulsiona o movimento, que se torna expressivo caso a música tenha sido captada corretamente. As consequiências pedagógicas são o desenvolvimento do sentido musical em todo o ser sensibilidade, inteligência, corpo -, que fornece uma ordem interior que, por sua vez, comanda o equilíbrio psíquico. (BOURCIER, 2006, p. 291 e 292,).

Dalcroze afirmava que toda atividade visual ou auditiva começa com um simples registro de imagens e sons, e as faculdades receptoras do olho e do ouvido vão somente desenvolver uma atividade estética quando o sentido muscular estiver suficientemente desenvolvido para converter sensações registradas em movimento, pretendendo usar movimentos corporais para demonstrar a percepção e compreensão do ritmo, afirmando que o som podia ser percebido por qualquer parte do corpo. Teve como discípulos nomes ilustres como Rudolf Von Laban (1879-1958) e Mary Wigman (1886-1973).

O mérito de Dalcroze foi descobrir uma pedagogia do gesto; seu aluno transformará, mesmo traindo-a, o que era análise pragmática em poesia e dramaturgia do movimento." (BOURCIER, 2006, p. 293).

Outro dos que se destacaram no início do século 20 foi Rudolf Von Laban (1879-1958)², que lança as bases de uma nova dança, elaborando os

\footnotetext{
${ }^{2}$ Rudolf Von Laban (1879-1958) nasceu na Hungria e estudou por sete anos na escola de Belas Artes em Paris. Durante a Primeira Guerra Mundial, Laban se fixa na Suíça
} 
componentes essenciais do movimento corporal: espaço, tempo, peso e fluência. Ele propôs um espaço tridimensional diferente daquele plano limitado pela frontalidade com a platéia, típico do balé clássico, servindo de referência para o dançarino, organizando o movimento em volume com diversas direções. Em sua teoria, o espaço é concebido a partir do corpo do bailarino e dos limites do seu entorno, desta forma o dançarino poderia se movimentar livremente no espaço, independente do seu deslocamento, guiando-se, então, pela kinesfera, que é a demarcação dos limites de extensões dos membros do corpo humano em relação ao próprio eixo. Seu estudo possibilitou desvencilhar o movimento corporal da arte dramática, da música e das demais possibilidades de passos preestabelecidos.

Laban nos ensinou que por meio do corpo adquirimos conhecimento. Ele, já na sua época, dizia que não é possível separar conceitos abstratos, idéias e/ou pensamentos, da experiência corporal. Ela é a base primeira do que podemos dizer, pensar, saber e comunicar. A noção de que corpo e mente fazem parte de uma mesma realidade é base da Arte de Movimento de Rudolf Laban" (RENGEL, 2003, p. 13).

Laban define duas formas de ações corporais básicas, em que todo movimento as possui, estas formas são: Recolher e Espalhar. O movimento de Recolher parte da periferia do corpo para o seu centro, denominado movimento centrípeto, e, o movimento de Espalhar, que parte do tronco para as extremidades é denominado movimento centrífugo.

onde monta uma escola de arte do movimento ao mesmo tempo em que começa a elaborar um método de notação em dança. Em 1938 muda-se para Londres, onde funda o centro Modern Educational Dance. Publica o livro Effort em 1947, no ano seguinte lança Modern Educational Dance e em 1950 Mastery of Movement on the Stage completado em 1954 por Principles of Dance and Movement Notation. Os princípios básicos de Laban são: dividir o espaço em três níveis (vertical, horizontal e axial) sobre os quais se inscrevem doze direções de movimento. 
O corpo do bailarino segue direções definidas no espaço. Essas direções configuram formas e desenhos no espaço. Na verdade, a dança pode ser considerada como a poesia das ações corporais no espaço. (LABAN, 1978, p. $53)$.

Laban influenciou artistas como Mary Wigman e Kurt Jooss. Mary Wigman (1886-1973) foi aluna e assistente de Laban na Suíça.

Concordam profundamente não a respeito das teorias cinéticas do mestre, cuja vontade de clareza intelectual nada tem a ver com o temperamento da dançarina, mas a respeito do sentido profundo da dança: a revelação de tudo o que jaz escondido no homem" (BOURCIER, 2006, p. 297).

Mary Wigman foi bailarina, coreógrafa e professora. Estou com Dalcroze e Laban. Sua primeira apresentação ocorreu em 1914. Abriu uma escola de dança em Dresden, que se tornou o berço da dança moderna alemã.

Em toda a Europa proliferaram escolas baseadas em sua técnica. Durante o período nazista, foi vítima de perseguições e só depois em 1945 reabriu sua escola. Sua obra coreográfica foi extensa, destacando-se: Hexentanz I e II (1914 e 1926), Die Feier (1920), Die Sieben Tanzen dês Leben (1921), Ein Tanzmärchen (1925), Das Opfer (1933), Totetanz II (1928), Saül (1954), Catulli Carmina e Carmina Burana (1955), Alkestis (1958), todos para o T. N. de Manheim; A Sagração da Primavera (1957) e Orpheus und Euridyke (1961), ambos para a Op. De Berlim. Escreveu Deustche Tanzkunst (Dresden, 1953) e Die Sprache dês Tanzes (Stuttgart, 1963). Prêmio Schiller (1954) e Prêmio da Crítica Alemã (1961). (FARO, SAMPAIO, 1989, p.416)

A dança de Mary Wigman é marcada pelo trágico, para ela a arte é a "manifestação extática da existência". 
Formar o dançarino é, portanto, torná-lo consciente dos impulsos obscuros que estão dentro dele. Nada de sistemas preestabelecidos, menos ainda adestramento corporal. É preciso se pôr a escuta de si mesmo, onde se pode ouvir a repercussão do eco do mundo. Então os vislumbres de conhecimento que começam a brotar exprimem-se por esboços de gestos que contribuem para a conscientização das pulsões internas" (BOURCIER, 2006, p.. 299).

Em cena, os movimentos da coreógrafa partem do tronco. "A dança moderna marca o retorno ao peso, à queda e ao pé descalço. Outras nuanças serão introduzidas nas diferentes qualidades de 'transferência de peso', centro das atenções de uma Doris Humphrey ou de uma Mary Wiagman" (GODARD, 1999, p.23). Na dança de Mary Wigman, a música, como Dalcroze, "é o meio indissociável entre o ritmo corporal e o ritmo mental" (BOURCIER, 2006, p. 299).

Mary Wigman contribuiu para dar um sentido trágico e quase divinatório à dança, para liberar o dançarino do vocabulário corporal, atribuindo-lhe total responsabilidade sobre a expressão" (BOURCIER, 2006, p. 300).

Wigman tem especial importância para o Brasil, pois uma de suas alunas, Yanka Rutska, trouxe os seus ensinamentos para a primeira faculdade de dança brasileira, criada em 1956, na Universidade Federal da Bahia.

Outro seguidor de Laban foi Kurt Jooss cuja principal obra foi $A$ Mesa Verde, de 1932. "Jooss associou intimamente a dança ao teatro, mais particularmente à mímica, desde A Mesa Verde. Como para os americanos e para Wigman, a emoção profunda deve modular os movimentos do corpo. Quer que estes movimentos - aqui encontramos uma idéia de Dalcroze - 
sejam reduzidos aos mais característicos. Donde um estilo entrecortado por uma sucessão de imagens fortes, mas vivo e colorido, que chama de “essencialismo"” (BOURCIER, 2006, p. 301). Jooss, por sua vez, influenciará o trabalho da coreógrafa alemã Pina Bausch.

François Delsarte (1811-1871) também foi um dos precursores da dança moderna que viria a colaborar com a modernização do balé. Foi um cantor que não conheceu o sucesso, desta forma passou a refletir mais sobre suas experiências passadas e a relação entre a alma e o corpo, e as manifestações corporais que traduzem o que o corpo sente interiormente. Seu trabalho começa com a catalogação de gestos e estados emocionais em cena, examina diferentes casos patológicos, observa a manifestação de loucura e a dissecação de cadáveres. Aos poucos, constata que a uma emoção, a uma imagem cerebral, corresponde a um movimento ou, ao menos, uma tentativa de movimento. Surge, então, a chave da dança moderna: a intensidade do sentimento comanda a intensidade do gesto.

Delsarte subdividiu o corpo sistematizando o gesto e a expressão humana em três categorias: gestos excêntricos, concêntricos e normais, estabelecendo também três zonas de expressão: cabeça, tronco e membros. Conseqüentemente conclui que: todo o corpo é mobilizado para a expressão, principalmente o torso, que todos os dançarinos modernos, de todas as tendências consideram a fonte e o motor do gesto. A expressão é obtida pela contração e relaxamento dos músculos: tension e release, que futuramente serão as palavras-chave do método de Martha Graham. A extensão do corpo está ligada ao sentimento de auto-realização, enquanto que o sentimento anulação se traduz por um dobrar do corpo. 
As idéias de François Delsarte foram passadas oralmente em suas conferências sendo somente sistematizadas após sua morte por um de seus discípulos Alfred Giraudet, em 1895: Physionomie et Gestes - Méthode Pratique d'après le Système de François Delsarte (Paris). Nos Estados Unidos as idéias de Delsarte foram expostas por um ator americano chamado Steele MacKaye, que havia trabalhado com ele e considerado, pelo próprio Delsarte, o seu herdeiro espiritual. Três discípulos de François Delsarte encaminharão suas idéias diretamente à dança moderna: Isadora Duncan (1878-1927), Ted Shawn (1891-1972) e Ruth Saint-Denis (1878?1968).

Nascida em São Francisco, nos Estados Unidos, Isadora Duncan (1878-1927) é um dos nomes de destaque na dança moderna. Aprendeu a dançar na infância e seu aprendizado foi marcado pela técnica acadêmica. No entanto, Isadora não era uma criança comum e "acha completamente natural tornar-se professora aos quatorze anos" (BOURCIER, 2006, p. 247). Ela começou a ensinar dança ainda menina e passou a refletir e a criar um jeito próprio de dançar, longe das sistematizações do balé.

Para Isadora Duncan "a dança é expressão de sua vida pessoal" (BOURCIER, 2006, p. 248). Isadora inspirava-se na contemplação, podendo sentir e transformar-se em elementos da natureza.

A técnica lhe parece sem interesse: fazer gestos naturais, andar, correr, saltar, mover seus braços naturalmente belos, reencontrar o ritmo dos movimentos inatos do homem, perdidos há anos, 'escutar as pulsações da terra', 'obedecer à lei da gravitação', feita de atrações e repulsas, de atrações e resistências', conseqüentemente encontrar uma 'ligação' lógica, onde o movimento não pára, mas se transforma em outro, respirar naturalmente, eis seu método" (BOURCIER, 2006, p. 248). 
A música clássica é sua fonte de emoções traduzidas em movimentos corporais. Seus modelos estéticos são os gregos, figuras de vasos e esculturas. Sempre se apresentava de túnica grega, descalça e com sua echarpe inseparável. Procurava ter ao fundo de suas apresentações uma cortina preta para tornar seus gestos mais legíveis. Antes da sua trágica morte, em 1927, estrangulada por sua própria echarpe, presa na roda de seu carro em movimento, escreveu suas memórias, My Life, que narra a sua intensa vida.

Ainda, ligado às idéias de François Delsarte cabe ressaltar a Denishawnschool, escola fundada e dirigida por Ruth Saint-Denis e Ted Shawn, em Los Angeles em 1914. Com uma grande participação teórica de Ted Shawn, ele reivindica a ruptura completa com a dança tradicional, recorrendo às danças orientais, assimilando apenas seu espírito e não a técnica exatamente; no plano mental, considera que são liturgias que colocam o dançarino em contato com a divindade. Por esse motivo, exige concentração fervorosa dos alunos. Tecnicamente, utiliza todo o corpo, considerando o tronco, e não mais os membros inferiores, como ponto de partida de qualquer movimento, buscando reforçar a impulsão nervosa situada no plexo solar, de modo que cada músculo esteja imediatamente disponível para traduzir o impulso interior. A Denishawn foi uma escola que ensina várias disciplinas: anatomia, música, cultura geral e treinamento corporal.

Martha Graham (1894-1991) estudou na Denishawnschool em 1916. Em 1926 deu início a carreira solo e no ano seguinte formou sua escola, o que a levou a fundar em 1929 a sua própria companhia de dança com alunos de sua escola. Antes, em 1923, Martha Graham ruma para Nova York dedicando-se ao ensino. Entre pesquisas e reflexões ela estabelece os 
fundamentos de sua dança. Rejeita a relação de Isadora Duncan com os ritmos da natureza, afirmando que não quer ser flor, árvore, onda ou nuvem. Ela também passa a rejeitar as idéias da Denishawnschool, dizendo estar farta de deuses indianos e rituais astecas. Sua busca passa a ser expressar a cultura norte americana à problemática do século 20, no qual a máquina interfere no ritmo do gesto humano e a guerra chicoteia as emoções, desencadeando os instintos.

A origem da dança está no rito, esta aspiração de todos os tempos à imortalidade. No início, o rito nasceu do desejo de entrar em contato com os seres que poderiam conceder a imortalidade do homem. Hoje, praticamos outra espécie de rito... pois procuramos uma imortalidade diferente: a grandeza que pode ser encontrada no homem. Sublinharemos, de passagem, a exatidão da intuição de Graham, que só podia conhecer a Antigüidade clássica, mas que adivinhou os ritos que a precederam. Esta busca nas profundezas da alma, este movimento do espírito para mergulhar no desconhecido do ser - Graham se interessou pelas teorias freudianas - implicam um esforço mental que será traduzido por movimentos corporais reveladores: tensões, torsões" (BOURCIER, 2006, p. 276).

Toda a sua dança provém do duplo princípio da vitalidade do movimento: tension-release (contrair-relaxar) e toda a técnica é fundamentada na respiração. Eis alguns fundamentos da escola de Martha Graham: o plexo solar é considerado fonte de energia para o movimento; o tronco concentra as forças vitais que se irradiam para os membros; a região pélvica como ponto de apoio e representante da sexualidade; a força do gesto acontece em função da força da emoção. Para Martha Graham um praticante de dança moderna precisa saber respirar, porque a intensidade do movimento, duração e efeito, se condicionarão de acordo com o ritmo da inspiração-expiração. 
A aula precisa começar com exercícios sentados no chão, pois nessa posição o dançarino pode controlar melhor todos os músculos do tronco em alongamento e contração, tornando o aquecimento mais eficiente, e em seguida, exercita-se de pé, preferencialmente em círculo, evitando o espelho por uma maior conscientização muscular, pois esta consciência deverá independer da visão. Martha Graham influenciou, diretamente, nos estudos Lester Horton, e Merce Cunningham. Duas personalidades que irão contribuir para o surgimento da dança pós-moderna nos Estados Unidos.

\section{O Balé Moderno, a dança moderna e o Brasil dos anos 70}

Durante a ditadura militar, na década de 70, na vigência do AI-5 - o Brasil dos anos de chumbo a dança moderna se torna um porta-voz da situação do Brasil. Os militares tomaram o poder em 1964 a 1985. A década de 1970 começa com a repressão do Regime Militar comandado pelo presidente Emílio Garrastazu Médici que preside o país de 1969 a 1974 sob forte censura. Em dezembro de 1968, em nome da segurança nacional, o governo decretava o Ato Institucional número 5. O Congresso foi fechado, os direitos civis foram suspensos, incluindo-se aí a figura jurídica do Hábeas Corpus para os casos de infração da Lei de Segurança Nacional. O AI-5 desencadeou uma onda de prisões e censura à imprensa e à produção artística. O ano de 1969 foi marcado pelo afastamento de Costa e Silva (1967-1969), em seu lugar assumiu uma Junta Militar, que depois elegeu Emílio Garrastazu Médici, o que na prática significou o endurecimento da repressão e censura. 
Mesmo diante desse panorama, a arte encontrou meandros para se manter como um canal de expressão. Nas mídias, surgiu a imprensa alternativa, representada por O Pasquim, Opinião, Bondinho, Versus, Movimento entre outros. Na dança, o balé entrou em crise, sem verbas ou apoio do Estado. Contava apenas com o interesse de alguns empresários, que eventualmente patrocinavam alguns espetáculos, na maioria das vezes, de companhias estrangeiras. Em 1972, o Royal Ballet apresentou-se no Teatro Municipal de São Paulo e a classe artística da dança protestou, por meio de um abaixo-assinado, pelas verbas inexistentes para o balé brasileiro e as somas altas destinadas às companhias estrangeiras.

O período compreendido entre 1970 e 1979 sofreu transformações políticas que marcaram profundamente a vida nacional. É nessa época que surge em São Paulo o Ballet Stagium, em 1971, companhia que viria a modificar inteiramente o cenário brasileiro da dança. Para entender a sua importância, vale lembrar do contexto sócio-político no qual nasce.

Dia $1^{\circ}$ de abril de 1964 , os militares tomam o poder através de um golpe, mas como destaca Zuenir Ventura no artigo intitulado $O$ Vazio Cultural, publicado na Revista Visão:

Mais do que a Revolução de 1964, com todas as transformações que provocou no País no momento de sua implantação, foi o Ato Institucional de n. ${ }^{5}$, que viria transformar radicalmente a cultura brasileira, através de uma implacável ação que se exerceu em dois planos. Com a censura prévia agindo no interior do campo cultural - cortando, expurgando ou simplesmente vetando --, pôde exercer-se um rigoroso trabalho de prevenção; com os outros poderes que transcendem a cultura - cassação, expulsão, aposentadoria e prisão - , pôde instaurar-se um inapelável mecanismo de punição. (VENTURA, 2000, p.43). 
Também é interessante notar no artigo de Zuenir Ventura a menção que ele faz a questão do público:

Em primeiro lugar, a existência no Brasil -- pelo menos em suas grandes cidades e em algumas faixas da população - de um público relativamente amplo que já não pode deixar de consumir regularmente cultura, ou seja: ir ao cinema ou ao teatro, ler livros, manter-se informado etc. Em segundo lugar, a existência de uma estrutura de produção cultural (empresários teatrais, editores, produtores de cinema, etc.) que mantém em funcionamento as atividades intelectuais e não poderia ser desmontada sem graves consequiências inclusive para a economia. (VENTURA, 2000, p.48).

Diante do cenário descrito por Zuenir, os artistas buscavam seu espaço, em especial popularidade, em outras palavras, basicamente formação de um público fiel, além de meios para transmitir suas idéias. Como afirma Marcos Napolitano em seu texto A Arte Engajada e seus públicos (1955-1968):

(...) o espaço de atuação privilegiado do artista/intelectual de esquerda não foi a prosa ou o ensaio, embora os anos 50 e 60 fosse pródigos também nesses gêneros, mas as artes que apelavam para os sentidos corpóreos, através de imagens, sons e ritmos." (Napolitano, 2001,p.9)

Para Zuenir Ventura, a cultura seguiu em três direções:

uma cultura de massa digestiva, comercial, de simples entretenimento; uma contracultura buscando nos subterrâneos do consumo, mas freqüentemente sendo absorvida por este, formas novas de expressão e sobrevivência e uma cultura explicitamente crítica, tentando olhar para a realidade política e social imediata. (VENTURA, 2000, p.51). 
Ventura observa o crescimento, no período, do chamado setor digestivo, com o aumento de bilheteria para comédias eróticas ou livros traduzidos. No entanto, alguns setores não viram esse crescimento, como foi o caso do teatro. Com a forte censura e restrições ao repertório, diminuíram o número de platéia. Para Marcos Napolitano, esse fenômeno está ligado também ao fato do teatro se voltar contra o público:

tendo como paradigmas as peças $O$ Rei da Vela e Roda-Viva, do Grupo Oficina, não por acaso exemplo de teatro agressão. (...) a implosão ideológica do público teatral e sua expressão cênica acabarão por afastar, momentaneamente, a própria presença de extratos mais amplos da classe média (ou 'pequena burguesia') das platéias. Obviamente não podemos esquecer a violenta censura e repressão que se abateu sobre o meio teatral a partir do AI-5 (...), processo que dificultava a montagem de qualquer peça mais crítica. A crise de público, tão discutida no início dos anos 70, revela não só uma mudança estrutural da platéia de teatro, mas também a própria crise da fundação política do drama, exercitada desde os anos 50 e vivida sob a égide da 'emoção-consciência-resistência-cartase. (NAPOLITANO, 2001,p.8)

Mais um dado para compreender melhor o contexto do início dos anos 70: a questão da formação de uma cultura nacional. No texto retirado do livro Ideologia da Cultura Brasileira, o professor Carlos Guilherme Mota referindo ao ensaio Vanguarda e Subdesenvolvimento, de Ferreira Gullar escreve:

desde as primeiras manifestações do romantismo até os dias em que escrevia, Ferreira Gullar elabora um 'discurso' onde, com certa habilidade, conseguirá integrar textos tão desiguais quanto os de Marx e Antonio Candido, e de Nelson Werneck Sodré e Pedro Calmon - tentando estabelecer o surgimento da temática do nacionalismo. (...) O autor está preocupado em estabelecer 'um ponto de referência para a definição de uma cultura brasileira': Não se trata, evidentemente, de uma cultura própria, especificamente nacional, mas cultura 
brasileira no sentido de aglutinação dinâmica de elemento reelaborados que, através de décadas, se mantêm ligados e ativos numa interação capaz de responder ao presente e ajudar na sua formulação.” (MOTA, 1994, p. 230, 231)

\section{Como destaca Alfredo Bosi:}

Se nos ativermos fielmente à concepção antropológica do termo cultura, que é, de longe, a mais fecunda, logo perceberemos que um sem-número de fenômenos simbólicos pelos quais se exprime a vida brasileira tem a sua gênese no coração dessa vida, que é o imaginário do povo formalizado de tantos modos diversos, que vão do rito indígena ao candomblé, do samba-de-roda à festa do Divino, das Assembléias pentecostais à tenda de umbanda, sem esquecer as manifestações de piedade do catolicismo que compreende estilos rústicos e estilos cultos de expressão" (BOSI, 1992, p. 322).

É interessante notar que nesse período intelectuais e artistas voltamse para o folclore como uma maneira de resgatar as origens da cultura brasileira.

A vertente romântico-nacionalista, ou romântico-regionalista, ou românticopopulista (os matizes mudam conforme a conjuntura) toma por valores eternamente válidos os transmitidos pelo folclore, ignora ou recusa as suas vinculações com a cultura de massa e a cultura erudita, e identifica as expressões grupais com um mítico espírito do povo, ou mais ideologicamente, com a Nação, fazendo pender para um excessivo particularismo o que, na concepção oposta, se perdia num abstrato universalismo." (BOSI, 1992, p 324).

O professor-conferencista de Sociologia da London School of Economics and Political Science, Alan Singewood, destaca em seu livro $O$ Mito da Cultura de Massa: o termo 'indústria da cultura', empregado pela primeira vez em Dialetic of Enlightenment, de Horkheimer e Adorno (1944), durante seus anos de exílio nos Estados Unidos no período em que a Alemanha vivia sob o regime nazista, visou claramente a sugerir o 
domínio de cima, embora seu sucesso ainda dependesse de uma classe operária amorfa, passiva e irracional. Os meios de comunicação em massa são repressivos: sufoca-se a crítica ao capitalismo, a felicidade é identificada com a aquiescência e com a completa integração do indivíduo na ordem social e política existente. Dois termos dominam na teoria de sociedade de massa da Escola de Frankfurt: a fraqueza das instituições socializadoras tradicionais diante da mudança econômica e tecnológica maciça; a crescente reificação da cultura, onde os objetos de trabalho e da atividade do homem se transformam em forças independentes, autônomas, aparentemente fora do controle humano. O homem atomizado da sociedade de massa é governado, então, pela 'necessidade cega'. Na verdade para Horkheimer e Adorno, o sistema econômico do capitalismo moderno tornou-se uma força auto-reguladora, dominada por leis econômicas e tecnológicas inevitáveis. A sociedade moderna, escreve Horkheimer, destrói todo vestígio da autonomia dos indivíduos enquanto caminha para 'um mundo automático, racionalizado, totalmente administrado'. Escrevendo numa época (os anos trinta) em que parecia iminente o colapso final da democracia capitalista liberal, não como Marx havia previsto, mas com base nas forças combinadas da política totalitarista (o fascismo) e da economia totalitarista (o crescimento de monopólios e cartéis gigantescos e a fusão do capital bancário e industrial), os teóricos de Frankfurt convenceram-se de que a evolução do capitalismo precisava da destruição daquelas instituições sociais - econômicas, políticas e legais - que, agindo como mediadoras entre Estado e a 'sociedade civil', tinham continuado elasticamente independentes, dando alguma proteção, se bem que parcial, contra a dominação política arbitrária. O fascismo destruiu a sociedade civil; toda instituição foi politizada. Com efeito, Adorno e Horkheimer generalizaram, partindo do desenvolvimento específico do fascismo alemão, para o capitalismo como um todo, argumentando que a 'indústria 
da cultura' americana (um conceito que preferiam ao de 'cultura de massa', com suas sugestões de origem espontânea dentro das massas) desempenhou as mesmas funções que o Estado fascista. (SINGEWOOD, 1978, p.14 e $15)$.

Sobre a arte, Singewood destaca a visão da Escola de Frankfurt da seguinte forma:

Os produtos da cultura de massa, pelo fato de terem que apelar para um público grande e homogêneo, não dão margem à imaginação. São um 'empobrecimento da questão estética', o que, longe de envolver o leitor numa dialética verdadeira, concebem-no como um objeto passivo a ser manipulado e controlado. No mundo da fantasia dos meios de comunicação de massa, a cultura se funde com a diversão: a arte de massa é 'um chafurdar cego em fantasias e desejos' que frustram, obrigatoriamente, uma vida emocional normal e educam as massas para a obediência. Os teóricos de Frankfurt concluem elogiando a cultura 'consciente e ativa' da classe média do século 19 , em contraste com a "vida quase toda inconsciente e passiva' da classe média das massas modernas, organizadas. A arte torna-se uma mercadoria desprovida de qualquer autonomia real, já que funciona não só para melhorar o mundo de trabalho alienante, como também como uma forma de integração social depois da desintegração da família. Em Dialectic of Enlightenmente, Horkheimer e Adorno argumentam que a 'arte renuncia à sua própria autonomia e toma, orgulhosamente, seu lugar entre os bens de consumo... comercializáveis e substituíveis como um produto industrial' (...) A indústria da cultura produz, necessariamente, uma forma de arte dominada por uma 'harmonia pré-estabelecida', a ausência da tragédia e a eliminação dos elementos negativos. O 'barbarismo estético', escrevem Horkheimer e Adorno, passa a ser a essência da arte capitalista moderna, exigindo de seus súditos 'obediência à hierarquia social'. Adorno conclui que o capitalismo reduz o indivíduo a um mero agente das tendências sociais objetivas; só quando a obra de um artista não é mais 'adaptada ao consumo imediato, 
quando ela se levanta contra a sociedade, é que ela assume um significado'. (SINGEWOOD, 1978, p.17)

Nesse contexto surgem a dança e o balé moderno em São Paulo. Ambos, nos anos 70, ganharam certo reconhecimento do público brasileiro, sobretudo o balé moderno. Até mais que o teatro, com seus atores amordaçados pela ditadura militar, bailarinos tornaram-se porta-vozes da crítica situação nacional. São Paulo viu nascer o Balé Stagium, em 1971, um marco do que se transformaria em uma nova tendência artística. A companhia de Marika Gidali e Décio Otero traduzia por meio de movimentos e gestos, discussões sociais e políticas. A dança passava a buscar um relacionamento mais direto com o público.

O Stagium manteve os passos do balé, mas a concepção dos espetáculos que passou a produzir era absolutamente diferente do de um balé tradicional. Seu objetivo era desenvolver um tipo de dança que se parecesse com o Brasil e que, ao mesmo tempo, pudesse ser compreendida por pessoas que jamais tivessem tido contato com qualquer tipo de dança. A companhia partia da cultura nacional para criar seus espetáculos como, por exemplo, Diadorim, coreografia baseada no romance Grande Sertão Veredas, de Guimarães Rosa.

Ao longo da década, o Stagium tornou-se a primeira companhia de dança a percorrer todo o Brasil, a proposta estava em levar a dança aos brasileiros. Suas apresentações poderiam ocorrer em praças públicas, teatros, igrejas, favelas, escolas ou clubes e em locais com realidades sociais completamente diferentes como a Serra Pelada, as vilas próximas ao Rio São Francisco, o Parque Nacional do Xingu e a Avenida Paulista. Os diretores do Balé Stagium, Décio Otero e Marika Gidali, faziam dos 
assuntos relevantes, tanto para o Brasil, como na América Latina, a sua temática coreográfica: censura, violência, massacres, direitos humanos, seca, miséria, preconceito racial, sexual, amoroso, social, religioso e ecologia.

O Stagium se tornou um fotógrafo de realidades, fazendo da sua ação, nos anos 70, a voz dos que resistiam. (...) Foram eles os inventores dessa maneira de dançar temas seqüestrados da cidadania, numa ponte entre o teatro e a rua”. (KATZ, 1994, p.32).

Desse elo nasceram, entre vários outros sucessos, Das Terras de Benvirá, ao som de Geraldo Vandré, os inconfidentes estavam presentes em Dona Maria I (1974), aos aviltamentos humanos em Quebradas do Mundaréu (1975), metáforas da liberdade em Danças das Cabeças (1978) ou do romantismo brejeiro em Valsas e Serestas (1979).

No início dos anos 70, vários outros grupos se formam. Em torno da técnica de Martha Graham, em 1973, nasceu o Grupo Experimental de Dança (GED), dirigido por Penha de Souza, uma das professoras pioneiras no ensino dessa técnica no Brasil. Outros artistas e grupos surgiram distantes do balé como Célia Gouvêa, que estreou em 1974 o espetáculo Caminhada, ao lado do marido, Maurice Vaneau, no Teatro Galpão. Ruth Rachou também trabalhava com a técnica de Marta Graham e apresentou em 1975 o espetáculo Auké, no Galpão.

Os trabalhos de Célia Gouvêa e Vaneau traziam o que hoje se chama de 'experiência de linguagem' - e que Célia prefere chamar de 'dança teatral' que, ao primeiro contato, causaram certa estranheza. Em Caminhada, Célia veio com seqüências de movimento que se afastavam do comum da dança, livre ou acadêmica, que, no entanto, criavam uma organização espacial, um tempo 
próprio e um impacto auditivo, diferentes dos padrões estéticos da dança paulista.” (DIAS, NAVAS, 1992, p. 134)

A partir de 1974, o Corpo de Baile do Teatro Municipal deixa de lado as fadas e volta à cena, primeiramente com Lia Marques e, depois, sob o comando de Antonio Carlos Cardoso, que promoveu uma mudança de rumos tão profunda ao arejar o elenco e fugir do conservadorismo existente, que acabou resultando, em 1981 na troca do nome da companhia para Balé da Cidade de São Paulo.

Klauss Vianna recebeu o prêmio Moliére pela preparação corporal dos atores da peça teatral Roda Viva. Klauss e Angel Vianna, desde os anos 50, já desenvolviam técnicas próprias e estudos sobre o corpo e a dança.

A produção na dança cresce. No ano de 1975, destaca-se Auké, de Ruth Rachou, um espetáculo sem música, com a participação do ginasta olímpico João Maurício, que anos depois se destacaria na companhia norteamericana de Paul Taylor, em Nova York. Ruth Rachou cria também Dança dos Pássaros. Ruth Rachou foi uma das responsáveis por introduzir no Brasil as idéias e técnicas de Marta Graham.

Auké, da dupla Rachou-Medeiros, onde se mostrava pela primeira vez o ginasta olímpico João Maurício, tornado bailarino (hoje uma das principais figuras da companhia de Paul Taylor, em Nova York), resultava um trabalho involuntariamente mais tradicional, inspirado em uma lenda indígena e utilizando as técnicas da modern dance - isto é, uma dança moderna com data baseada em Martha Graham, às vezes com ênfase até didática, mas sempre dentro de uma impecável execução, da qual participaram ainda bailarinos como Thales Pan Chacon - sua estréia no Galpão, onde depois se apresentaria tantas 
vezes - Yetta Hansen, Debby Growald, Zina Filler e Paulo Contier. (DIAS, NAVAS, 1992, p. 136)

Ainda neste ano, J.C. Violla fez a preparação corporal de Falso Brilhante, o famoso show de Elis Regina, e Célia Gouvêa dançou Pulsações. No ano seguinte, o Grupo Corpo, de Minas Gerais apresenta Maria, Maria, coreografia de Oscar Araiz com trilha de Milton Nascimento, que bateria todos os recordes de longevidade, continuando a ser dançada nos nove anos seguintes. Embora situado em Belo Horizonte, é da mesma natureza da dança que o Stagium fazia o início do Grupo Corpo. Maria, Maria pertence à uma linhagem de trabalhos apoiados no balé para falar de uma situação brasileira que o Stagium estava desenvolvendo.

Em 1977, o Corpo de Baile do Municipal ganha sede própria e nasce a companhia Cisne Negro. O ano seguinte, 1978, foi expressivo para a dança. Bailarinos e coreógrafos se reuniram na primeira Comissão de Dança no Brasil, que promoveu um ciclo de filmes sobre dança no Museu da Imagem e do Som, um festival de dança e jazz no Museu de Arte de São Paulo e a criação do espaço da dança no prédio da Bienal. Surge o grupo Andança, de Lia Rodrigues, Sônia Galvão, Malu Gonçalves e Sílvia Bittencourt, um grupo com direção artística coletiva. J.C. Violla e Janice Vieira apresentam Senhores das Sombras, Últimos Santos e Oscar Araiz coreografa Cenas de Família para o Corpo de Baile.

Em uma década de efervescência se destacaram os coreógrafos: Ana Maria Mondini, Victor Navarro, Oscar Araiz, Luis Arrieta, Ademar Dornelles, Maria Duschenes, Takao Kusuno, Denilto Gomes, Mara Borba, Ivaldo Bertazzo. No Rio, surgiram o Grupo Coringa, de Graziela Figueroa, e o Teatro do Movimento, de José Possi Neto. Na Bahia, Estado que viu 
nascer o primeiro curso de nível superior em dança, na Universidade Federal da Bahia (1956), promovia Arte Bahia, um festival que apresentava os principais grupos e artistas do País, as discussões que envolviam o processo de criação artística, assim como temas pertinentes à sobrevivência e manutenção de companhias e artistas, uma vez que não havia interesse estatal ou apoio financeiro para esta arte. 


\section{Capítulo 2: O Balé Stagium}

O objetivo deste capítulo é refletir sobre o papel do Balé Stagium no desenvolvimento da dança brasileira, de 1971, ano da sua criação, até 1979, quando é assinada a anistia política no Brasil. No decorrer deste texto procuro tratar das questões políticas que envolvem a cultura, a presença da censura, principalmente a forte repressão a partir do governo do presidente Emílio Garrastazu Médici e da instituição do Ato Institucional número 5 (AI-5) em 1968.

A ênfase dada mesmo é ao significado revolucionário do trabalho do Balé Stagium, um dos responsáveis por introduzir a dança brasileira no universo da brasilidade. Mais do que isto, o Stagium abandonou a visão nacionalista presente nas criações que havia neste segmento cultural baseadas na interpretação do folclore brasileiro. A companhia deixa de lado as iaras e os uirapurus para discutir temas em voga na época, como a censura e a opressão entre outros assuntos seqüestrados da cidadania. A companhia saiu dos palcos dos grandes teatros e percorreu todos os cantos do Brasil para levar a sua dança.

A hipótese deste capítulo é mostrar o Balé Stagium como uma companhia de balé moderno. Um grupo capaz de romper com a temática dominante do período, com as histórias de amor do balé clássico. Décio Otero e Marika Gidali estabelecem um diálogo com o público, assim como com a música popular e erudita, com a literatura e artes plásticas aplicando o modelo inventado por Diaghilev e, depois, aperfeiçoado por Maurice Béjart. 
Mesmo sem romper com a técnica do balé, o grupo busca uma linguagem própria, acessível e que ao mesmo tempo discuta assuntos pertinentes aos brasileiros. O público deixa de ser um observador passivo e se torna parte do espetáculo. O Stagium nega a dança decorativa e busca discutir questões próximas à realidade dos homens e nos anos da década de 70 procurou denunciar a situação do país em uma época silenciada pela ditadura militar.

\section{A História do Balé Stagium}

A história do Balé Stagium começa com a parceira entre a bailarina Marika Gidali e o coreógrafo e bailarino Décio Otero ${ }^{3}$. Marika nasceu em 1936 em Budapeste, capital da Hungria. Filha da costureira Erzsébet (Elizabeth) e do alfaiate Bela Gidali, em um lar judeu, Marika sofreu desde muito cedo com as agruras e horrores da Segunda Guerra Mundial, principalmente o anti-semitismo.

Durante a guerra, os pais de Marika foram presos, ela e a irmã mais velha foram obrigadas a morar no porão do prédio em que viviam com a família. Depois fugiram para um orfanato da Cruz Vermelha, na mesma rua. E diante das terríveis condições de vida no orfanato decidiram voltar a morar no porão do prédio.

\footnotetext{
${ }^{3}$ Décio Otero (1933 -) Nasceu em Ubá, Minas Gerais. Bailarino, coreógrafor, professor e diretor, estudou com Carlos Leite e fez sua estréia profissional dançando O Espectro da Rosa. Ingressou no Balé do Teatro Municipal do Rio de Janeiro em 1956 e chegou ao posto de primeiro bailarino. Em 1959 percorreu o Brasil dançando com Margot Fonteyn e Michel Sommes o balé Gisele. Em 1964 ingressou no Grand Theatre de Geneve, na Suíça. Em 1966 ingressou na Ópera de Colônia, na Alemanha. Em 1967 transfere-se para o Balé de Frankfurt como primeiro bailarino.Em 1970 retorna ao Brasil e em 1971, ao lado de Marika Gidali, funda o Balé Stagium.
} 
Quando a mãe, Elizabeth, conseguiu escapar dos nazistas, levou as meninas com ela para um gueto de judeus na cidade de Peste. As condições não eram boas. Ali não havia cama tampouco comida. Todos que ali estavam passavam frio e fome. Marika conseguia pegar lentilhas secas e comia escondido alguns grãos como relata Décio Otero no livro Marika Gidali Singular e Plural. Essa situação durou até 1945, quando as tropas russas chegaram à Hungria.

Após a vinda dos russos, mãe e filhas puderam voltar para o apartamento onde moravam. O pai voltou para casa dias depois. A família decidiu mudar de país e em 1946 desembarcava no Brasil.

Marika começou sua carreira como bailarina no clube Húngaro, depois ingressou no Balé do IV Centenário, sob a direção de Aurélio Milloss em 1954. Com o fim da companhia em 1956 atuou no Corpo de Baile do Teatro Municipal do Rio de Janeiro, onde teve oportunidade de trabalhar com o coreógrafo Leonide Massine. Nessa época pôde assistir ao espetáculo Sinfonia para um Homem Só de Maurice Béjart. Duas influências que marcaram profundamente a sua carreira, tanto que Marika tentará seguir os passos de Béjart no futuro, na criação e atuação do Stagium.

Em 1957 a bailarina profissional abandonou a segurança de funcionária pública e voltou para São Paulo com o intuito de atuar no Balé do Teatro Cultura Artística. Sem verbas e sem apoio o grupo não durou muito chegando ao fim em 1959.

Sem lugar para ensaiar, Marika abriu então sua primeira escola na esquina das Avenidas Duque de Caxias e São João, em sociedade com Neyde Rossi. Ao 
mesmo tempo assumiu sozinha as coreografias para a tevê, com plena aprovação do empresário Abelardo Figueiredo, e realizou seu primeiro trabalho de fôlego nesse gênero, Orfeu do Carnaval, em parceria com Ruth Rachou (OTERO, 2001, p.69).

Na década de 60 Marika trabalharia no Balé de Câmara criado por Marilena Ansaldi. Além das atividades para a televisão, a bailarina abriu uma nova escola na Rua Sarandi, no bairro dos Jardins em São Paulo, em 1964, ano em que o País mergulhava na ditadura militar. Período em que atuou com o grupo Afirmação e com o diretor de teatro Ademar Guerra. Nessa década ela conheceu Décio Otero. Da união dos dois nasceria o Balé Stagium.

São Paulo viu surgir o Balé Stagium, em 1971, uma companhia que emergia das salas de aula de uma escola, sob o comando de Marika Gidali e Décio Otero. Alguns bailarinos, sem verbas, ficavam alojados em uma casa que Marika possuía em Osasco. Eles vinham diariamente para as aulas da companhia na Rua Sarandi. Dançavam sem recursos ou aporte financeiro do Estado. Os intérpretes trabalhavam em cooperativa e o que os movia eram os sonhos, não propriamente os recursos financeiros. Eles buscavam a formação de público para um estilo até então pouco comum de dança, que fugia os contos de fadas do balé.

Viver em cooperativa significava repartir entre os membros da companhia os produtos dos espetáculos. Em um primeiro momento, por falta de espaço e condições, cinco bailarinos do grupo foram alocados em uma casa em Osasco, que pertencia a Marika Gidali. Ali eles se revezavam em atividades domésticas como os cuidados com a limpeza e comida. 
O Stagium foi convidado para apresentar uma série composta por espetáculo chamada Convite à Dança, exibida pela TV Cultura, em 1971.

A companhia realizou seis programas diferentes, de 25 minutos de duração cada um, para a emissora estatal. O grupo mostrou diversos estilos de dança: clássico, neoclássico, moderno e dança-teatro. A primeira parte do programa consistia em uma explicação didática e a segunda, a apresentação de uma coreografia inédita sob o tema proposto. A narração dos textos ficou a cargo de Armando Bogus, Sérgio Viotti, Maria Izabel de Lisandra, Eva Wilma e Karim Rodrigues. A direção era de Irineu di Carli. Para a criação coreográfica foram convidados: Addy Ador, Marilena Ansaldi, Ismael Guiser, Jerry Maretsky, Clarisse Abujamra e Ruth Rachou. O elenco era composto por: Geralda Araújo, Marina Helou, Milton Carneiro, Ivaldo Bertazzo, Donato Chiarella, Marika Gidali e Décio Otero.

Com o cachê da apresentação do programa para a TV Cultura, os intérpretes puderam mudar para pensões próximas à sede da companhia, na capital. Ali, os artistas ensaiavam diariamente das $9 \mathrm{~h}$ às $14 \mathrm{~h} 30 \mathrm{e}$ das $19 \mathrm{~h}$ às $22 \mathrm{~h}$.

O Balé Stagium estreou em Santos, no Teatro Independência, em 23 de outubro de 1971, para uma platéia composta por 20 pessoas. E no dia 13 de dezembro a companhia fez sua estréia em São Paulo, no Teatro São Pedro.

O Stagium nasceu durante os anos mais autoritários de um golpe militar que perseguia e torturava estudantes, trabalhadores, a Igreja e os políticos do Brasil. Era o governo Médici, com o AI-5, censura e crescimento econômico acompanhado de uma perversa distribuição de renda. Brasil tricampeão de 
futebol, pátria do infeliz 'ame-o ou deixe-o', com Marighela (1969) e Lamarca (1971) assassinados. Nesse ano Marika Gidali e Décio Otero fundam o Stagium - provavelmente sem imaginar que ainda na sua aurora estabeleciam o marco mais importante da dança da década." (KATZ, 1994, p. 14).

\section{E Décio Otero afirma:}

Em 1971, a criação coreográfica brasileira era uma cópia pálida das fadas e príncipes mal-importados da Europa e dos Estados Unidos, e nossa originalidade foi olhada com espanto.” (OTERO, 1999, p. 21).

O primeiro espetáculo criado pelo grupo foi Orfeu e Eurídice, criação de Marika Gidali e Décio Otero. Este assinou a composição de mais duas coreografias no mesmo ano: Dessincronias e Impressions. Sem recursos financeiros o grupo deixou de lado os adereços, cenários e brilhos. Dançavam com um figurino simples, apenas trajavam malhas.

Nossa única certeza recaía na disposição de abraçar temáticas brasileiras sem priorizar estilos de dança. Adotamos uma linha de trabalho derivada de um pensamento claro a respeito do homem. (OTERO, 2001, p.99).

Para encontrar essas temáticas o grupo optou por percorrer o Brasil. "Era o momento de fazer o que foi feito, viajando, perceber a pluralidade e a diversidade de expressões musicais e danças de que não se tinha notícia." (OTERO, 2001, p. 100).

Nos meses de janeiro e fevereiro de 1972, os artistas aventureiros viajaram em um ônibus leito por Estados do Norte e Nordeste do País. O ônibus foi oferecido pela Secretaria de Cultura, Esportes e Turismo do Estado de São Paulo. E o Stagium mostrava-se como uma verdadeira 
companhia mambembe. O grupo só se hospedava em um hotel quando tinha hospedagem paga, caso contrário, dormia no próprio veículo. Quando a situação financeira da companhia tornava-se preocupante, a ajuda vinha da escola, que entre seus professores contava com nomes importantes da dança como Ivaldo Bertazzo e Liliane Benevento.

Foi neste ano, em 1972, que Décio Otero criaria a coreografia Diadorim inspirada no livro Grande Sertão: Veredas, de Guimarães Rosa. "Diadorim abriria nosso enfoque de temas nacionais, criando uma identidade que repercutia favoravelmente no País e na América Latina." (OTERO, 2001, p. 103). Neste ano a companhia também montou Entrelinhas e Episódios. Ano que marcou o início de uma carreira internacional, a companhia se apresentou no Teatro Coliseu de Bueno Aires, na Argentina.

No ano de 1974, o Stagium levou ao palco uma crítica à repressão e à censura que a ditadura militar impunha ao País - a coreografia Dona Maria I, a Rainha Louca. O ponto de partida está no Romanceiro da Inconfidência, de Cecília Meirelles. A direção foi de Ademar Guerra, que deu um caráter dramático e teatral ao espetáculo. A trilha sonora incluía músicas de Marlos Nobre, Geraldo Vandré, Edu Lobo e Villa-Lobos. A estréia foi no Rio, na sala Cecília Meirelles.

Outra apresentação importante neste ano foi Jerusalém, com trilha sonora de José Antonio de Almeida Prado. A música foi composta para a Filarmônica de Genebra e foi apresentada pela primeira vez no Brasil com o Stagium. Uma trilha sonora que remete à música sacra, cantada em latim, aborda o sofrimento das três Marias aos pés da cruz de Cristo. Em cada lugar onde é apresentada a composição, um narrador fala a seqüência do 
Evangelho, na língua oficial do país, sobre a paixão de Jesus. O acompanhamento musical é feito com percussão.

Nesta peça, a idéia é de que todos os intérpretes são cristos, que morrem e ressuscitam no final. A ressurreição seria uma metáfora da esperança, de uma nova vida diante da repressão imposta pelo regime militar. "A escrita coreográfica era moderna. Os cenários feitos de sacos de estopa e as malhas beges eram manchadas de marrom, manchas estas que subiam por nosso pescoço e rosto." (OTERO, 1999, p.137).

Mesmo debatendo assuntos delicados, os censores a serviço da ditadura militar não importunavam o Stagium. Eles se preocupavam muito mais com os corpos nus ou algo que considerassem uma afronta a moral e aos bons costumes. Em 1976 Marika Gidali e Décio Otero foram chamados a comparecer à Polícia Federal na Rua Piauí. "Havíamos tirado visto em Paris para visitar os parentes dela (Marika) na Hungria. O entrevistador acreditava que éramos 'pombos-correio' internacionais empenhados em levar informações secretas a países comunistas." (OTERO, 1999, p.67). Desfeito o mal-entendido a dupla seguiu com sua dança. Os censores não viam na dança, mesmo com as andanças do Stagium pelo Brasil e os temas abordados, como uma possível ameaça.

O ex-bailarino do Balé do $4^{\circ}$ Centenário e professor de balé da Companhia de Maurice Béjart, Cristian Uboldi, foi convidado para montar Psiculumspeculu, com músicas de Pink Floyd, cenários e figurinos de Darcy Penteado. A inspiração para o espetáculo veio do verso do poeta norte-americano Walt Whitmann: "Quantas vezes indago e ponho em dúvida que isso seja realmente eu". O Jornal da Tarde de 22 de maio de 1974 publicou: 
Dois espelhos são personagens importantes da história, um está disposto na frente do outro - ilusão de ótica de um corredor e sugere multiplicidade de objetos. Um casal - Marika e Décio - propõe-se sair de uma determinada engrenagem - mostram-se os valores falsos de uma sociedade. Outro casal Geralda Bezerra e Milton Carneiro - faz tudo para que não dê certo a libertação do par primitivo. Essa luta é uma pesquisa para misturar dança e teatro.

Neste ano, o grupo de Décio Otero e Marika Gidali assinou um contrato com o Departamento de Cultura da Prefeitura de São Paulo, para realizar doze espetáculos: duas apresentações no Teatro Arthur Azevedo, duas no Teatro Paulo Eiró, duas no Teatro Municipal e uma apresentação no Parque do Ibirapuera.

O ápice das críticas ao regime político brasileiro veio com Quebradas de Mundaréu uma adaptação do texto Navalha na Carne, de Plínio Marcos, autor considerado subversivo e perseguido pelos censores, em 1975. "Pensamos em um grupo artístico que se preocupasse com idéias. Primeiro o que dizer; depois, o que dançar”, diz Décio Otero (Otero, Décio. Stagium as Paixões da Dança, Senac, 2001). O próprio Plínio Marcos escreveu em 1998 para a revista Caros Amigos sobre a versão do Stagium para a sua peça:

“(...) Todos demonstraram uma coragem imensa. Mas uma delas, uma das maiores artistas do Brasil, se destaca pelo atrevimento típico dos gênios. De repente, no auge da ditadura, Marika Gidali resolveu montar Navalha na Carne. No Teatro Municipal de São Paulo!

Mudou o nome da peça para Quebradas de Mundaréu, enganando a censura. E, ao lado dela Décio Otero e Milton Carneiro, entrou na pele de Neusa Sueli. Sem uma palavra, só dançando com uma força, com aquela energia que penetra todas 
as coisas, ela fazia todo o teatro, lotadinho, perceber que Neusa Sueli, a prostituta degradada, estava viva. Que Plínio Marcos não tinha se apagado.”

Neste mesmo ano, 1975, a companhia dançaria Entrelinhas e D. Maria I, a Rainha Louca no Teatro Galpão. A Sala Galpão do Teatro Ruth Escobar se tornaria um espaço voltado para a dança, onde artistas tinham a liberdade de apresentar espetáculos experimentais. Um espaço voltado para a reunião e difusão de novos talentos.

No ano da morte dos presidentes Juscelino Kubitscheky e João Goulart, em 1976, Décio Otero criou Resquícios, Das Terras de Benvirá, e ao lado de Marika Gidali compôs Bamboleô.

Se Diadorim falava do Sertão as Gerais com balé, Kuarup (1977) propunha algo diverso: procurava construir a partir da estrutura de movimento dos índios, e não apenas através da incorporação do seu gestual.” (KATZ, 1994, p.44)

Kuarup ou a Questão do Índio, de 1977, Décio Otero decidiu criar uma coreografia que discutisse o genocídio dos índios.

Minha preocupação era abordar um tema tão difícil sem cair na mesmice de experiências passadas, quando dançava em óperas e mesmo nos diversos balés que enfocavam esse tema. Não queria índios vestidos como certos cantores e bailarinos trajando malhas cor de ferrugem enrugadas pelo corpo, imitando a pele avermelhada dos indígenas. Tinha verdadeiro horror aos estereótipos dos cartões postais turísticos sobre nossos índios. (OTERO, 1999, p.139).

A partir de músicas de índios do alto e baixo Xingu, coletadas pelos irmãos Villas-Boas na década de 50, Décio Otero e Marika Gidali seguiram para o estúdio. 
Pesquisei o gestual do índio, suas crenças e cerimônias religiosas e suas danças, com múltiplas conotações sociológicas, mitológicas e religiosas. No gestual de Kuarup não foi utilizado nenhum passo acadêmico de escolas clássicas ou modernas. (OTERO, 1999, p. 140).

Para o Stagium não fazia sentido usar uma linguagem importada para tratar de um assunto tão brasileiro. Tampouco fazia sentido tentar recriar a dança dos índios. A coreografia partiu de uma linguagem coreográfica simples para um debate mais sofisticado.

Na obra não deveria enfocar somente a sociedade indígena, mas todas as outras sociedades. De uma forma ou de outra, todos estamos sendo dizimados pelas guerras ideológicas, as guerras religiosas, a poluição dos grandes centros e as guerras bacteriológicas. Não seriam índios. Seriam trabalhadores dos centros urbanos lutando pela sobrevivência. (OTERO, 1999, p. 140).

Bailarinos dançavam com um figurino peculiar: macacões verde e amarelo, vestidos como operários. Somente no final do espetáculo transformavam-se em índios para celebrar a dança da morte.

Décio coreografou Dança das Cabeças em 1978 com música de Egberto Gismonti, que empresta o nome ao espetáculo, e de Mikis Teodoraks inspirado nas poesias de Pablo Neruda e no ano de 1979 Coisas do Brasil e Valsas e Serestas.

Ao criar o balé Dança das Cabeças incluímos nele músicas e imagens das comunidades carentes que tanto impressionaram (durante a trajetória na barca dos sonhos). Queríamos retratar o desespero e o sofrimento de um Brasil abandonado, esquecido. A viagem ao coração deste Brasil que já conhecíamos. Assim modificou-se nossa temática e em 1975 encenamos Navalha na Carne, de 
Plínio Marcos, escritor que a censura de então considerava altamente subversivo. (OTERO, 2001,p.112)

\section{Na estrada}

O Balé Stagium se caracterizou por ser uma companhia bambembe, que rodou pelo Brasil e exterior. Dois momentos foram marcantes para o grupo: a Barca da Cultura e a visita aos índios do Xingu.

A ação inicial do Stagium foi produzir para os que estavam fora do circuito oficial do balé. Abriu uma via e, em seguida, pavimentou o acesso para que a sua dança chegasse até os desabrigados da arte, os que não freqüentavam teatros nem faziam assinaturas de temporadas. Uma depois da outra, suas coreografias foram definindo uma estética para os assuntos do cotidiano, em língua de balé. Um jeito de falar sem gravata nem terno, com uma preocupação básica: ser acessível e descomplicado para ajudar a construir seres humanos melhores." (KATZ, 1994, p.34).

A Barca da Cultura ou Barca dos Sonhos, como também era conhecida, foi idealizada por Pascoal Carlos Magno, em 1974. O projeto consistia em levar 150 artistas entre bailarinos, músicos, atores e artistas circenses para se apresentarem em cidades à beira do Rio São Francisco. O grupo partiu da cidade de Pirapora, em Minas Gerais, e seguiu até Juazeiro, na Bahia. Além do Balé Stagium, participaram os músicos da Orquestra Jovem do Teatro Municipal de São Paulo, os artistas do Teatro da Universidade Federal de Juiz de Fora, o grupo Teatro do Estudante do Paraná, o maestro Carlos Eduardo Prates, na época regente da Filarmônica de Berlim, entre outros artistas que navegaram por 15 dias na barca. 
A barca ia atracando nos 'portos' dos vilarejos e, enquanto o Stagium dançava no cimento da praça pública, os atores armavam tenda em outros espaços e os músicos valiam-se dos degraus de igrejas ou do que mais encontrassem. Levavase uma insólita surpresa para os ribeirinhos mergulhados em precariedades, oprimidos na espera de que lhes viessem avisar que sua casa seria alagada por uma hidrelétrica em construção.” (OTERO, 2001,p.108).

A barca percorreu cidades como Xique-Xique, Morpará, Bom Jesus da Lapa, Remanso, Manga, Carinhanha, Ibotirama e Casa Nova. Nos lugares onde a energia elétrica não havia chegado, os artistas se apresentavam em um tablado montado no convés da própria barca.

Outra experiência marcante para a companhia e arrojada para a época foi a viagem ao alto Xingu em 1977, quando o grupo conviveu durante uma semana e pôde se apresentar para onze tribos indígenas locais. Bailarinos e alguns jornalistas saíram de Brasília com destino ao Posto Leonardo Villas Boas em um monomotor da Funai. Na bagagem os equipamentos para as apresentações e os instrumentos do músico Egberto Gismonti. Duas horas de viagem até o pequeno avião pousar na selva. Centenas de índios aguardavam a chegada do grupo. Esta foi a primeira visita de uma companhia de dança à região.

Décio Otero e Marika Gidali apresentaram o pas-de-deux Adagietto, do coreógrafo argentino Oscar Araiz, em terra batida e ao som das músicas de Gustav Mahler. O duo causou um certo alvoroço entre a platéia, uma vez que para os índios do Xingu homens e mulheres não podem dançar juntos. Depois a companhia dançou Bamboleô, cuja trilha sonora é uma colagem de músicas populares brasileiras. Após a apresentação o grupo conversou com os caciques. A troca cultural resultou no espetáculo Kuarup ou a Questão do Índio, inspirado na dança ritual dos indígenas, como 
também em seus hábitos. A coreografia tem como pano de fundo o extermínio cultural e a falta de respeito para com esses povos.

A companhia percorreu a América Latina e chegou a participar do Festival Internacional de Dança da Cidade de Havana. Em 1975 o grupo desembarcou em uma turnê pela Costa Leste dos Estados Unidos e México. Para fechar o ano, o Stagium dançou no Teatro Champs-Élysées em Paris.

As andanças do Stagium pelo Brasil tinham como objetivo levar a dança para todos os públicos, seja ele os índios do Xingu a população ribeirinha e aos engravatados que circulam pela Avenida Paulista em São Paulo. Desde a sua fundação, em 1972, o Balé Stagium optou por fazer uma dança diferente daquela que os seus fundadores tinham aprendido - o balé clássico. "Intuem que era preciso formatar uma maneira de fazer balé que se parecesse com o Brasil. E partem para a confecção de uma dança que pudesse ser apreciada por quem nunca tivesse visto nenhuma." (KATZ, 1994, p.16). Uma dança que atravessou o País de ponta a ponta.

Uma cunha que rasgou a mesmice. Sapatilhas percorrendo feiras, estádios, pátios de fábricas, praças, igrejas, favelas, clubes, escolas de todos os tipos - até de samba - e lugares tão díspares quanto aldeias do Rio São Francisco. Uma verdadeira cruzada nacional, que fabricou um mercado para a dança profissional no Brasil. (KATZ, 1994, p.18).

Com as apresentações dos espetáculos coreográficos, a companhia convertia leigos em público de dança. No Brasil, um país que pouco ou nada investe na educação para as artes cênicas, em especial, para a dança, o Stagium possibilitou a aproximação de diferentes públicos com as salas dos teatros. "O trabalho pioneiro de Marika Gidali e Décio Otero alfabetizou toda uma geração brasileira em dança." (KATZ, 1994, p. 71). 
O ditado diz: "Se Maomé não vai a Montanha, a Montanha vai a Maomé." O Stagium seguiu essa lógica: se os brasileiros não têm condições financeiras ou mesmo o hábito de ir a um teatro assistir a um espetáculo de dança, então, a companhia vai até os brasileiros. Não importava o local, não importava as adversidades, não importava qual era o público. A grande questão dos bailarinos era dançar e se fazer entender.

A dança tinha de estar próxima do cidadão, seja em sua temática, como em sua linguagem, que não abdicou dos códigos do balé clássico, porém, deixa de lado as narrativas e os libretos.

Mais que dançar, a proposta consistia em discutir temas presentes no cotidiano, mais especificamente, questões políticas e éticas dos anos 70 .

Num País silenciado pela censura e pelo medo, o Stagium se apresentou, nos anos 70-80, como um porta-voz da lucidez. Fez da dança um espaço para a consciência que resistia. Justamente a dança, o tradicional sítio amolecido dos conflitos sem tensão social. De repente, saem de cena os camponeses saltitantes, de meias $3 / 4$ impecavelmente brancas e muitas fitas nos pandeiros, e adentram nordestinos de roupas rasgadas, as mães da Plaza de Mayo, uma caninha verde com matutos encurvados. Sílfides lindas e príncipes-casadoiros são trocados pelas notícias dos jornais." (KATZ, 1994, p.19).

Décio Otero passa a coreografar questões ligadas ao dia-a-dia, às questões sociais de seu tempo: a censura debatida na coreografia Dona Maria I, a Rainha Louca; massacres como em Kuarup ou a Questão do Índio ou a questão dos direitos humanos, preconceito racial ou sexual. A dança se propunha debater a realidade brasileira e ser acessível ao público. 
Foi assim que o Stagium se tornou o fotógrafo de realidades, fazendo da sua ação, nos anos 70, a voz dos que resistiam. A luta pela democracia dirigiu esse compromisso básico de Marika Gidali e Décio Otero: foram eles os inventores dessa maneira de dançar temas seqüestrados da cidadania, numa ponte entre o teatro e a rua. (KATZ, 1994, p.32).

Questões éticas de Décio Otero e Marika Gidali transformaram-se na marca coreográfica e temática do Stagium. A estética das criações da companhia nasce de sua ética. O coreógrafo e a bailarina e diretora artística tinham como meta harmonizar a dança com o seu tempo. Longe dos contos de fadas dos balés ou do mundo de sonhos dos balés românticos, os bailarinos tinham como meta fisgar os cidadãos, convidá-los a refletir sobre a situação do País em plena ditadura militar, discutir temas presentes na vida dos brasileiros. A revolução do Stagium figurou-se acima de tudo na temática coreográfica, não exatamente na linguagem escolhida, ou seja, a técnica utilizada para a criação de movimentos e coreografias partia dos códigos do balé clássico.

No meu caso, criar balés politizados só teve razão quando os explicitei da melhor forma possível. Usando para isso a linguagem da dança, antes de qualquer mensagem política torna-se necessário que ela exista por si mesma, tornando-se, nesse caso, uma expressão artística válida. (OTERO, 1999, p. 91)

Sem mudar os códigos do balé, que possui uma linguagem própria, a companhia tratava de diferentes assuntos. $\mathrm{O}$ grupo seguia a moldura de contar uma história com a dança. No caso dos balés, o enredo necessitava de um libreto para que o conto fizesse sentido. No caso do Stagium, a narrativa permanecia sem libretos. 
Resistir, em dança, na ocasião, parecia implicar domesticação curiosa da técnica do balé. O balé, importado da Europa, se encostava na banca de jornal do vilarejo, mas não perdia sua majestade. Poderia falar até de tortura, porém os passes acabariam em pontas esticadas. A técnica que nascia na corte mais elegante da Europa do século 17, em pleno reinado de Luís XIV, agora se dedicava a educar as sensibilidades plebéias do modo mais amplo, geral e irrestrito. (KATZ, 1994, p.33).

Como destacava Baudelaire, o homem moderno é aquele que tentava inventar a si mesmo, que esforçava por criar e produzir. O Stagium procura um caminho próprio na dança, busca criar uma dança que discutisse o Brasil e focada nos brasileiros, uma dança agradável aos olhos, mas acessível a todos os públicos. Neste sentido o Stagium é considerado um dos fundadores do balé moderno no País.

A técnica é uma ferramenta para traduzir idéias e compartilhá-las com a sociedade. A linguagem é o instrumento que o artista usa para dialogar com o mundo. No caso do Balé Stagium a técnica é o meio para compor e estabelecer uma ponte com o público, a sua linguagem é a dança. A companhia usa sapatilha, ensaia grand jetés e pliés em seu treinamento diário mesmo que seja ao som de uma batucada, um ritmo bem brasileiro. O elenco da companhia dominava a técnica para mostrar aos brasileiros os seus retirantes abatidos pela miséria, ou Diadorim, saída da literatura, ou mesmo os rituais de morte dos índios. O crítico Sérgio Viotti escreveria: "Sem dúvida, a contribuição mais importante que o Stagium deu à dança foi dançar o Brasil. Os tablados onde dançaram tornaram-se mais brasileiros, e nós também, assistindo ao Stagium.”.

Uma forte influência para o modo de compor foi Maurice Béjart e o seu Balé do Século 20. Suas coreografias partem de assuntos e temas 
ligados aos debates e ao pensamento da segunda metade do século passado. Há a negação de uma dança decorativa e até mesmo acrobática realizada pelo balé clássico e sugere a expressão dos sentimentos e pensamentos humanos a partir dos movimentos do corpo. Para Béjart a dança significava a união do homem com seu próximo, do indivíduo com a realidade. A dança daria forma àquilo que não é possível descrever em palavras ou em cenas teatrais. Os bailarinos deixaram as sapatilhas de ponta e o tutu de lado, passam a vestir malhas e colante.

\section{Maurice Béjart}

No dia $1^{\circ}$ de janeiro de 1927 nascia em Marselha Maurice Béjart. Filho de Gaston Berger, filósofo, professor na Faculdade de Letras de Aix, o primeiro a influenciar com suas idéias o futuro coreógrafo que viria a ser Béjart.

Para ele (Berger), o homem pensa e age não em função apenas da razão, mas de todo o seu ser, consciente ou não; daí a importância que atribui à caraterologia. Por esta linha de idéias, é sensível ao pensamento místico do Oriente, onde observa um método que permite ao homem dedicar-se completamente a parar de pensar segundo as restritivas noções de tempo e espaço, para não ser mais prisioneiro das aparências. (BOURCIER, 2006, p311

Essas característica estão presentes nas obras de Béjart, alguns balés dedicados ao pai.

Béjart dá os primeiros passos na dança com uma ex-bailarina do Teatro Scala de Milão, a italiana Gianocci. Atua como figurante na Ópera de Marselha, vai para Paris dar seqüências aos estudos estritamente acadêmicos. Dança com Roland Petit e depois na Suécia com Birgit 
Cullberg. Mas apenas em 1953 que o bailarino consegue montar sua primeira companhia, o Ballet de l' Etoile.

Com a descoberta da música concreta de Pierre Schaeffer, Béjart rompe com o balé de repertório. Coreografa seu primeiro trabalho: Sinfonia para um Homem Só, no qual discute questões como o homem diante das transgressões do mundo, a situação das mulheres e o maniqueísmo. Neste espetáculo, cordas caem das abóbadas do teatro. A linguagem técnica utilizada na dança ainda são os passos clássicos, mas a idéia central foge dos contos de fadas e do mundo de sonhos dos balés românticos.

Nas próximas coreografias Béjart tira os tutus dos bailarinos, que passam a vestir collant e malhas. Pouco compreendido na capital francesa, a companhia se apresenta pelo interior do país e também em Bruxelas, onde terá uma recepção muito mais calorosa.

Decide em 1957 remontar A Sagração da Primavera, espetáculo polêmico apresentado pelas estrelas dos Balés Russos, de Serge Diaghilev, ao som da composição de Igor Stravinsky. Renova a linguagem coreográfica e abandona a lendária Rússia sugerida pelo músico, para mostrar o despertar da humanidade para a vida e para o amor. Apesar da ruptura, é preciso destacar que Béjart ainda segue uma narrativa: as cenas detalham a descoberta do movimento e a conquista do mundo. Além do sucesso, Sagração marca o início do Balé do Século 20, que permaneceu até 1987.

Suas coreografias partem de assuntos e tema ligados aos debates e ao pensamento da segunda metade do século passado. 
Vale destacar que Béjart se insere em uma dança moderna, no sentido que William Everdell coloca em Os Primeiros Modernos: "Os modernistas começaram justamente por rejeitar tal materialismo heróico e, com ele, o positivismo, o determinismo científico, a idéia de progresso e a fé moral.” (EVERDELL, 2000, p.21).

No início do século algumas certezas foram colocas em xeque como as artes, a sociedade e a ciência. No caso da dança do século 20, coreógrafos negaram uma dança decorativa e até mesmo acrobática realizada pelo balé clássico e sugere a expressão dos sentimentos e pensamentos humanos a partir dos movimentos do corpo.

Para Béjart a dança significava a união do homem com seu próximo, do indivíduo com a realidade cósmica. A dança, segundo ele, daria forma àquilo que não é possível descrever palavras ou em cenas teatrais. Para Everdell essa era:

uma “dança 'moderna' por não ser 'clássica' como o balé, era 'moderna' na antiga acepção da palavra, tal qual fora aplicada a Ibsen, exprimindo provocação moral. Esse tipo de dança, porém, não era 'modernista' no sentido de ser disjuntiva e espasmódica. Pelo contrário, vangloriava-se de ser contínua e fluida. A dança em geral e a dança artística em particular demoraram muito a adotar a estética discreta em ascensão. Só quando Merce Cunningham começou a experimentar sua coreografia "aperiódica" no início dos anos 1950, a dança moderna começou a ser pensada como uma montagem de 'movimentos discrepantes justapostos em staccato.” (EVERDELL, 2000, p.416).

\section{Nacionalismo}

O Stagium seguia os passos de Maurice Béjart na criação coreográfica. Como já foi dito anteriormente, o grupo estava disposto a 
discutir a realidade brasileira por meio das técnicas do balé. A grande mudança sugerida pela companhia está na temática, que fala do Brasil, sem cair no nacionalismo como ocorria com os espetáculos apresentados pelo corpo de baile do Teatro Municipal do Rio de Janeiro, por exemplo.

Nas décadas de 50 e 60 para se fazer uma dança brasileira bastava reunir em um mesmo elenco bailarinos brasileiros e a música à temática nacional ou folclórica. Não houve uma ruptura com o balé. No lugar das sílfides, surgiam uirapurus ou iaras.

Um passado que se recompõe na história do Balé do Teatro Municipal do Rio de Janeiro. Lá, na mesma companhia onde esse modo de fazer dança se consolidou, décadas atrás, seu espectro se arraigou como assombração de todos os empreendimentos de anseios nacionalistas. (...) Num percurso só seu, se pensa uma companhia de repertório de modelo europeu. O decalque impregna todas as instâncias, até que lembra da necessidade de uma certa 'cor local' na produção. (KATZ, 1994, p.53).

A companhia do Rio seguia o formato consagrado dos grandes teatros europeus e casas de ópera do século 19. Esse formato abriga roteiros de clássicos como Giselle ou aqueles com um verniz nacional.

Essa idéia de companhia surgirá anos depois, com a criação do Balé do 4. ${ }^{\circ}$ Centenário, em São Paulo. A companhia que estreou oficialmente em 1954, era presidida pela Comissão do $4 .^{\circ}$ Centenário, dirigida por outro empresário amante das artes: Francisco Matarazzo Sobrinho, o Ciccillo. O grupo nasceu com o glamour e a intenção de atingir os altos padrões das companhias internacionais e endossar os festejos do aniversário da cidade.

Apesar de sua efêmera atuação, Jânio Quadros desmontou o grupo no dia 3 de janeiro de 1956, o húngaro Aurélio Millos, contratado 
especialmente para dirigir a companhia, marcou a maneira de fazer dança no Brasil. Ele impôs aos bailarinos um regime rígido de ensaios, profissionalismo, aproximou o balé das artes plásticas com a presença de nomes consagrados na criação de figurinos e cenários, como Flávio de Carvalho, Cândido Portinari, Di Cavalcanti e Burle Marx, assim como grandes compositores do período a exemplo de Camargo Guarnieri.

No início, a companhia recebia sapatilhas importadas e tecidos italianos pagos pela Comissão do $4 .^{\circ}$ Centenário, com o fim das festividades, o grupo passaria a pertencer a cidade. Mesmo com um período de vida tão curto, a companhia concluiu seus trabalhos com um balanço de 18 coreografias em seu repertório, 700 trajes, mais de mil acessórios e 60 integrantes. Boa parte desse legado (cenários e figurinos) foi perdido ou se deteriorou nos porões do Teatro Municipal.

Alegando falta de verba, o então prefeito Jânio Quadros não quis dar continuidade ao Balé do IV Centenário que teria como sede o teatro arquitetado por Ramos de Azevedo. A elite, que criou a companhia, não estava interessada em mantê-la, o balé serviu apenas como ornamento para as festas da cidade.

O Stagium rompe com esses modelos de companhia, com este padrão pré-estabelecido para falar do Brasil para os brasileiros. Vale destacar as palavras do escritor Mário de Andrade:

Veja bem: abrasileiramento do brasileiro não quer dizer regionalismo nem mesmo nacionalismo. O Brasil pros brasileiros não é isso, significa só que o Brasil, pra ser civilizado artisticamente, entrou no concerto das nações que hoje em dia dirigem a civilização da terra, tem de concorrer pra esse concerto com a 
sua parte pessoal, com o que o singulariza e individualiza, parte essa única que poderá enriquecer e alargar a civilização", epígrafe de Mário de Andrade em A Questão da Brasilidade, no livro A Brasilidade Modernista, sua Dimensão Filosófica, de Eduardo Morais.

O Stagium discutia questões nacionais. O entendimento de nação que os criadores do balé tinham se aproximava de Benedict Anderson em Nação e Consciência Nacional, que define nação como

uma comunidade política imaginada - e imaginada como implicitamente limitada e soberana. Ela é imaginada porque nem mesmo os membros das menores nações conhecerão a maioria de seus compatriotas, nem os encontrarão, nem sequer ouvirão falar deles, embora na mente de cada um esteja viva a imagem de sua comunhão. (BENEDICT, 1989, p.14).

Homi K. Bhabha, em O Local da Cultura entende:

nação ocidental como uma forma obscura e ubíqua de viver a localidade da cultura. Essa localidade está mais em torno da temporalidade do que sobre a historicidade: uma forma de vida que é mais complexa que "comunidade", mais simbólica que "sociedade", mais conotativa que "país", menos patriótica que patrie, mais retórica que a razão de Estado, mais mitológica que a ideologia, menos homogênea que a hegemonia, menos centrada que o cidadão, mais coletiva que o "sujeito", mais psíquica que a civilidade, mais híbrida na articulação de diferenças e identificações culturais do que pode ser representado em qualquer estruturação hierárquica ou binária do antagonismo social. (BHABHA, 2003, p. 199).

\section{Stagium e o Modernismo}

O Modernismo é a síntese do século 20. Marcado pela autoreferência, pela subjetividade radical, pela perspectiva múltipla e pela 
descontinuidade. Como destaca William R. Everdell em Os Primeiros Modernos sobre as origens do modernismo:

“(...) entre seus ingredientes estavam pelo menos cinco importantes idéias associadas. São elas: primeira, que está embutido em todo o sistema que almeja a verdade uma recorribilidade ou auto-referência que automaticamente mina a coerência do sistema. Segunda, que a objetividade, a possibilidade de acordo mútuo sobre a "realidade", não se aproxima mais da verdade do que seu oposto, uma subjetividade radical que chega às raias do solipsismo. Terceira, que toda verdade implica a perspectiva subjetiva da qual derivou e que nenhuma dessas perspectivas é privilegiada. Quarta, que qualquer verdade "objetiva" a ser encontrada é indutiva ao extremo, parecendo assentar-se na regularidade estatística. A subordinação do modernismo a essas quatro idéias já é razoavelmente bem-entendida, para usar a frase de um cientista, mas todas derivam da quinta e última, que até então só tem sido descrita no nível da matéria: o pressuposto da descontinuidade ontológica - dos átomos e do vácuo.” (EVERDELL, 2000, p.402)

De acordo com Everdell "o cerne do modernismo é o postulado da descontinuidade ontológica." (EVERDELL, 2000, p.413) Na arte esta idéia de partículas independentes dos átomos fica evidente nas artes visuais no momento em que passamos a ver o objeto da pintura como um conjunto de pontos independentes de cor, quando Seurat, em seu ateliê, justapôs minúsculos pontos para agirem uns sobre os outros, reproduzindo na tela a experiência na consciência. Na literatura um exemplo pode ser o fluxo de consciência presente no livro Orlando, de Virginia Woolf. A poesia abandona as transições entre as metáforas e os padrões da prosódia. No balé, um dos eventos marcantes foi o espetáculo Parade, apresentado em Paris em 1917.

A fragmentação está presente na música, na coreografia, nos elementos cênicos e o público torna-se parte do espetáculo, não apenas um observador passivo. Esse conjunto de inovações causou espanto e vaias por 
parte de alguns, que esperavam assistir a um balé romântico nos moldes convencionais, e aplausos acalorados de outros adeptos das novas idéias e rupturas sugeridas pelos movimentos de vanguardas.

Antes de entender Parade é preciso apresentar Serge Diaghilev e seus Balés Russos. Diaghilev foi, antes de tudo, um empresário, um amante da música e das artes visuais. Foi responsável pela divulgação da obra dos impressionistas franceses e dos músicos de vanguarda na Rússia. Em 1909, com bailarinos de São Petersburgo, entre eles Anna Pavlova e Nijinski, Diaghilev cria os Balés Russos. Devido à falta de recursos, a companhia, ao contrário das demais, apresenta apenas balés curtos, uma inovação bem adaptada a um grupo itinerante. A música também era um elemento fundamental dos balés, em Pássaro de Fogo revelava um músico pouco conhecido até o momento, Igor Stravinsky.

Durante a Primeira Guerra Mundial, os Balés Russos apresentaram em Paris o polêmico Parade, com roteiro de Jean Cocteau, que misturava a dança do coreógrafo Léonide Massine, com personagens circenses, cenários do cubista Pablo Picasso e música de Erik Satie. Durante a apresentação, entre aplausos e vaias de uma sociedade chocada, o poeta Guilame Apolinaire fez um inflamado discurso.

Parade fragmenta o espaço, cada elemento cênico tem o seu peso e marca a aproximação da dança com os movimentos de vanguarda. Distingue-se dos balés românticos que levavam à cena fadas e sonhos, mulheres idealizadas e amores impossíveis. Mesmo assim, Parade não rompe completamente com a linguagem do balé clássico, os bailarinos dançam nas sapatilhas de ponta e mantinham os códigos estabelecidos desde os balés de corte. A dança ainda não é auto-referente. 
Essa idéia de grande companhia influenciou a criação do Balé do IV Centenário em São Paulo, por exemplo. O Balé Stagium, no entanto, dá um passo a diante ao discutir assuntos brasileiros e ir ao encontro das platéias. A companhia estabelece um diálogo com seu público assim como faz com a música ao mixar composições clássicas ou eruditas com populares. Décio cria um elo entre a agenda nacional, questões éticas e políticas, assim como com a literatura e as artes plásticas, com suas coreografias. Foge dos temas clássicos e folclóricos, contudo, sem romper com a técnica do balé. 


\section{Capítulo 3: O Balé da Cidade de São Paulo}

Neste capítulo, procuro entender o papel do Corpo de Baile/Balé da Cidade de São Paulo nos anos 1970, na cidade de São Paulo. Vale lembrar que a companhia foi formada em 1968, com o nome de Corpo de Baile Municipal, seguindo os padrões clássicos, visando a contribuir com bailarinos para as grandes produções de ópera do Teatro Municipal.

Em 1974, sob a direção de Antonio Carlos Cardoso, o grupo abandona o balé de repertório e busca uma nova linguagem, em sintonia com seu tempo e com a sociedade. Todavia, mesmo com essa mudança no modelo de companhia europeu tradicional, o Corpo de Baile/Balé da Cidade de São Paulo entra na dança moderna sem romper completamente com a técnica do clássico, segue também padrões importados como o do Balé do Século 20, de Maurice Béjart e também os Balés Russos, Diaghilev. Usa a linguagem do balé para tratar de assuntos de seu tempo, deixa de lado o folclore e as fadas para tratar de questões ligadas ao cotidiano ou às emoções.

No que diz respeito à temática coreográfica, a companhia também permaneceu distante do debate político engajado, como queria a patrulha ideológica da época. Apesar de não entrar profundamente em questões ideológicas, a companhia dançava assuntos ligados ao dia-a-dia do Brasil, principalmente nas coreografias assinadas por Antônio Carlos Cardoso como em Aquarela do Brasil, de 1978, que segundo o coreógrafo pretende mostrar "que a juventude atual ainda reage, cobra, reivindica" (Katz, Helena, Corpo de Baile Dança Hoje sobre um Lago, in Folha de São Paulo, 28/10/1979).

\section{História}


O Balé da Cidade de São Paulo nasceu como uma companhia de dança clássica em 7 de fevereiro de 1968 pelo prefeito Faria Lima, com o nome de Corpo de Baile Municipal. Tinha como proposta acompanhar as óperas do Teatro Municipal e se apresentar com as obras do repertório clássico. Seu diretor era Johnny Franklin ${ }^{4}$,e a primeira apresentação pública da companhia foi em 11 de setembro de 1968 para acompanhar uma ópera, e em 6 de abril de 1969 a companhia fez sua primeira apresentação como Corpo de Baile com o espetáculo Les Sylphides. Mas é preciso voltar um pouco na história para entender a formação desta companhia.

O Balé da Cidade de São Paulo surge como uma companhia que segue os padrões europeus clássicos de dança. Nasce como um corpo de balé clássico para acompanhar grandes produções do Teatro Municipal de São Paulo, principalmente óperas.

A dança é entendida neste momento apenas como um adorno para a música, não havia preocupação em pesquisa de linguagem, muito menos na temática, o que fica claro no texto do crítico Acácio Vallim ${ }^{5}$ quando analisa a história da companhia.

Durante as primeiras décadas do século $\mathrm{XX}$ as temporadas líricas apresentadas no Teatro Municipal de São Paulo representavam uma forma de entretenimento

\footnotetext{
${ }^{4}$ Johnny Franklin (1931-) bailarino, coreógrafo e professor, começou a estudar com Maria Olenewa (1944), dando prosseguimento com I. Schwezov, N. Verchinina, V. Veltchek e Tatiana Leskova. Entrou para o Balé do Teatro Municipal do Rio de Janeiro em 1945, foi promovido a primeiro bailarino em 1951 dançando todo o repertório da companhia. Coreógrafo e professor do Balé da Juventude (1952-53). Criou coreografias para a televisão e para o Balé do Teatro Municipal do Rio de Janeiro. Foi diretor do Corpo de Baile do Teatro Municipal de São Paulo entre 1968 a 1973.

${ }^{5}$ Acácio Vallim foi crítico de dança do jornal O Estado de S. Paulo e é coordenador do curso de dança da Universidade Anhembi Morumbi.
} 
bastante apreciada pela população. No entanto, apenas o palco era brasileiro. Todos os componentes das óperas eram importados porque não existiam na cidade profissionais habilitados para desempenhar os diversos ofícios da cena. Diante dos custos elevados de produção, chegou-se à conclusão de que seria mais econômico manter aqui uma escola que preparasse um corpo de baile para dançar nas óperas em lugar de mandar vir da Europa um grupo de bailarinos e bailarinas. Como parte do repertório lírico apresenta na sua estrutura dramática trechos dançados, os bailarinos eram indispensáveis. (VALLIM, 2003, p. 36).

A prefeitura de São Paulo criou em 1940 a Escola Municipal de Bailado com o objetivo de atender a essa demanda. Os alunos participavam das óperas, mas os contratos eram temporários e a remuneração irrisória. No entanto, a formação rigorosa que a Escola oferecia propiciou que alguns bailarinos alçassem vôos internacionais como Marília Fr $^{6}$ anco e Marilena Ansaldi ${ }^{7}$, por exemplo. Como destaca Acácio Vallim, no que diz respeito à profissionalização dos bailarinos, o divisor de águas foi o Balé do IV Centenário.

O Balé do IV Centenário, companhia criada em 1953 para celebrar os quatrocentos anos da cidade de São Paulo, é um marco divisor na história da dança brasileira. Até essa data existiam, além da Escola Municipal de Bailado,

\footnotetext{
${ }^{6}$ Marília Franco foi primeira bailarina do Teatro Municipal de São Paulo e do Teatro Municipal do Rio de Janeiro, foi coreógrafa do Corpo de Baile do Teatro Municipal de São Paulo, diretora e professora da Escola Municipal de Bailados.

${ }^{7}$ Marilena Ansaldi (1934 -) Atriz e coreógrafa, foi a pioneira na criação de espetáculos que unem dança, teatro e recursos multimídia. Também é considerada a percussora da dança-teatro no Brasil.Foi aluna da Escola Municipal de Bailado de São Paulo até 1951.Em 1952 apresentou solos e passou a atuar como primeira bailarina. Em 1958 se afastou por divergências internas, mas ingressou no Corpo de Baile do Teatro Municipal. Em 1962 participa do Festival da Juventude em Helsinki, Finlândia, e segue viagem à Rússia, onde obtém bolsa de estudos no Balé Bolshoi. Em 1964 interpreta Zarema, um dos papéis principais da ópera A Fonte, de Baychisaray, e é cumprimentada por Nikita Krushev, que assiste ao espetáculo. Volta ao Brasil em 1965 dá início a sua experiência com dança moderna. A partir de 1968 é uma das diretoras da Sociedade Ballet de São Paulo, criando coreografias sobre A Casa de Bernarda Alba, de Federico García Lorca, e Maria Stuart, de Schiller.Em 1975 dá início a trabalhos solos e experiências com a linguagem.
} 
apenas o amadorismo das mestras de balé clássico e o experimentalismo alternativo de algumas professoras de dança moderna. Os espetáculos de dança que chegavam a São Paulo vinham, na sua maioria, do exterior e as moças que freqüentavam as aulas nas academias da cidade não tinham, certamente, a profissionalização como objetivo principal.” (VALLIM, 2003, p. 36).

O Balé do IV Centenário nasceu em 1953, inspirado nos Balés Russos de Diaghilev, a companhia que revolucionou o balé no início do século 20, e foi criado para as comemorações do aniversário de 400 anos da cidade de São Paulo. O diretor do balé, o húngaro Aurélio Milloss comandava os sessenta bailarinos da companhia. O Balé do IV Centenário foi uma experiência de profissionalismo neste estilo de dança, a dança clássica, mas durou pouco: o grupo foi dissolvido em 1955. O que sobrou foi um grupo de bailarinos bem preparados tecnicamente, que viviam o dilema de não possuírem mercado de trabalho em São Paulo. Muitos foram para o Teatro Municipal do Rio de Janeiro, onde até hoje a dança clássica prevalece na agenda de programação, e muitos outros bailarinos migraram para o exterior e outros palcos do Brasil. Os demais sobreviviam dando aulas em escolas ou academias e muitos simplesmente abandonaram a dança. Não havia mercado ou condições para sobreviver desta arte.

Com o surgimento da televisão muitos artistas foram absorvidos em musicais com a presença de bailarinos em cena. A televisão abriu algumas portas ao usar os bailarinos como adorno dos programas. Já a TV Cultura apresentava o Convite à Dança, no qual mostrava diversos estilos de dança: clássico, neoclássico, moderno e dança-teatro, em seus programas.

Enquanto se dedicavam a essa linha de shows, os bailarinos insistiram na busca de oportunidades para uma dança profissional mais próxima dos ideais do Balé do IV Centenário. Novos grupos se formaram com propostas mais modestas, 
com menos integrantes e com esquemas de produção simplificados. No entanto, foram grupos de existência efêmera, embora tenham importância histórica em virtude da seriedade de seus propósitos. É o Corpo de Baile Municipal, atual Balé da Cidade de São Paulo, criado em 1968 que vai garantir a dança profissional em São Paulo.” (VALLIM, 2003, p. 35).

O Corpo de Baile do Municipal surgiu com a finalidade de ser um corpo estável do Teatro Municipal assim como o coral e a orquestra. "O decreto de criação do Corpo de Baile permitiu a profissionalização das alunas da Escola Municipal de Bailado e garantiu, ao mesmo tempo, um espaço exclusivo para a dança na agenda do Teatro Municipal” (Vallim, Acácio, in Balé da Cidade de São Paulo, pág 36, 2003). Conforme analisa o crítico Acácio Vallim os 13 anos que separam o Balé do IV Centenário da criação do Corpo de Baile não foi um lapso, uma vez que os profissionais brilharam nas duas companhias.

Lia Marques foi diretora artística do Corpo de Baile Municipal e ampliou sua área de atuação ao coreografar Diagrama, com música de Saint-Saëns. Ady Addor, Neyde Rossi e Ismael Guiser permaneceram como grandes mestres da técnica clássica e pertencem ao quadro histórico de professores do Balé da Cidade de São Paulo. Ruth Rachou levou a técnica Graham aos bailarinos da companhia ampliando a gama de recursos expressivos dos intérpretes. São nomes da primeira linha do Balé do IV Centenário que levaram para o Corpo de Baile/Balé da Cidade de São Paulo um saber gestado na convivência com Aurélio Milloss e amadurecido através de uma multiplicidade de experiências (VALLIM, 2003, p. 36).

Johnny Franklyn assumiu a direção do Corpo de Baile da fundação, em 1968, até 1974, quando a companhia passará por uma reestruturação profunda. Nesta primeira fase ele seguiu os passos do Balé do IV Centenário, não no esplendor das produções, mas no que diz respeito a balé 
de repertório e peças clássicas. Não havia ousadia ou qualquer tipo de ruptura nas produções. Eram apresentadas coreografias do repertório clássico como Les Sylphides, Coppélia, Lago dos Cisne, Giselle ou obras coreografadas pelo próprio Johnny Franklin sem, no entanto, fugir aos padrões da dança tradicional.

O Corpo de Baile nasceu com uma vocação para a dança clássica e assim seguiu até 1974. A proposta do diretor era ser uma companhia nos moldes europeus, uma companhia para ser ornamento, para expressar uma dança agradável aos olhos, ligada a um universo de fantasias e sonhos, sem questionar a realidade ou o status-quo. Uma dança distante dos debates ou discussões políticas. O repertório era composto pelas coreografias consagradas do balé clássico, uma dança figurativa ligada ao conceito de balé do século 19. Não havia diálogo com seu tempo, tampouco o questionamento desse estilo de dança. Nesse sentido, o Corpo de Baile, neste primeiro momento de sua história, se assemelhava a produção do Teatro Municipal do Rio de Janeiro no que diz respeito a estrutura.

E o novo Corpo de Baile Municipal passava a ser um 'corpo estável' do Departamento de Teatros da então Secretaria Municipal de Educação e Cultura. Fora assim dado um primeiro passo para a autonomia de uma companhia de dança financiada diretamente pelo poder público. Todavia, do ponto de vista artístico, a companhia continuava atrelada aos procedimentos e gostos inerentes ao mundo operístico do Municipal, no qual tangia ao balé, isto é, às funções do balé nas óperas, com poucas ou cada vez menos oportunidades de criação independente. (DIAS, NAVAS, 1992, p. 111)

No Rio, os espetáculos eram marcados pelos balés românticos, ao mesmo tempo em que buscavam uma dança com um material temático "dentro da moldura 'de uma cultura brasileira"” (Pereira, Roberto, in $A$ 
Formação do Balé Brasileiro, pág. 125, FGV, 2003). No Rio, essa idéia de cultura nacional era expressa na temática, que abordava principalmente a figura dos índios. "A exploração do elemento indígena parecia ser talvez o único recurso possível naquele momento, pois, nele, existia a possibilidade de aliar o mito do original com a possibilidade de uma dança 'nacional', dois fatores tão caros à estética romântica" (Pereira, Roberto, in $A$ Formação do Balé Brasileiro, pág. 126, FGV, 2003).

Nas palavras de Roberto Pereira (Pereira, Roberto, in A Formação do Balé Brasileiro pág. 126, FGV, 2003): "o balé brasileiro parece que necessitou revestir-se de balé romântico para escrever sua história. Só assim poderia garantir sua tradição, sua continuidade e seus desdobramentos”.

Os balés seguiam os parâmetros românticos e europeus:

"uma escola, um corpo de baile, primeiros-bailarinos, um teatro oficial, público, crítica jornalística, além de compositores brasileiros que começaram a compor bailados, como Francisco Mignone e Heitor Villa-Lobos, e uma orquestra eficiente para acompanhar as temporadas. A dança nacional, como um de seus importantes elementos constitutivos, também deveria aparecer, mesmo que o corpo e a cultura fossem diferentes, mas a técnica quase a mesma" (PEREIRA, 2003, p. 127).

O balé do Rio se estrutura assim na primeira metade do século 20 . O Corpo de Baile do Teatro Municipal de São Paulo em 1968, eles se assemelham na estrutura: companhias de dança clássica para acompanhar os grandes espetáculos de música ou para apresentar um repertório do século 19. Em São Paulo, nenhum compositor compôs uma trilha especialmente para o Corpo de Baile do Teatro Municipal. 
Entre 1969 a 1973 foram produzidas as seguintes coreografias:

-1973- IFÉ, Marília Franco

•1973- Adage - Marília Franco

•1973- Poesia dos Deuses - Lia Marques

-1972- IL Guarany - Johnny Franklin

•1971- O Telefone - Johnny Franklin

-1971- O Maestro de Capela - Ady Addor e Johnny Franklin

-1971- O Elixir do Amor - Ady Addor e Johnny Franklin

•1971- O Cisne Negro - Johnny Franklin

-1971- Diagrama - Lia Marques

•1971- O Milagre - Johnny Franklin

-1971- A Morte do Cisne - Johnny Franklin

•1971- Dom Quixote - Petipa - Ivanov

•1970- La Valse - Johnny Franklin

•1970- The Sleeping Beauty - Johnny Franklin

•1970- Giselle - Tatiana Leskova

-1970- Carmina Burana - Johnny Franklin

•1969- Danças Indígenas - Johnny Franklin

•1969- In Memorian - Johnny Franklin

•1969- Serenata - Johnny Franklin

•1969- Noite de Valpurgis - Johnny Franklin

•1969- Divertimento - Johnny Franklin

•1969- Lago dos Cisne - Johnny Franklin

•1969 - Maracatu - Johnny Franklin

•1969 - Coppélia - Johnny Franklin

•1969 - Les Sylphides - Johnny Franklin

Como é possível observar, o Corpo de Baile tinha a preocupação de montar majoritariamente os clássicos do repertório como Les Sylphides, 
Coppélia, Lago dos Cisne, Giselle, The Sleeping Beauty, Dom Quixote, A Morte do Cisne e O Cisne Negro. Mas o Brasil dos anos 70 não queria ver fadas e princesas, não queria viver uma cultura absolutamente importada.

As questões políticas marcavam as produções artísticas e a efervescência cultural influenciava o contexto político. O Brasil vivia sob o regime militar e forte censura promovida pelo Ato Institucional de número 5, o AI-5. Peças teatrais, músicas, reportagens e livros eram censurados sistematicamente. Pessoas eram torturadas e desapareciam nos porões de órgãos do governo como o DOPS e o DOI-COD. Para alguns, a única alternativa era o exílio.

Nesse contexto, somado a bipolaridade entre esquerda (prócomunismo) ou direita (pró-Estados Unidos) gerados pela Guerra Fria, a arte não tinha como ficar fora dos debates políticos. Nesta via de mão dupla, o conservadorismo da produção do Corpo de Baile estava fora da inter-relação entre linguagem artística e vida nacional. Por essa razão José Luiz Paes Nunes, do Departamento de Cultura da Secretaria de Educação, resolveu revolucionar o Corpo de Baile:

Essa nova história do Corpo de Baile Municipal de São Paulo, ou a história desse novo Corpo de Baile, começou a ser escrita em 1973, pelas mãos de José Luiz Paes Nunes - pianista, crítico de música, animador cultural e intelectual amoroso das artes e da cultura -, em sua breve, mas notável passagem pelo Departamento de Cultura da Secretaria da Educação, numa época em que ainda não havia a Secretaria Municipal da Cultura em São Paulo. Empreendedor inquieto e espírito desassossegado, Paes Nunes achava que a cidade merecia uma companhia de dança afinada com seu tempo e, também, que correspondesse às muitas e diferentes cidades que, já na década de 1970, formavam essa única e mesma cidade chamada São Paulo. Convidada para assumir a direção do Corpo 
de Baile, a bailarina, coreógrafa e professora Marilena Ansaldi declinou do convite. Pouco afeita a funções dessa natureza, sugeriu para o posto o nome do gaúcho Antônio Carlos Cardoso, então um jovem coreógrafo e bailarino que começava sua carreira na Europa. Contatado, Cardoso aceitou o convite e mobilizou uma equipe de trabalho formada por ele, Marilena Ansaldi, pela bailarina e assistente Iracity Cardoso e pelo coreógrafo espanhol Victor Navarro. Isso tudo aconteceu entre o final de 1973 e meados de 1974, quando essas quatro destemidas criaturas começaram a trabalhar para trazer à luz uma companhia de dança contemporânea, de base clássica, aberta a diversos criadores e às múltiplas tendências da dança e do teatro de seu tempo. Como a sua cidade-sede.." (LOPES, 2003).

Antonio Carlos Cardoso aceitou o convite, deixou o Balé de Flandres, na Bélgica para assumir a direção do Corpo de Baile juntamente com Marilena Ansaldi e Iracity Cardoso. Juntos, "vão empreender a construção de um repertório que 'traduza a realidade atual, os fatos e as circunstâncias da nossa época e, em conseqüência, atinja uma camada maior e mais diversificada de público" (KATZ, 1994, p.64).

Com uma situação governamental favorável, representada na figura do crítico teatral Sábato Magaldi à testa da Secretaria Municipal de Cultura, a reforma começou em termos profundos. Aos empresários de ópera, Cardoso disse que procurasse outros bailarinos, não os do Corpo de Baile. O repertório foi totalmente modificado, deixando de lado os balés clássicos (Les Sylphides ou o $2 .^{\circ}$ Ato do Lago), quase sempre remontagens, e partindo para um programa de coreografias contemporâneas, privilegiando as criações originais. Também o modo de trabalho buscou afastar relacionamento paternalístico, em troca de uma posição independente do bailarino como indivíduo e embora as aulas continuassem sendo basicamente de técnica clássica, experimentaram-se 
outros procedimentos, sobretudo na preparação de coreografias. (DIAS, NAVAS, 1992, p.111)

Assim, a companhia buscava atingir a platéia com espetáculos mais próximos de seu tempo.

Forma-se a equipe: Iracity Cardoso (assistente), Victor Navarro (coreógrafo), Marilena Ansaldi (professora de balé), Ruth Rachou (professora de técnica moderna). As duas primeiras temporadas desovam Uma das Quatro (Victor Navarro), Sem Título (Antonio Carlos Cardoso), Medéia (Marilena Ansaldi), Paraíso (Antonio Carlos Cardoso), Danças Sacras e Profanas (Victor Navarro), Soledad (Antonio Carlos Cardoso), Cenas de Casamento (Marilena Ansaldi) e Do Romance ao Galope Nordestino (Clyde Morgan)" (KATZ, 1994, p. 64 e 65).

\section{Contexto Político}

Estes espetáculos funcionaram como uma amostra da nova proposta do Corpo de Baile sob o comando de Antonio Carlos Cardoso. Saem de cena os tutus e entra o collant da dança moderna. A temática muda, as fadas dão lugar às emoções e às questões do cotidiano.

No perfil que a companhia tomará sob o comando de Antônio Carlos Cardoso se lerá a amplitude da questão que a dança enfrenta aqui, a partir dos anos 70. Porque o engajamento com os problemas sociais representa uma aspiração legítima, mas não enfraquece o apelo trazido pelos 'conflitos íntimos'. São essas duas tendências que o Corpo de Baile do Municipal vai acomodar no seu repertório. A tarefa parece ser a de conciliar a preocupação com o bem comum, sem abandonar a idéia de felicidade privada. Satisfação pessoal sem indiferença pelo outro: individual e coletivo trazidos para a dança que se quer sintonia com seu tempo (KATZ, 1994, pág. 65). 
Uma combinação difícil, ainda mais em um período histórico marcado pela patrulha ideológica, pelo dualismo e pela repressão.

Havia uma grande discussão envolvendo os setores intelectualizados da sociedade com relação ao papel da arte. Neste momento histórico as leituras eram feitas a partir de um viés ideologicamente carregado tanto para tendências políticas de direita, como de esquerda. Alguns intelectuais, como Nelson Werneck Sodré, por exemplo, defendiam a educação das massas:

O povo, entretanto, agora como em fases anteriores, divide-se em vanguarda e massa. Massa é a parte do povo que tem pouca ou nenhuma consciência de seus próprios interesses, que não se organizou ainda para defendê-los, que não foi mobilizada ainda para tal fim. Faz parte das tarefas da vanguarda do povo, consequientemente, educar e dirigir as massas do povo (CHAUÍ, 1984, P.77).

\section{Ainda citando Marilena Chauí,}

O jogo entre alienação (popular) e racionalidade (vanguarda) ou entre a falsa consciência (do povo) e o conhecimento científico (da vanguarda) se realiza num campo de Aufklãrung, no qual o avanço das luzes no mundo, isto é, o progresso, depende da ação pedagógica de quem já as possui. (CHAUí, 1984, P.77).

Em uma sociedade marcada pela dualidade da guerra fria o artista não podia desenvolver seu trabalho pura e simplesmente sem se envolver no debate político, principalmente na década de 60. Havia toda uma implicação ideológica, como demonstra o Manifesto do CPC, redigido em 1962 por Carlos Estevam Martins' - o artista era caracterizado como alienado, aquele que 
não goza de liberdade alguma, justamente porque está alienado, não percebendo a 'falência histórica atual das estruturas sociais e econômicas'. Seu gosto 'pequeno-burguês' pela forma em detrimento do conteúdo, pela individualidade, em detrimento da coletividade, fazem com que vacile perante o público e perante a si mesmo, oscilando entre o conformismo e o inconformismo que coloca à margem da história e à espera do futuro incerto. Em segundo lugar, demonstra que a arte alienada é sórdida porque anestesia o público; é ilusória porque pretende a universalidade quando só pode ser particular, pois a minoria é a particularidade; é servil porque o artista se dobra às exigências da classe dominante. (..) Em contrapartida, o artista popular revolucionário será realmente livre - porque consciente das leis científicas e objetivas da história, contra as quais nunca se insurge -, eficaz- porque sua arte conscientiza o povo e transforma a sociedade - e verdadeiro - porque sua arte é feita sob o controle dos imperativos ideológicos do povo (CHAUÍ, 1984, p..86 e 87)

O artista vive então diante de duas opções radicais: "ou interfere no processo histórico como sujeito, ou aceita, alienadamente, ser objeto, matéria passiva ou amorfa" (CHAUÍ, 1984, p.88).

Muitos artistas seguiram por trilhas políticas, como destaca Zuenir Ventura:

O caminho que levou tantos intelectuais a essa atividade militante passa inevitavelmente por uma reflexão sobre a realidade brasileira. Para o poeta e jornalista Ferreira Gullar, que teve intensa participação na vida cultural anterior e imediatamente posterior a 1964 (foi um dos promotores do show Opinião e diretor do Teatro de Arena), a realidade 'rompia as formas, pondo à mostra o caráter político, interessado, dos valores sociais'. Por isso se passou a contestar com tanto empenho as formas e critérios culturais em vigor. 'Com radicalismo próprio das crises, uma parte da intelectualidade decidiu abandonar o campo tradicional da arte consumida por uma minoria e voltar-se para as grandes 
massas populares. E essa arte, em vista dos próprios fatores que a determinavam, tinha de ser uma arte política' (VENTURA, 1973, pág.65).

De uma maneira geral, o foco desses artistas estava na classe operária, no ideal de educar uma parcela menos favorecida da população. No entanto, o público das artes não era composto pela classe trabalhadora, principalmente nos grandes centros urbanos era formado por jovens universitários e por uma classe média próxima às experimentações artísticas.

Então, quer dizer, a experiência mostrou que o sacrifício dessas qualidades - que foi feito em função de buscar uma comunicação mais rápida, mais direta e mais ampla - não deu muito resultado porque, ao mesmo tempo que do ponto de vista literário a coisa produzida não tinha uma alta qualidade, o público ao qual a gente se dirigia (o público que agente pretendia atingir) não foi atingido (Gullar, Ferreira, in Pereira, Carlos A. M. e Hollanda, Heloísa Buarque - org. Patrulhas Ideológicas, ed. Brasiliense, São Paulo, 1980, p.62).

Ferreira Gullar refere-se às experiências focadas na classe trabalhadora, em especial ao que o CPC da UNE produziu. O público que compareceu ao show Opinião, um show politizado e crítico que ocorreu no Rio, ia às salas de cinema para assistir os filmes de Glauber Rocha, as produções teatrais de José Celso Martinez Corrêa, os festivais de música era um público crítico e informado.

Havia neste momento o crescimento da classe média, o aumento da demanda por produtos culturais, ou seja, o crescimento de uma indústria cultural. 
A existência no Brasil - pelo menos em suas grandes cidades e em algumas faixas da população - de um público relativamente amplo que já não pode deixar de consumir regularmente cultura, ou seja: ir ao cinema ou ao teatro, ler livros, manter-se informado etc. Em segundo lugar, a existência da estrutura de produção cultural (empresários teatrais, editores, produtores de cinema etc.) que mantém em funcionamento as atividades intelectuais e não poderia ser sem graves consequiências inclusive para a economia (VENTURA, 1973, pág.59).

Ao mesmo tempo em que aumentava a demanda e o consumo de produtos culturais havia a forte censura sobre as produções. Como observa Zuenir Ventura, todas as expressões artísticas encontram o mesmo obstáculo: a censura ou a autocensura. Mas de acordo com o autor:

as dificuldades desse choque têm produzido os mais variados efeitos na criação e nos criadores dos últimos tempos: desde a euforia cínica até a apatia quase quietista, passando pelo triunfalismo irresponsável ou pelo derrotismo apocalíptico. Mas em compensação nunca deixou de haver em todos os setores ensaios e tentativas - às vezes lúcidas, outras desesperadas e algumas heróicas de rejeição, resistência e não capitulação à mediocridade e às facilidades (VENTURA, 1973, pág.66).

\section{O Corpo de Baile/Balé da Cidade de São Paulo e seu tempo}

Neste contexto o Corpo de Baile/Balé da Cidade de São Paulo passa a incorporar no seu repertório espetáculos ligados ao balé moderno, ou seja, ele se afasta dos padrões do balé sem, no entanto, deixar a técnica do balé clássico de lado. Até hoje a técnica clássica continua a ser utilizada pela companhia.

Outras técnicas modernas foram incorporadas ao treino diário como a técnica de Marta Graham introduzida pela bailarina, coreógrafa e 
professora, Ruth Rachou. A técnica Graham partia do princípio da vitalidade do movimento: tension-release (contrair-relaxar) e é fundamentada na respiração. Com a dança moderna, os coreógrafos tinham liberdade para lidar com o movimento corporal, apesar de ainda usar a técnica do clássico, de maneiras distintas daquelas impostas pelo balé de repertório, o trabalhar o espaço, tempo e peso de outras formas. Com isso, a frontalidade típica do balé é substituída por movimentos tridimensionais. Cada elemento cênico passa a ter o seu peso no espetáculo.

O repertório ganha coreografias mais ousadas e experimentais e, com isso, o desconforto atingiu uma parcela da platéia mais conservadora, que não admitia a substituição dos tutus e sapatilhas de pontas por figurinos mais ousados para a época com collants e pés descalços e também por parte do elenco, dos 20 bailarinos que integravam o grupo, apenas 10 ficaram.

As mudanças que atingiram o Corpo de Baile que em 1981 passa a ser chamado de Balé da Cidade de São Paulo não param por aí. A companhia adequou o seu repertório às tendências da platéia: um público de classe média, bem informado e crítico como destaca Zuenir Ventura. No entanto, passa ao largo do debate político do momento. A busca por uma dança crítica, contestadora e que fizesse uma reflexão sobre o momento histórico não surgiu no seu palco. As coreografias falavam do Brasil, sem entrar no debate ideológico.

O Corpo de Baile do Teatro Municipal se insere no balé moderno ao negar a dança decorativa ditada pelo balé clássico. As novas coreografias valorizam a expressão dos sentimentos e pensamentos humanos a partir dos movimentos do corpo. 
O repertório do Corpo de Baile foi composto por diferentes coreógrafos, com diferentes concepções de dança e temáticas. Pela companhia, ao longo da década de 70, passaram: Antonio Carlos Cardoso, Victor Navarro, Luis Arrieta, Oscar Araiz, entre outros.

Arrieta, que chegou aqui, muito jovem, vindo de Buenos Aires para o Ballet Stagium, de onde passou para o Corpo de Baile, sempre como bailarino, começando a coreografar a partir de Camila, que estreou num workshop espécie de oficina aberta a experiências - do Corpo de Baile de 1977, passando depois, brevemente, ao repertório. Arrieta afirmou-se realmente com Presenças (1979). Coreografia superdisciplinada e de grande força, sobre as Variações sobre um tema de Paganini de Rachmaninoff, depois do que não parou de coreografar, às vezes com momentos de felicidade, como em Um Retrato (1980), para o CBM, Destino (1985), bonito painel sobre a imigração japonesa, para o Cisne Negro, ou Magnificat (1986), sobre Bach, para o BCSP, ou demonstrando certa prolixidade, como em Mar de Homens (1988) ou Les Noces (1991), para o Balé da Cidade de São Paulo, do qual também foi diretor, em 1981. (DIAS, NAVAS, 1992, p. 115).

Por essa razão, os assuntos abordados e os estilos de dança empregados nas criações coreográficas eram variados. Alguns artistas se preocupavam em tratar em suas coreografias do Brasil, como é o caso de Antonio Carlos Cardoso, contudo, sem entrar no debate ideológico do momento.

A opção foi aceita até com entusiasmo, e, depois de uma estréia meio duvidosa, terminou desembocando numa fase de ouro do Corpo de Baile, sobretudo devido à ação de jovens coreógrafos como Victor Navarro e Luís Arrieta, um espanhol, o outro argentino com amplas ligações no Brasil. Isso porque Cardoso, apesar de ter feito um ou dois trabalhos interessantes (Nosso tempo, 1976, e Aquarela do Brasil, 1979), resultou ser melhor administrador do que coreógrafo, e seu grande mérito ficou sendo o de abrir um espaço para que todos aqueles artistas - 
bailarinos e coreógrafos - pudessem exercitar seus talentos com algum desafogo. (DIAS, NAVAS, 1992, p. 114)

De uma maneira geral, a busca por uma dança crítica, contestadora e que fizesse uma reflexão sobre o momento histórico não surgiu no palco do Teatro Municipal de São Paulo. O Corpo de Baile se insere na dança moderna ao negar a dança decorativa ditada pelo balé clássico. As novas coreografias valorizam a expressão dos sentimentos e pensamentos a partir dos movimentos do corpo. No entendimento de William Everdell essa era uma 'dança 'moderna' por não ser 'clássica' como o balé, no entanto só era 'moderna' na antiga acepção da palavra ao exprimir provocação moral. Uma dança moderna, não 'modernista' no sentido de ser disjuntiva e espasmódica. Pelo contrário, vangloriava-se de ser contínua e fluida. (Everdell, William R. Os Primeiros Modernos, Record, 2000). Por essa razão, não abre mão da técnica clássica, não há uma ruptura completa com a tradição apesar do esforço para dialogar com questões de seu tempo.

Nesse sentido, o Corpo de Baile do Teatro Municipal se aproxima do Balé Stagium, ambas as companhias buscam na dança moderna novos caminhos para tratar de questões de seu tempo, sem abandonar a técnica clássica. $\mathrm{O}$ Balé Stagium seguia como modelo de companhia o Balé do Século 20, de Maurice Béjart: utilizava a técnica clássica para discutir temas ligados ao seu momento histórico.

No entanto, O Balé Stagium buscava falar do Brasil para os brasileiros, tratava em seus espetáculos de temas seqüestrados da cidadania como a questão do índio ou até mesmo polêmicos como a adaptação de Navalha na Carne, de Plínio Marcos em Quebradas de Mundaréu. O Corpo de Baile do Teatro Municipal buscava abrir espaço para a diversidade coreográfica, o que implicava em diferentes temáticas e 
diferentes concepções de movimentos, ambos se distanciaram dos temas clássicos e folclóricos. 


\section{CONCLUSÃO:}

Procurei, ao longo deste texto, apresentar dois modelos de companhia que marcaram a dança brasileira na década de 1970 companhias de dança que existem e produzem espetáculos até os dias de hoje - o Balé Stagium e o Corpo de Baile Municipal, atual Balé da Cidade de São Paulo.

Apresentei a consolidação do perfil das duas companhias no contexto da ditadura militar em que o país vivia na década de 1970, período marcado pela forte repressão política e pela censura, entre outros, à produção artística. A proposta é a de pensar que os novos meios de se expressar através da dança buscados pelas duas companhias ecoavam sintonias com os empecilhos e as dificuldades gerados pela conjuntura histórica na qual viviam.

Ambas se distanciam dos temas do balé clássico, das histórias recheadas de fadas e seres sobrenaturais, assim como do tratamento da cultura como folclore. Tanto o Balé Stagium como o Corpo de Baile do Teatro Municipal ousam, em proporções distintas, abordar novas temáticas, ao expressar idéias, sentimentos e falar do Brasil em plena ditadura militar. Assim como na temática, os grupos buscavam uma nova linguagem que estivesse de acordo com o seu tempo e em sintonia com o seu público: jovens universitários de classe média, de uma maneira geral, pessoas bem informadas. Companhias modernas, no sentido de não serem clássicas, mas que ainda mantinham vínculos com a tradição, principalmente na técnica, ao manter códigos estabelecidos desde o Balé de Corte, e no modo de pensar o palco também como um cubo a ser preenchido por corpos dançantes, cenários e música.

Os primeiros passos Balé Stagium, em 1971, vieram de uma escola de dança. A companhia se formou como uma cooperativa, sem patrocínio ou recursos do Estado. O grupo também assumiu um caráter 
mambembe ao circular pelo Brasil com a proposta de levar a dança para todos os brasileiros e ao mesmo tempo conhecer esse Brasil. O Stagium participou do projeto Barca da Cultura, se apresentando para a população que vivia às margens do Rio São Francisco e também foi a primeira companhia de dança a desembarcar no Alto Xingu.

A proposta da companhia estava em aproximar a dança de diferentes públicos. A idéia de Décio Otero, o coreógrafo residente, e de Márika Gidali, sua parceira na fundação da companhia, era de que a dança tinha de estar próxima do cidadão tanto na temática, como na linguagem, que, embora não tivesse abdicado dos códigos do balé clássico, deixou de lado os libretos. Em suma, o grupo procurava fazer uma ponte entre as ruas e o teatro.

Um dos pontos mais importantes que caracterizam o Balé Stagium neste período de 1970 a 1979 é a sua temática. A proposta consistia em discutir assuntos presentes no cotidiano, mais especificamente, questões políticas e éticas associadas à essa década. Décio Otero coreografava assuntos ligados ao cotidiano e a questões sociais, como a censura debatida na coreografia Dona Maria I, a Rainha Louca; o problema indígena em Kuarup ou a Questão do Índio; ou a questão dos direitos humanos, preconceito racial ou sexual em seus espetáculos. Décio Otero criava espetáculos para discutir assuntos seqüestrados da cidadania. (KATZ, 1994, p.32). A intenção era apresentar a dança, uma dança que discutia o Brasil e, ao mesmo tempo, convidar o público a refletir sobre ela. A mesma dupla de criadores permitiu uma continuidade na temática na sua produção, depois dessa década.

O Corpo de Baile do Teatro Municipal nasceu um pouco antes do Balé Stagium, em 1968, como uma companhia oficial, seguindo moldes e padrões consagrados dos grandes teatros europeus e casas de ópera do século 19. Uma companhia criada para fornecer bailarinos para as grandes produções de ópera e para apresentar o balé de repertório, o balé 
tradicional. A dança era entendida como um ornamento para a ópera. No período compreendido entre 1968 a 1974, a companhia apresentou coreografias consagradas como As Sílfides, Copélia, A Bela Adormecida, Gisele, Lago dos Cisnes ou produções assinadas pelo coreógrafo e diretor Johnny Franklyn, ou por Marília Franco e Ady Addor, que seguiam os padrões do balé clássico.

Em 1974, quando o Antonio Carlos Cardoso assume a direção do Corpo de Baile Municipal, algumas mudanças são promovidas. A primeira está em se distanciar do repertório clássico e apresentar ao público novos temas, mais próximos de seu tempo. Também buscou estilos diferentes de estar no palco, uma dança que não abriu mão da técnica do balé clássico, mas buscou fazê-lo de forma moderna, desenvolvendo-se como balé moderno - o que chocou uma parcela conservadora da platéia, que não queria ver em cena pés descalços ou malhas, mas, por outro lado, atingiu um outro público, mais atento aos debates de sua época.

A produção do Corpo de Baile Municipal que se inicia sob o comando de Cardoso é marcada pela variedade de estilos e temas em cena, isso porque o grupo não possui até hoje um coreógrafo residente. Antonio Carlos Cardoso que, além de diretor era também coreógrafo, procurava trazer à tona, em suas criações, assuntos ligados ao cotidiano dos brasileiros, assuntos relacionados à ditadura, como a falta de liberdade, por exemplo.

Três importantes coreógrafos que despontaram na companhia na década de 1970 foram os argentinos Luis Arrieta e Oscar Araiz e o espanhol Victor Navarro. Eles foram autores de coreografias fundamentais ma construção do perfil da companhia na época. Vale notar, porém, que lançaram um olhar estrangeiro, periférico sobre a dança brasileira. Daí a diferença e intensidade política das obras produzidas pelo Corpo de Baile Municipal/Balé da Cidade de São Paulo 
e o Balé Stagium, que contava com um único coreógrafo e brasileiro, naturalmente mais envolvido com as questões políticas nacionais.

Tanto o Balé Stagium como o Corpo de Baile Municipal/Balé da Cidade de São Paulo são expoentes das mudanças estéticas que marcaram a produção da dança na década de 1970. Ambos romperam com os temas tradicionais e com o rigor do balé clássico e passam a adotar o balé moderno em seu repertório. As duas companhias, cada uma a sua maneira, buscaram uma dança capaz de dialogar com as questões de seu tempo. Ecoando o balé moderno que Béjart transformava em referência no mundo todo, as duas companhias trariam para cá esse mesmo modo de pensar a dança, tornando-se dois expoentes do balé moderno no Brasil. 


\section{BIBLIOGRAFIA}

ANDERSON, Benedict. Nação e Consciência Nacional. Ática, 1989

AQUINO, Maria Aparecida. Censura, Imprensa, Estado Autoritário. São

Paulo, Edusc, 1999.

AU, Susan. Ballet \& Modern Dance. Thames and Hudson, Nova York, 1988.

BANES, Sally. Greenwich Village 1963. Rio de Janeiro, Rocco, 1999

BHABHA, Homi. O Local da Cultura. UFMG, 2003

BOSI, Alfredo. "Cultura Brasileira e Culturas Brasileiras" IN: Dialética da Colonização. São Paulo. Companhia das Letras, 1992

BOURCIER, Paul. História da Dança no Ocidente, Martins Fontes, 1987.

BOURDIEU, Pierre. Sociologia, São Paulo, Àtica, 1983

CAMINADA, Eliana. História da Dança, Evolução Cultural, Sprint, Rio de Janeiro, 1999.

CHAUÍ, Marilena, in Seminários, Brasiliense, São Paulo, 1984

CHINEM, Rivaldo. Imprensa Alternativa: Jornalismo Oposição e

Inovação. São Paulo, Ática, 1995.

CLARKE, Mary e Vaughan, David. The Encyclopedia of Dance \& Ballet, Pitman Publishing. Londres, 1977

COURI, Norma et. al (orgs.). Balé da Cidade de São Paulo, Formarte, São Paulo, 2003.

COUTO, Ronaldo Costa. Brasil, Uma História Indiscreta da Ditadura e da Abertura: 1964 - 1985. Rio de Janeiro, Record, 1999.

CZAJKA, Rodrigo. Redesenhando ideologias: cultura e política em tempos de golpe. UFPR, Curitiba, 2004

DEBRUN, Michel. A identidade nacional brasileira. Estudos Avançados, 4/8, USP 
DIAS, Lineu e Navas, Cássia. Dança Moderna, Secretaria Municipal de Cultura, 1992. São Paulo.

EVERDELL, William R. Os Primeiros Modernos, Record, 2000

FARO, Antonio José e Sampaio, Luiz Paulo. Dicionário de Balé e Dança. Rio de Janeiro. Jorge Zahar Editor.

FARO, Antonio José. Pequena História da Dança. Rio de Janeiro, Jorge Zahar, 2001.

FAVARETTO, Celso. Tropicália, alegoria, alegria. São Paulo, Kairós, 1979

FIORIN, José Luiz. A Linguagem e Ideologia. São Paulo, Ática, 1998.

GODARD, Hubert, Gesto e Percepção in Lições de Dança, UniverCidade

GRAHAM, Martha. Memórias do sangue. São Paulo, Siciliano, 1993

GULLAR, Ferreira, in Pereira, Carlos A. M. e Hollanda, Heloísa Buarque org. Patrulhas Ideológicas, ed. Brasiliense, São Paulo, 1980

HABERT, Nadine. A Década de 70: Apogeu e Crise da Ditadura Militar

Brasileira. São Paulo, Ática, 1994.

HOBSBAWN, Eric. A Era dos Extremos. São Paulo, Companhia das Letras, 1998.

HOLLANDA, Heloísa B. Impressões de Viagem. CPC, Vanguarda e desbunde. São Paulo, Brasiliense, 1981.

KATZ, Helena. O Brasil Descobre a Dança, a Dança Descobre o Brasil. São Paulo. Dórea Books and Art, 1994.

KUCINSKI, Bernardo. Jornalistas e Revolucionários: nos Tempos da Imprensa Alternativa. São Paulo, Scritta, 1999.

LABAN, Rudolf in Domínio do Movimento, Ullmann, Lisa, org. Summus, 1978.

LAHUERTA, Milton. Intelectuais e Resistência Democrática. Cadernos AEL/Unicamp, Campinas, 2001. 
LIMA, Luis Costa. Teoria da Cultura de Massa, Rio de Janeiro, Paz e Terra, 2000

LOPES, Rui Fontana in Balé da Cidade de São Paulo 35 Anos, http://www.baledacidade.com.br/acia.asp).

MANNING, Susan A. Ecstasy and the Demon, feminism and nationalism in the dances of Mary Wigman. Los Angeles, University of California Press, 1993

MEDINA, Cremilda de Araújo. Entrevista: o Diálogo Possível. São Paulo, Ática, 1995.

MORAIS, Eduardo. A Brasilidade Modernista, sua Dimensão Filosófica, Graal, 1978

MORAIS, Eduardo. A Brasilidade Modernista, sua Dimensão Filosófica, São Paulo, Graal, 1978

MOTA, Carlos G. "Época de revisões radicais e aberturas teóricas"/"impasses da dependência cultural" IN: A ideologia da cultura brasileira. São Paulo, Ática, 1994.

NAPOLITANO, Marcos. A Arte Engajada e seus públicos (1955-1968)

IN: Estudos Históricos, n. ${ }^{\circ}$ 28. Rio de Janeiro, 2001

NAVAS, Cássia. Dança e Mundialização. São Paulo, Hucitec, 1999.

NUNES, Benedito. Introdução à filosofia da arte. São Paulo, Ática, 1989

ORTIZ, Renato. A moderna tradição brasileira. Cultura brasileira e indústria cultural. São Paulo, Brasiliense, 1988

OTERO, Décio. Marika Gidali Singular e Plural.São Paulo, Senac 2001.

OTERO, Décio. Stagium, as Paixões da Dança.São Paulo, Hucitec, 1999.

PECAULT, Daniel. Os Intelectuais e a Política no Brasil, Ática, São Paulo, 1989

PEREIRA, Roberto, in A Formação do Balé Brasileiro, FGV, Rio de Janeiro, 2003

RENGEL, Rengel, Lenira, in Dicionário Laban, Annablume, 2003 
RIDENTI, Marcelo. Em Busca do Povo Brasileiro, Rio de Janeiro, Record, 2000.

SCHWARZ, Roberto. Cultura e Política, Paz e Terra, Rio de Janeiro, 2000.

SILVA, Alberto Ribeiro. Sinal fechado, a música popular brasileira sob censura (1937-45/1969-78). Rio de Janeiro, Obra Aberta, 1994

SIMON, The Simon \& Schuster Book of The Ballet. Simon and Schuster.NY. 1980

SOLSNOWSKI, Saul et. al (orgs.). Brasil: o trânsito da memória. São Paulo, Edusp, 1994.

SWINGEWOOD, Alan. O Mito da Cultura de Massa, São Paulo Interciência

VELLOSO, Monica Pimenta. Modernismo no Rio de Janeiro, turunas e quixotes. Rio de Janeiro, FGV, 1996

VENTURA, Z. "Vazio cultural", "A falta de ar" e "Da ilusão de poder a uma nova esperança" IN: Ventura, Z et. al. Da Resistência à Repressão. Anos 70/80. Rio de Janeiro, Aeroplano, 2000

VENTURA, Zuenir. 1968, o Ano Que Não Terminou - A Aventura de uma Geração. Rio de Janeiro, Nova Fronteira, 1988.

VIANNA, Hermano, O Mistério do Samba, Jorge Zahar, Rio de Janeiro, 2008 
Anexos 


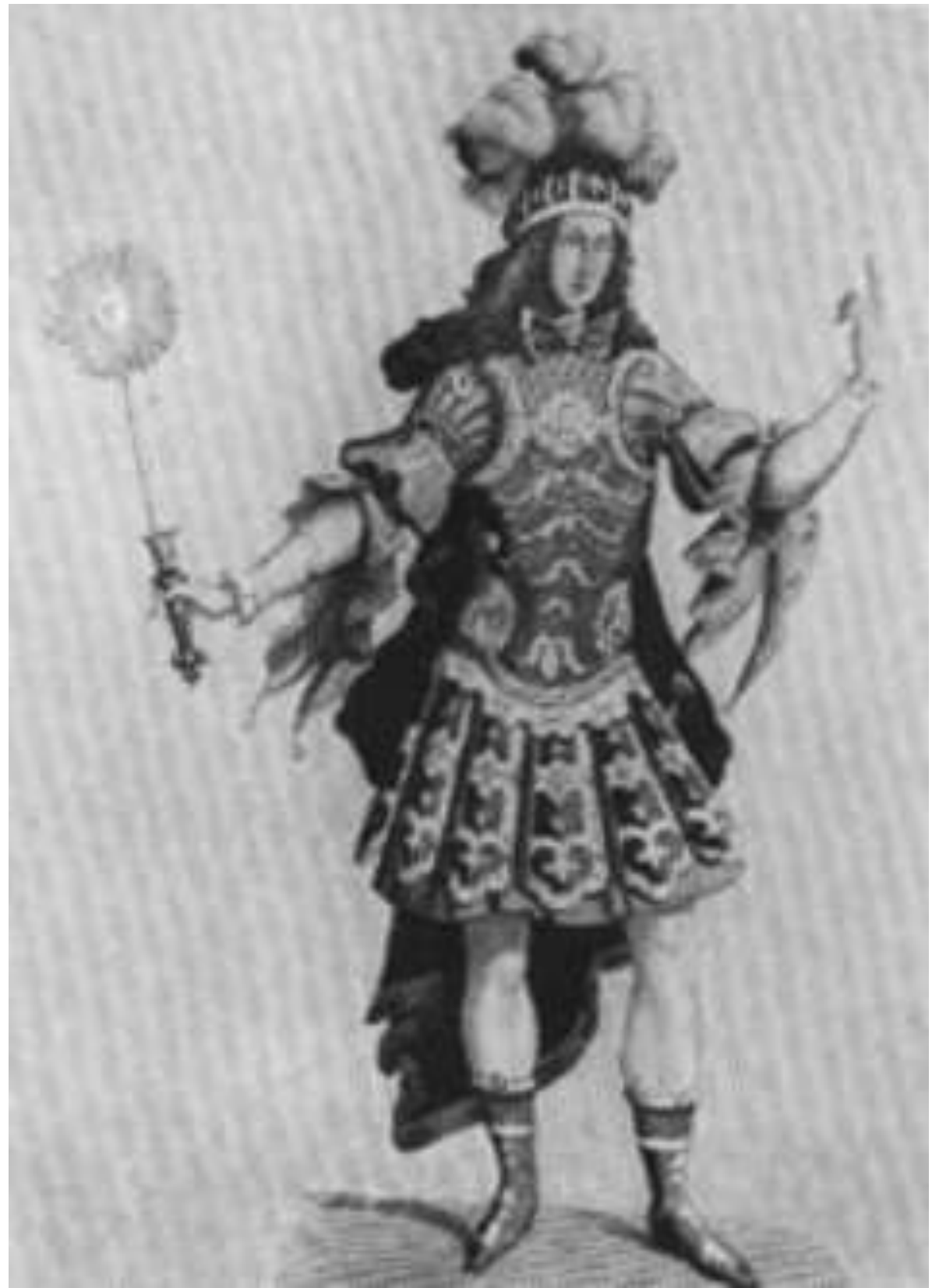

Ilustração 1

Luís XIV, o Rei-Sol 


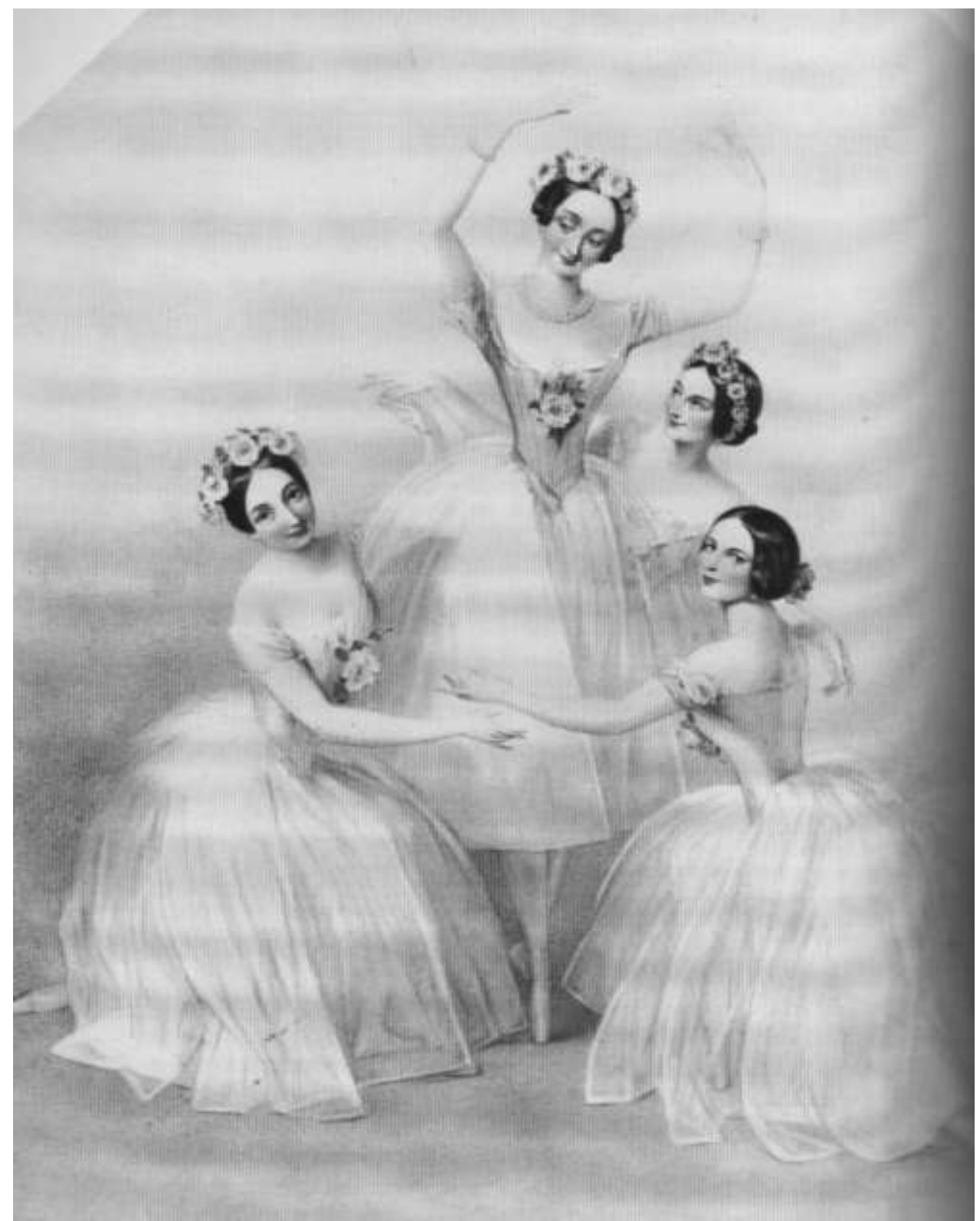

Ilustração 2

Pas de Quatre de Jules Perrot (1845) com as quatro estrelas do balé romântico: Carlotta Grise, Marie Taglioni, Lucile Grahn e Fanny Cerrtito 


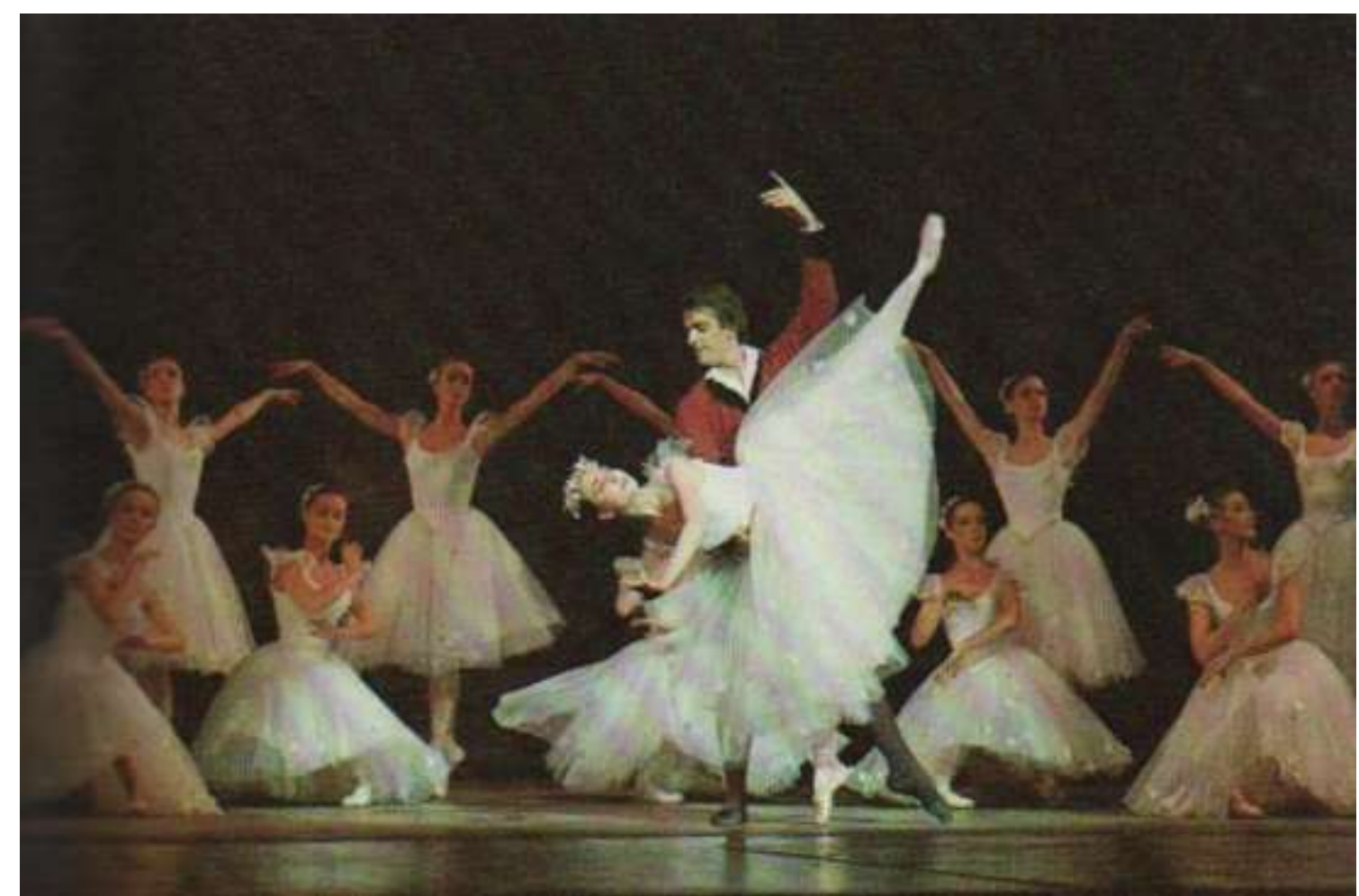

Ilustração 3 - La Sylphide (1832) a primeira grande obra do balé romântico 


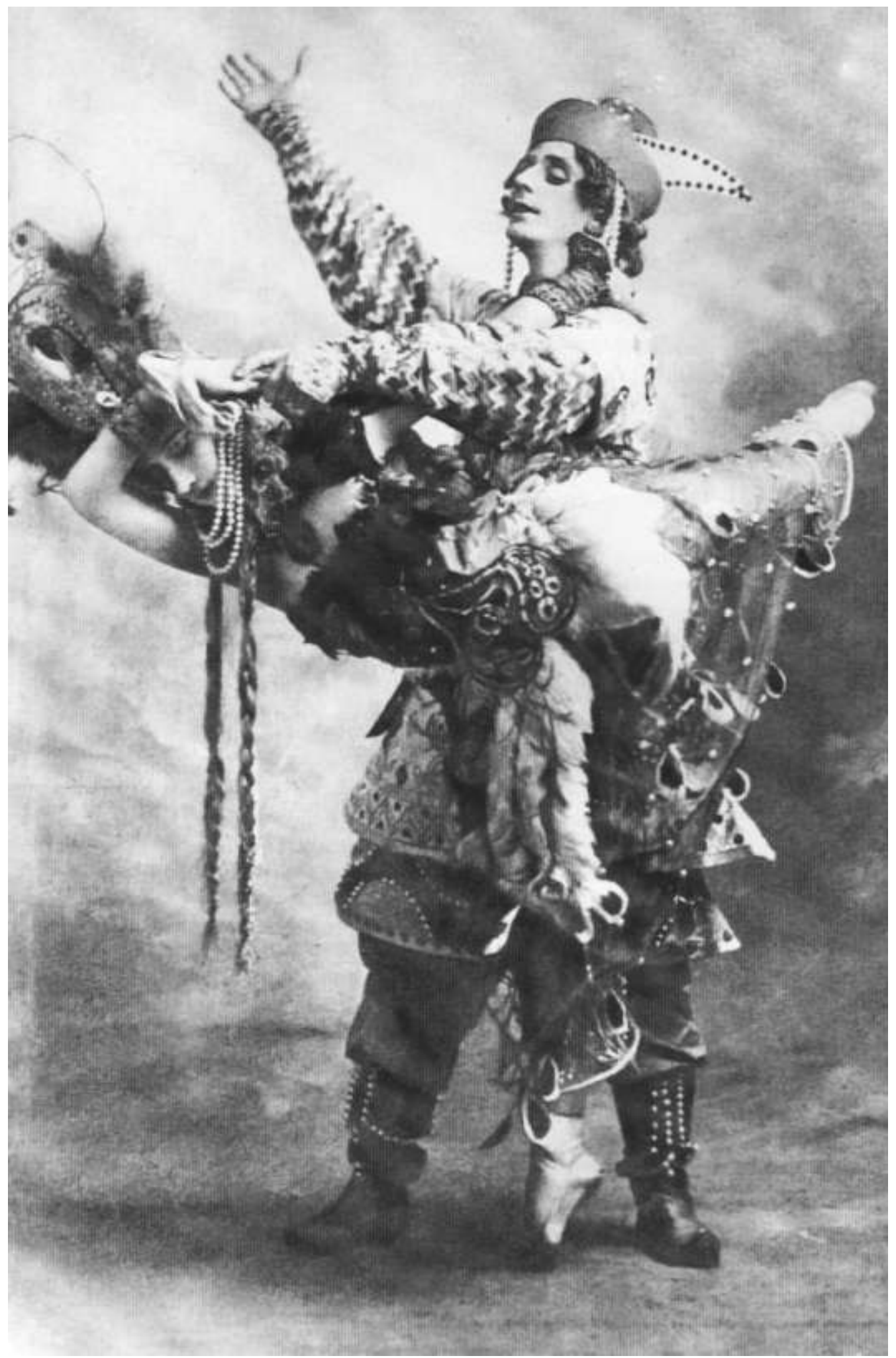

Ilustração 4 - Fokine como Príncipe Ivan captura uma criatura mágica (Karsavina) em O Pássaro de Fogo (1910) 


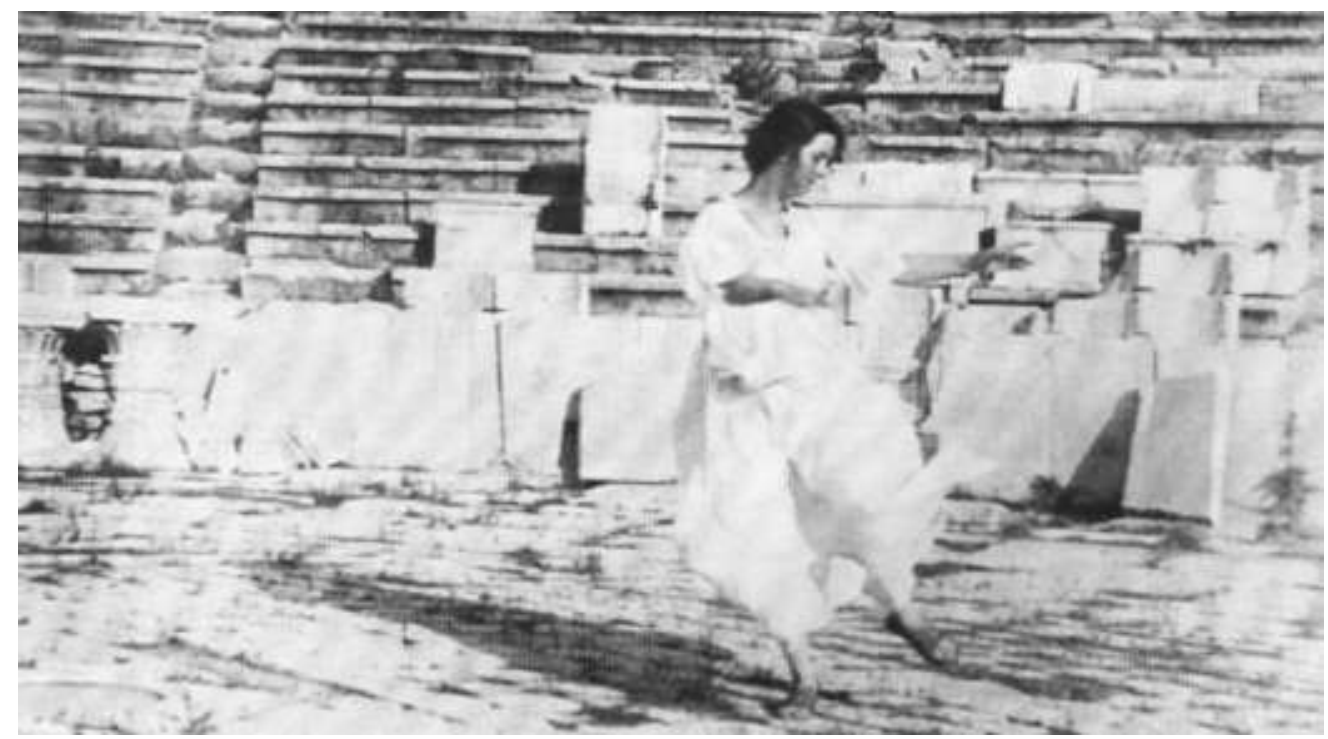

Ilustração 5 - A bailarina e coreógrafa Isadora Duncan em 1904

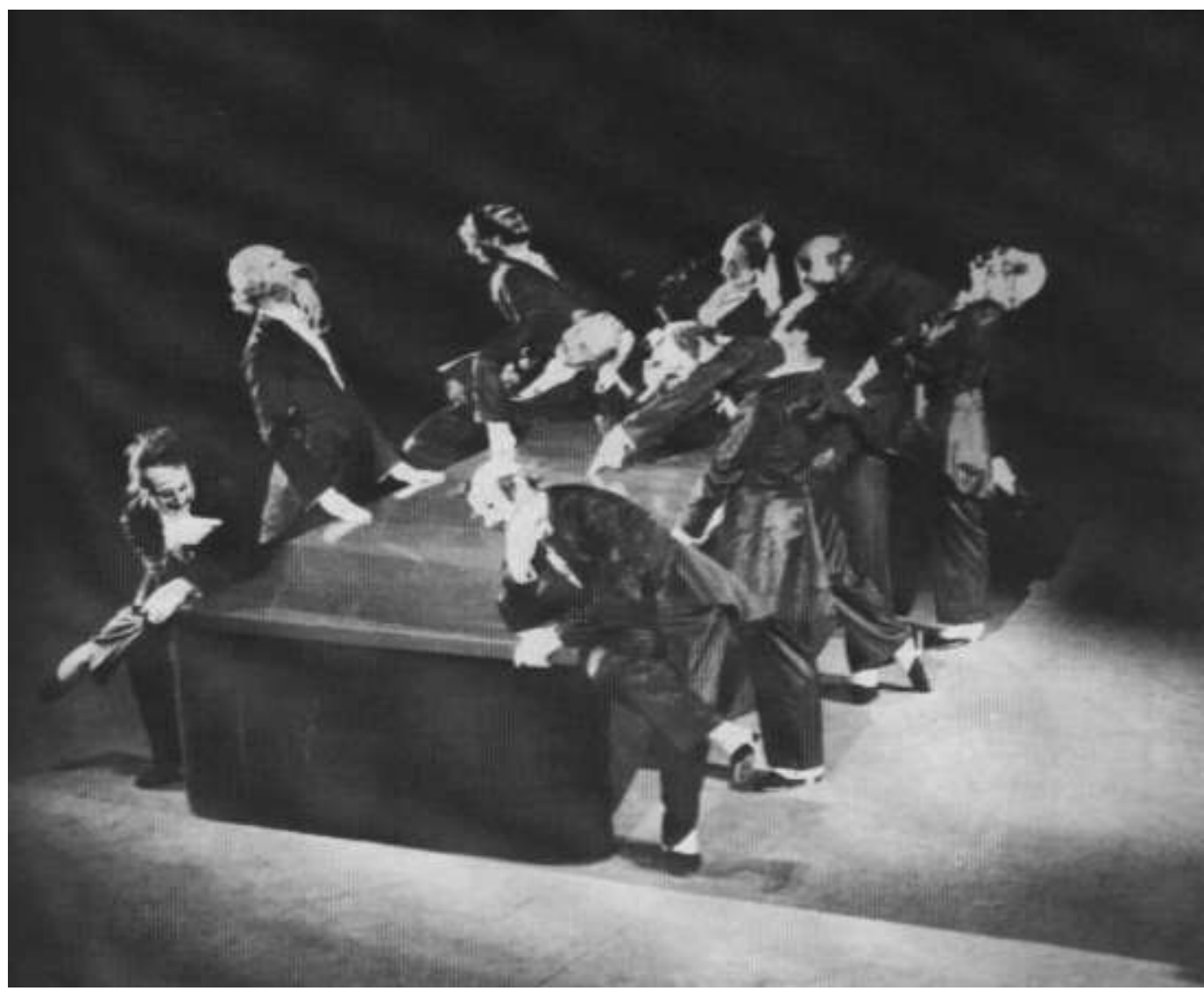

Ilustração 6 - A coreografia A Mesa Verde de Jurt Jooss 


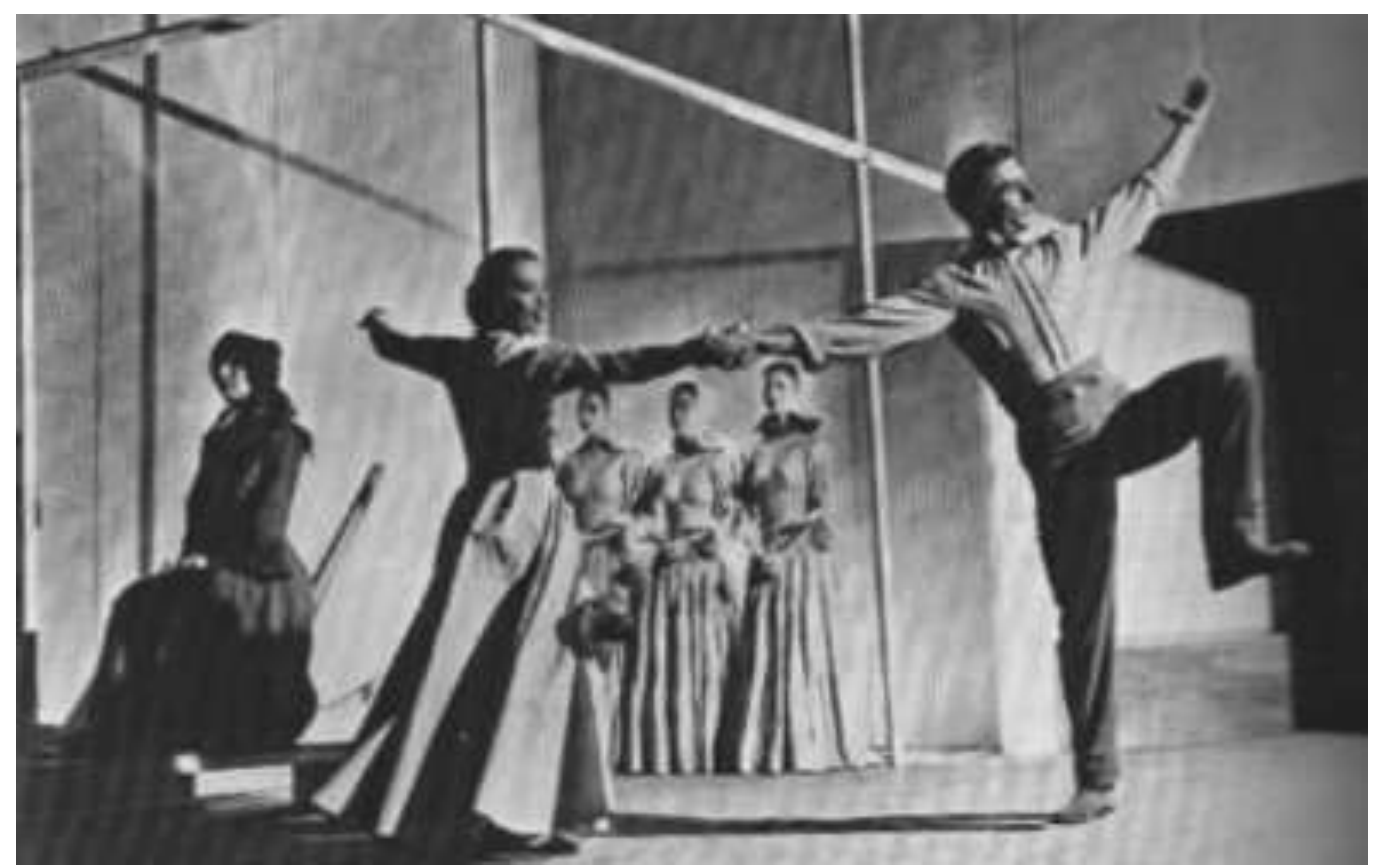

Ilustração 7 - Martha Graham em Appalachian Spring 


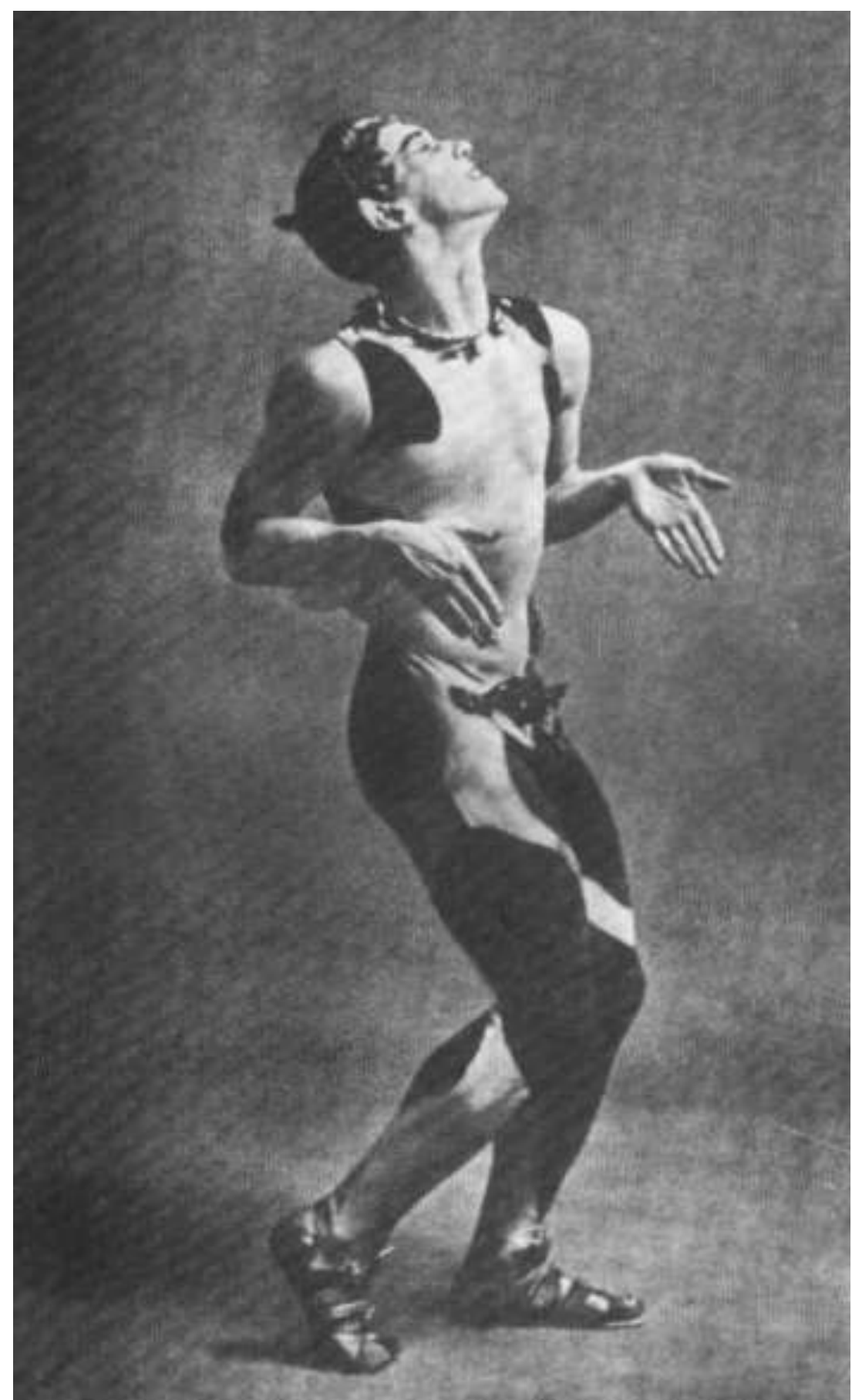

Ilustração 8 - O bailarino e coreógrafo Vaslav Nijinski em L'Aprés-midi d'un faune 


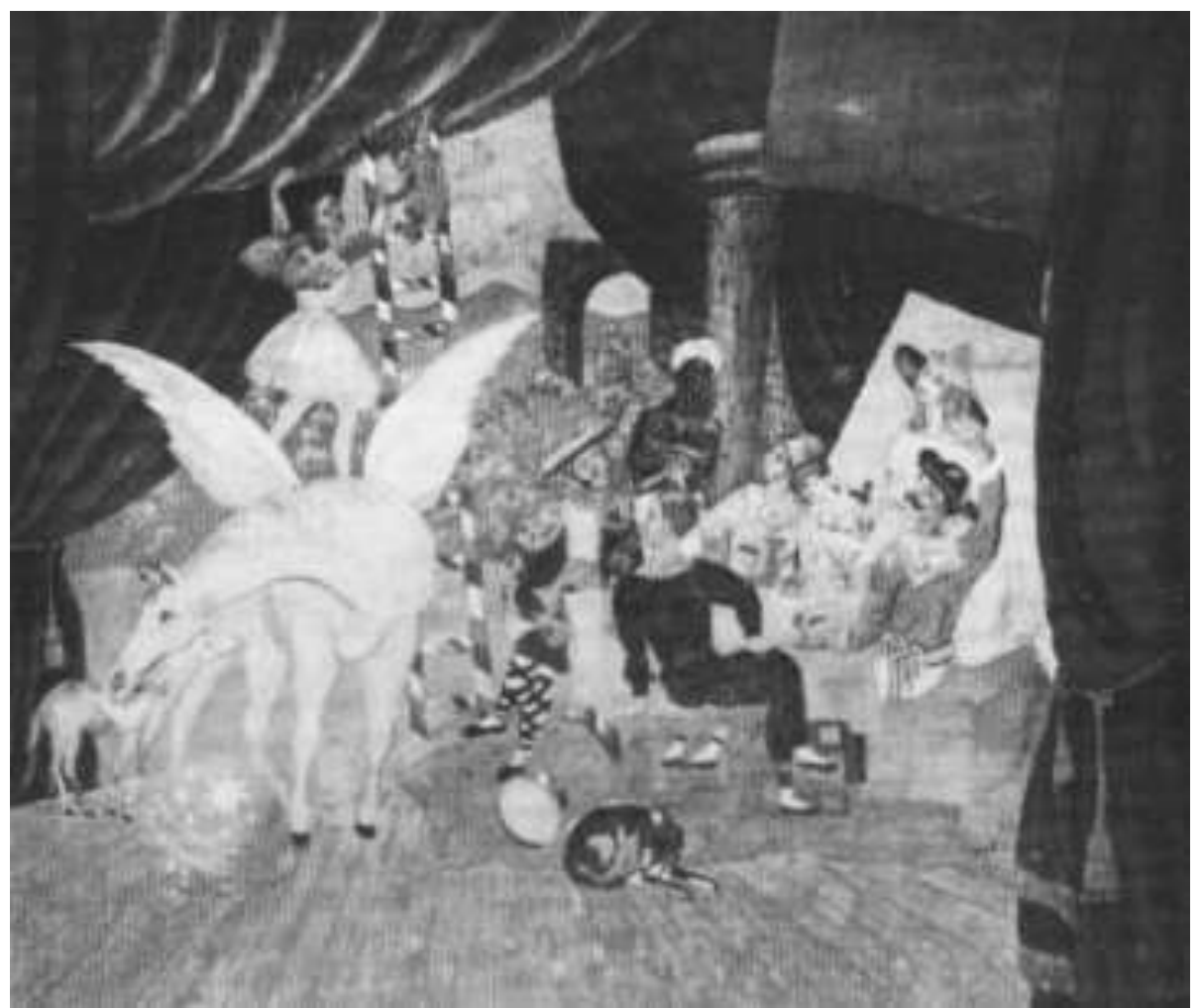

Ilustração 9 - Obra de Pablo Picasso para o balé Parade, de Massine 


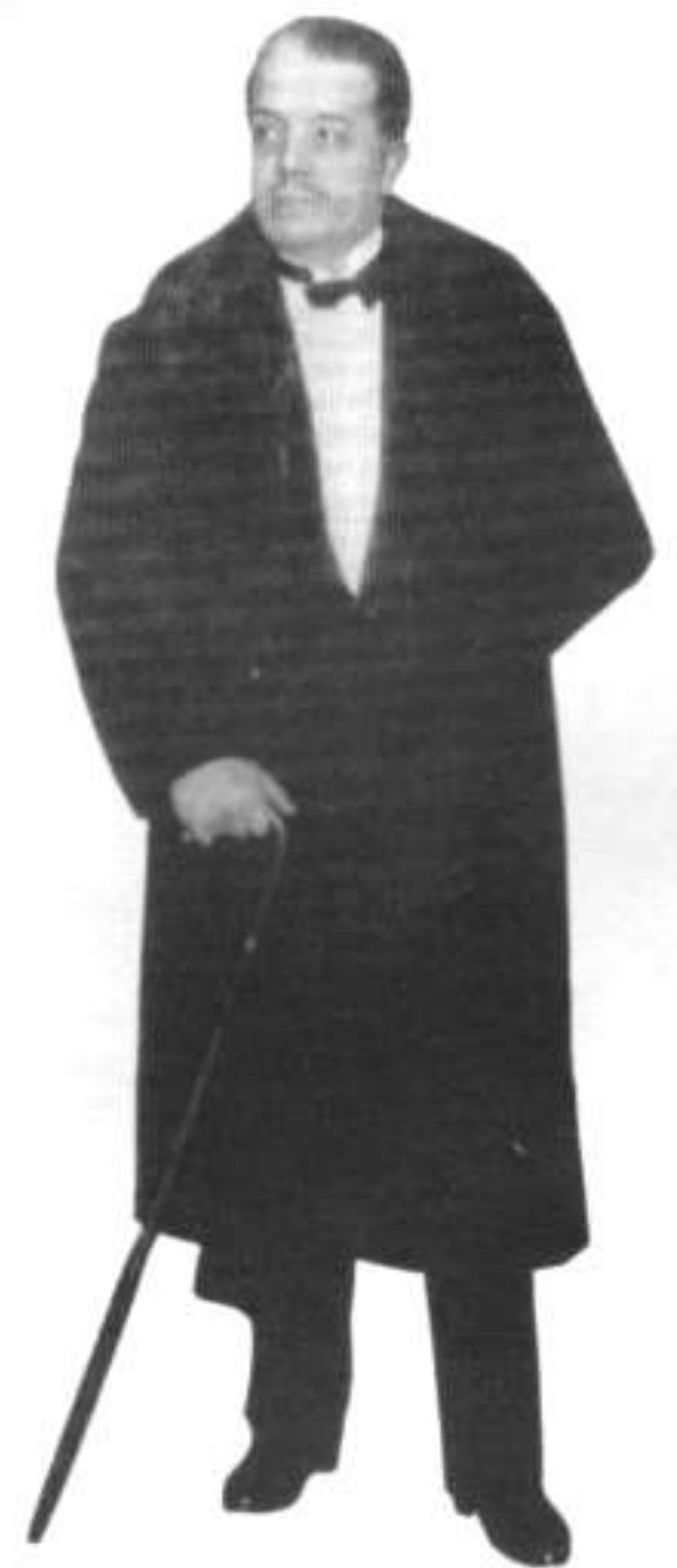

Ilustração 10 - O diretor Sergei Diaghilev em 1924 


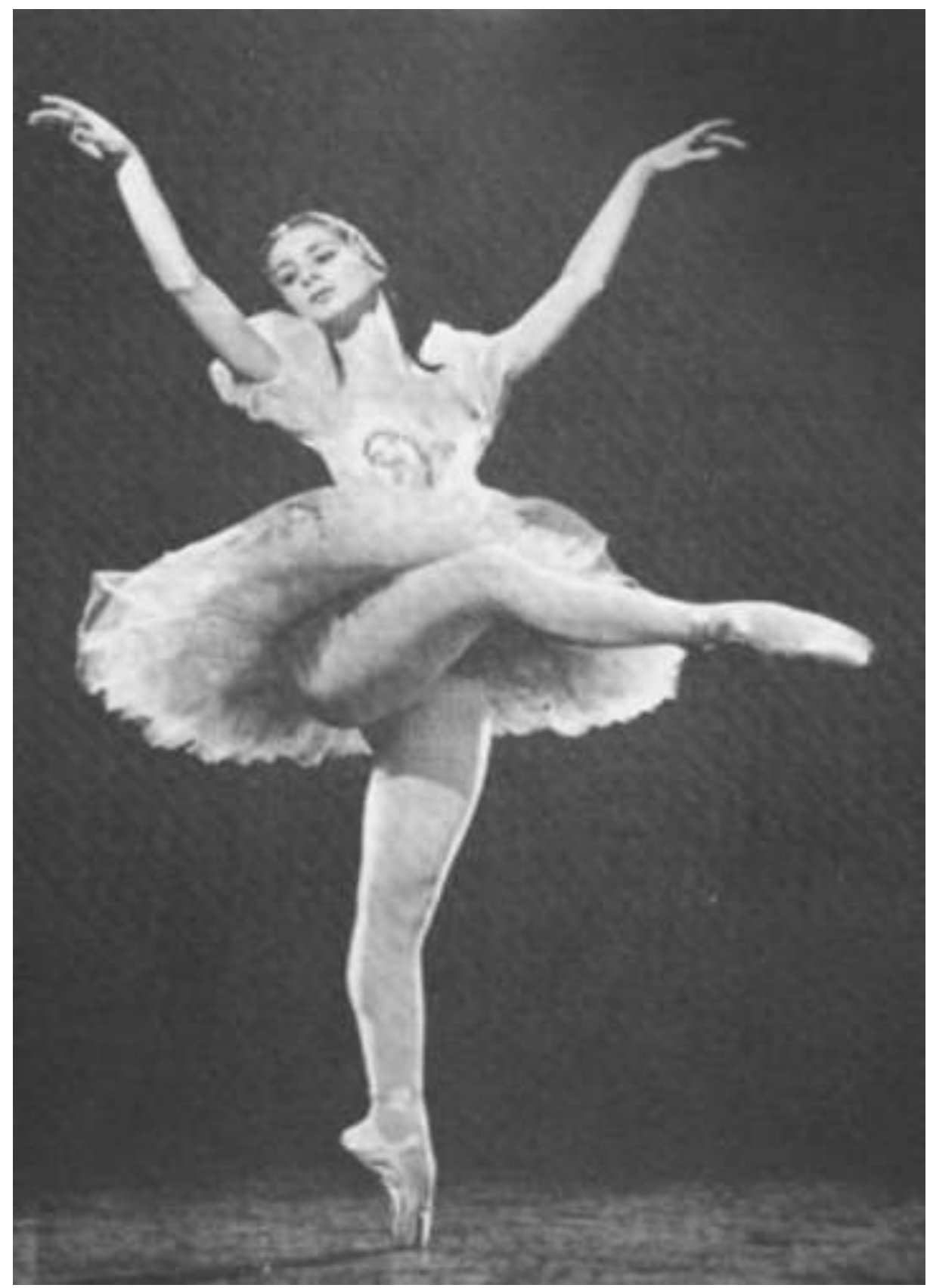

Ilustração 11 - A bailarina Ady Addor 


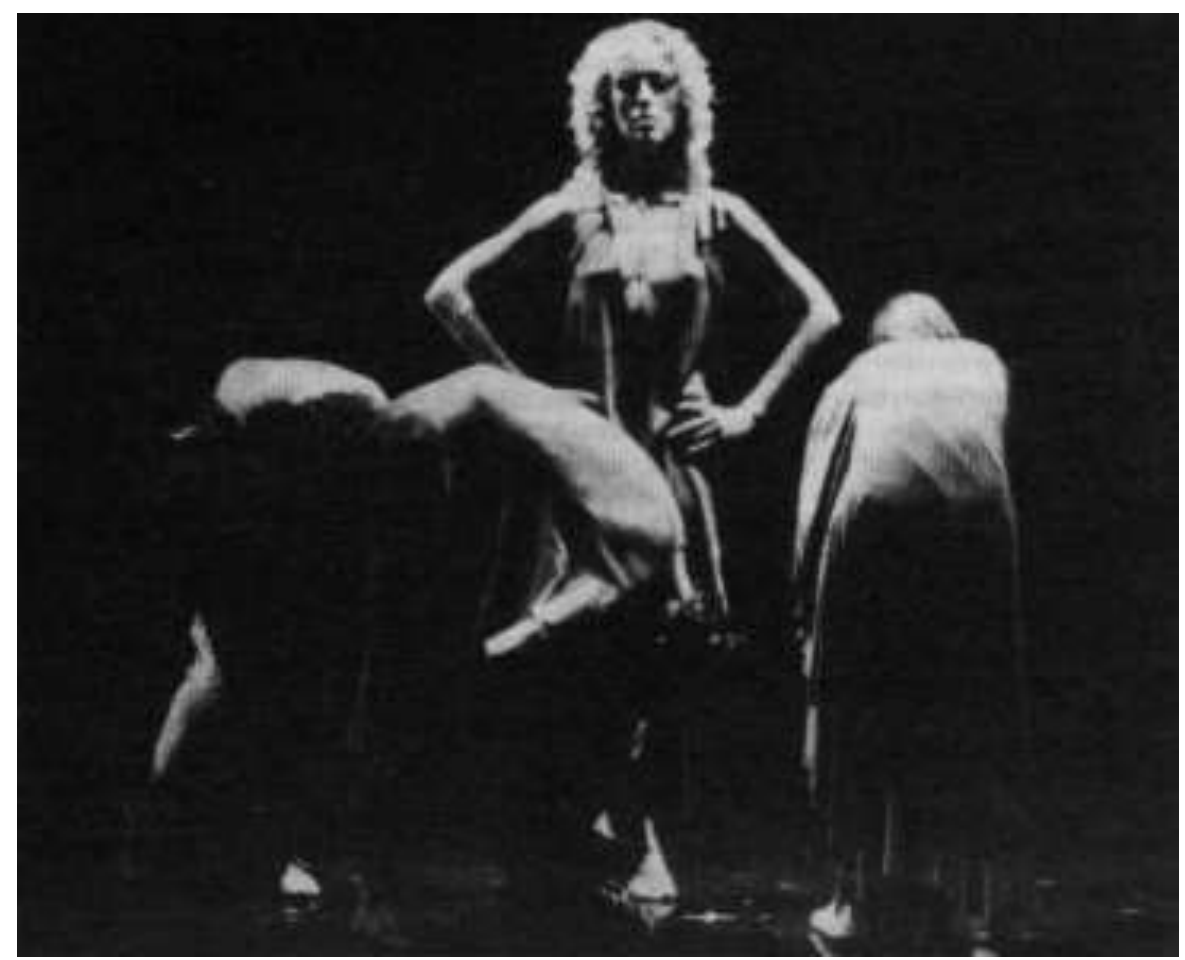

Ilustração 12 - Paixão com o Corpo de Baile do Teatro Municipal de São Paulo

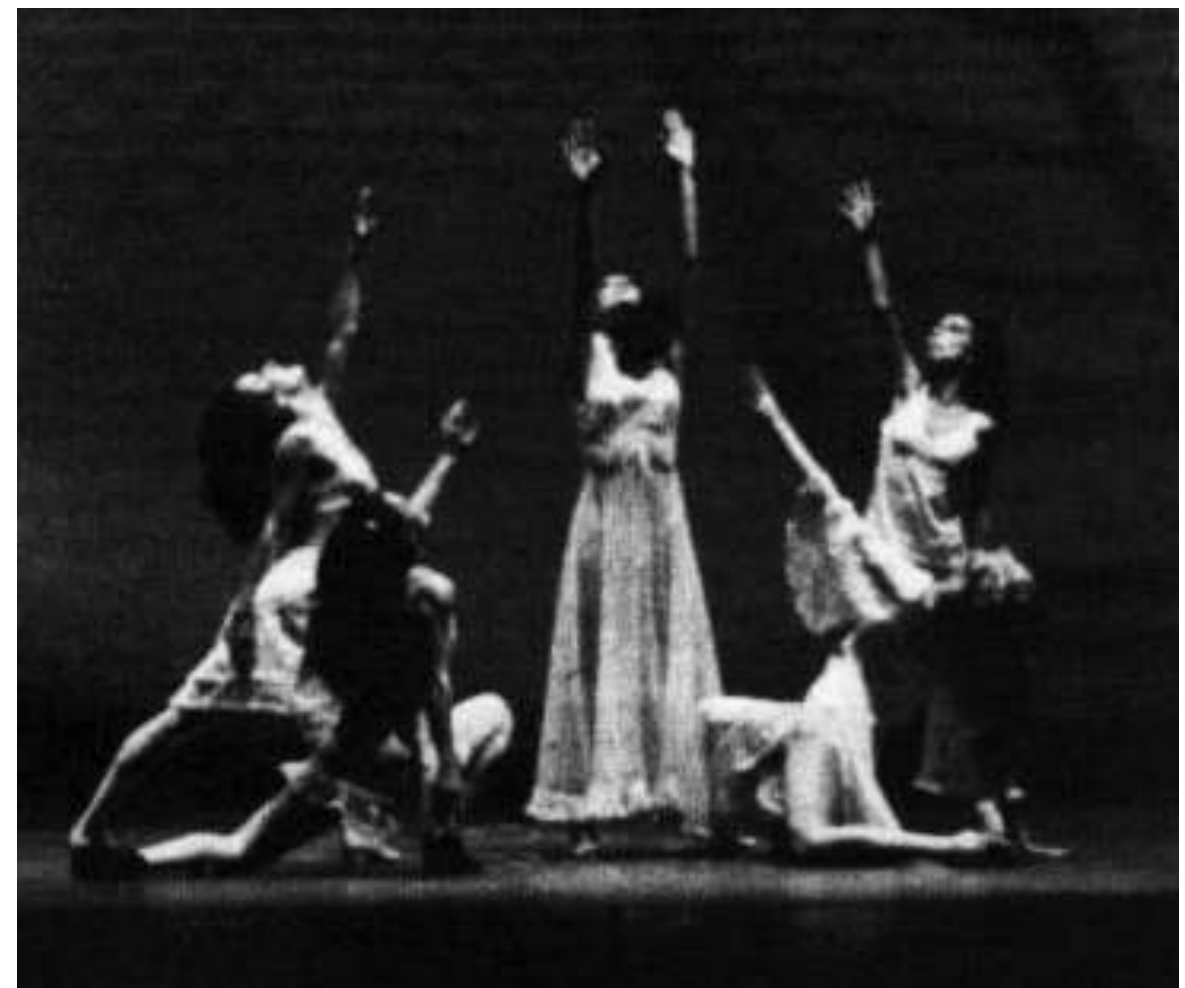

Ilustração 13 - Mulheres com o Corpo de Baile do Teatro Municipal 


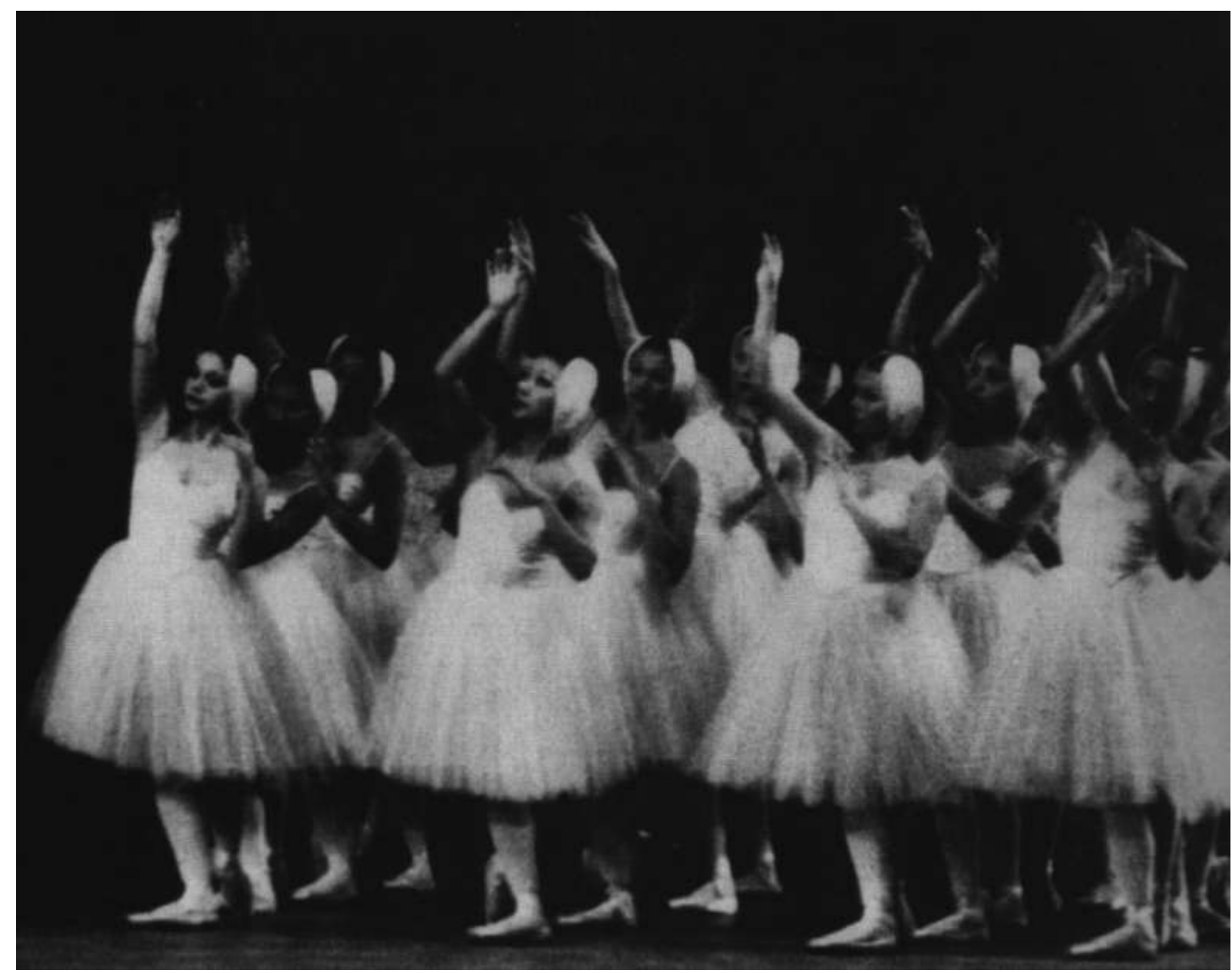

Ilustração 14 - O Lago dos Cisnes com o Corpo de Baile do Teatro Municipal 


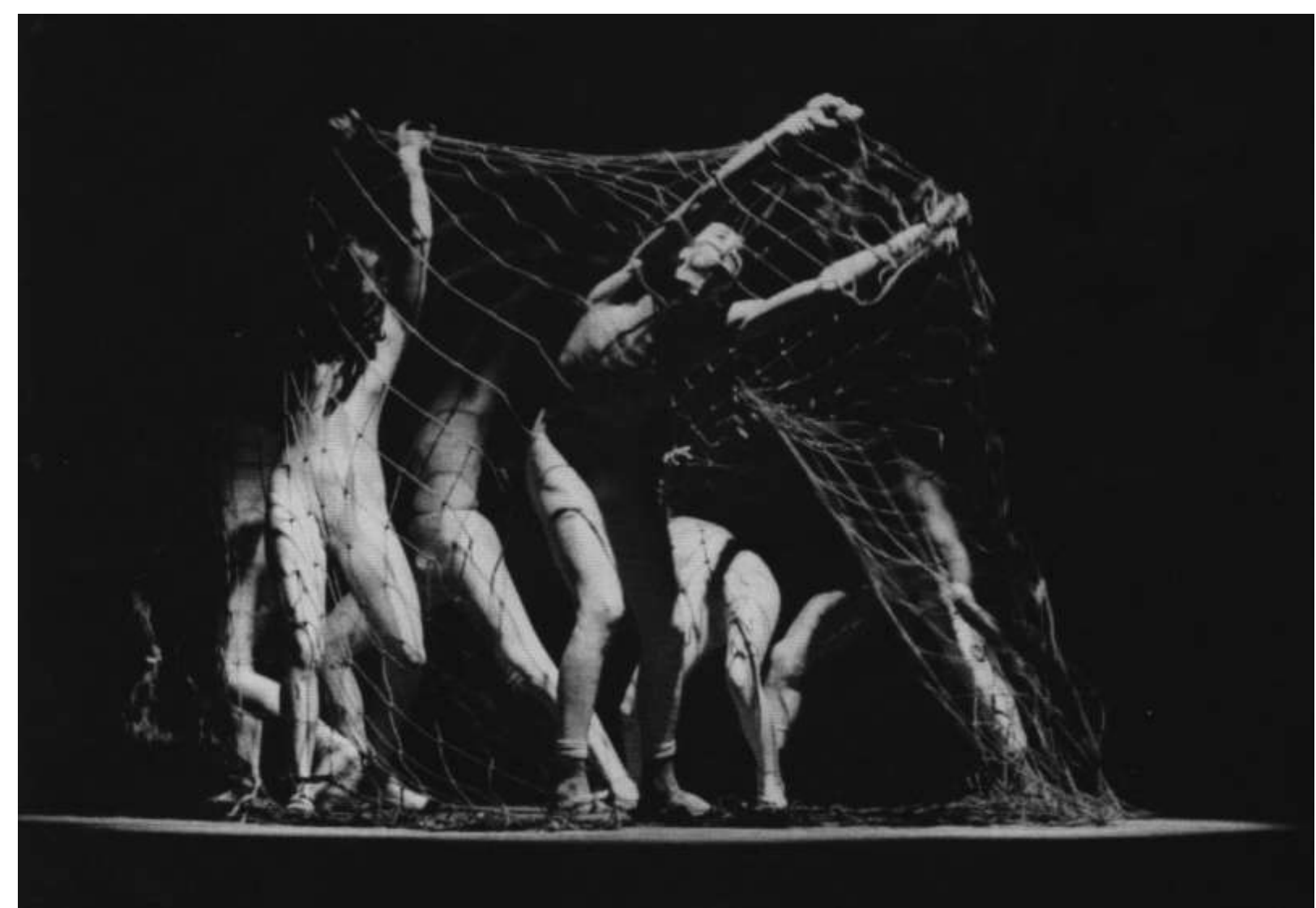

Ilustração 15 - Sem Título, com o Corpo de Baile do T. Municipal 


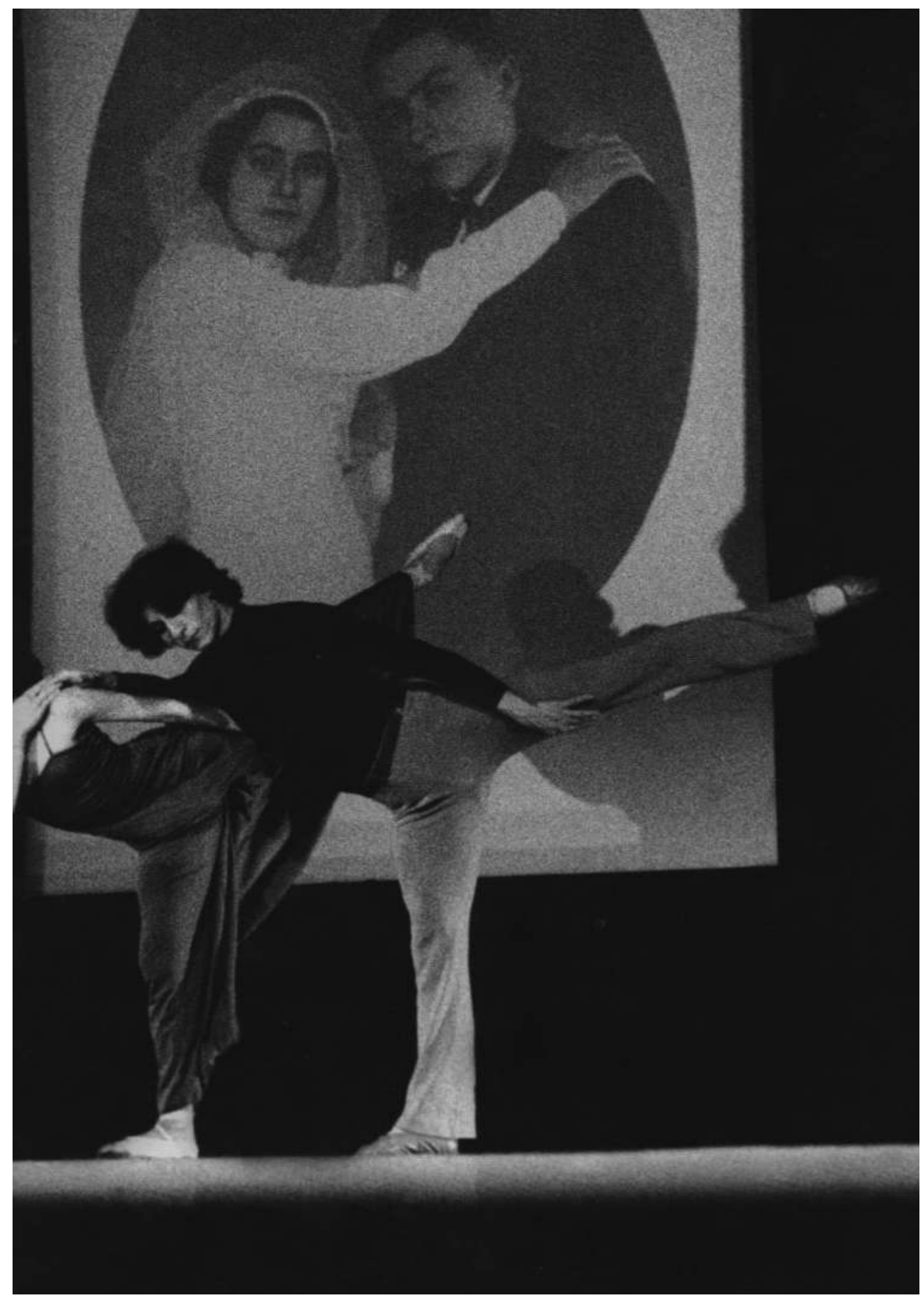

Ilustração 16- Cenas de um Casamento com o Corpo de Baile do Teatro Municipal 


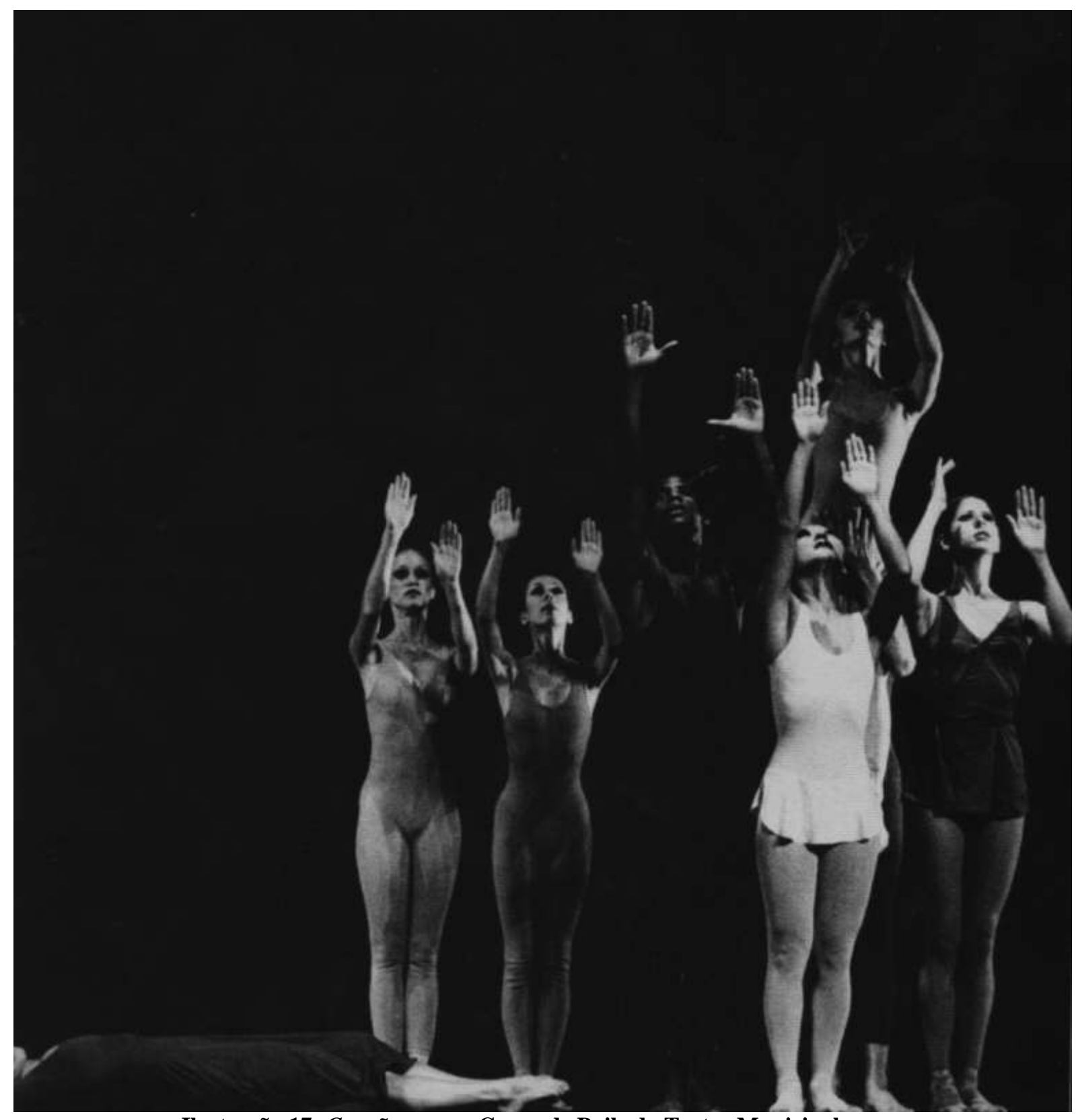

Ilustração 17- Canções com o Corpo de Baile do Teatro Municipal 


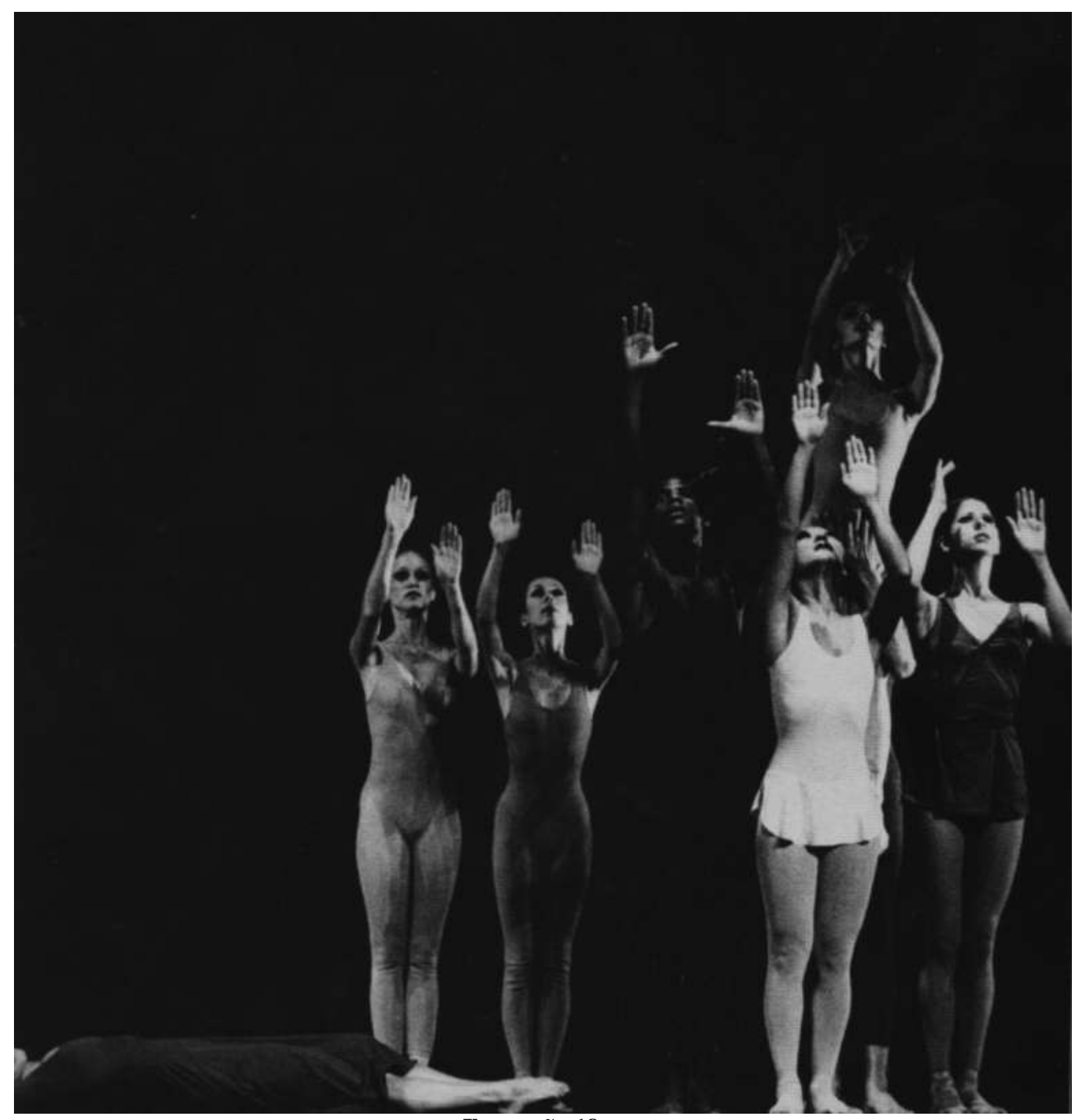

Ilustração 18 


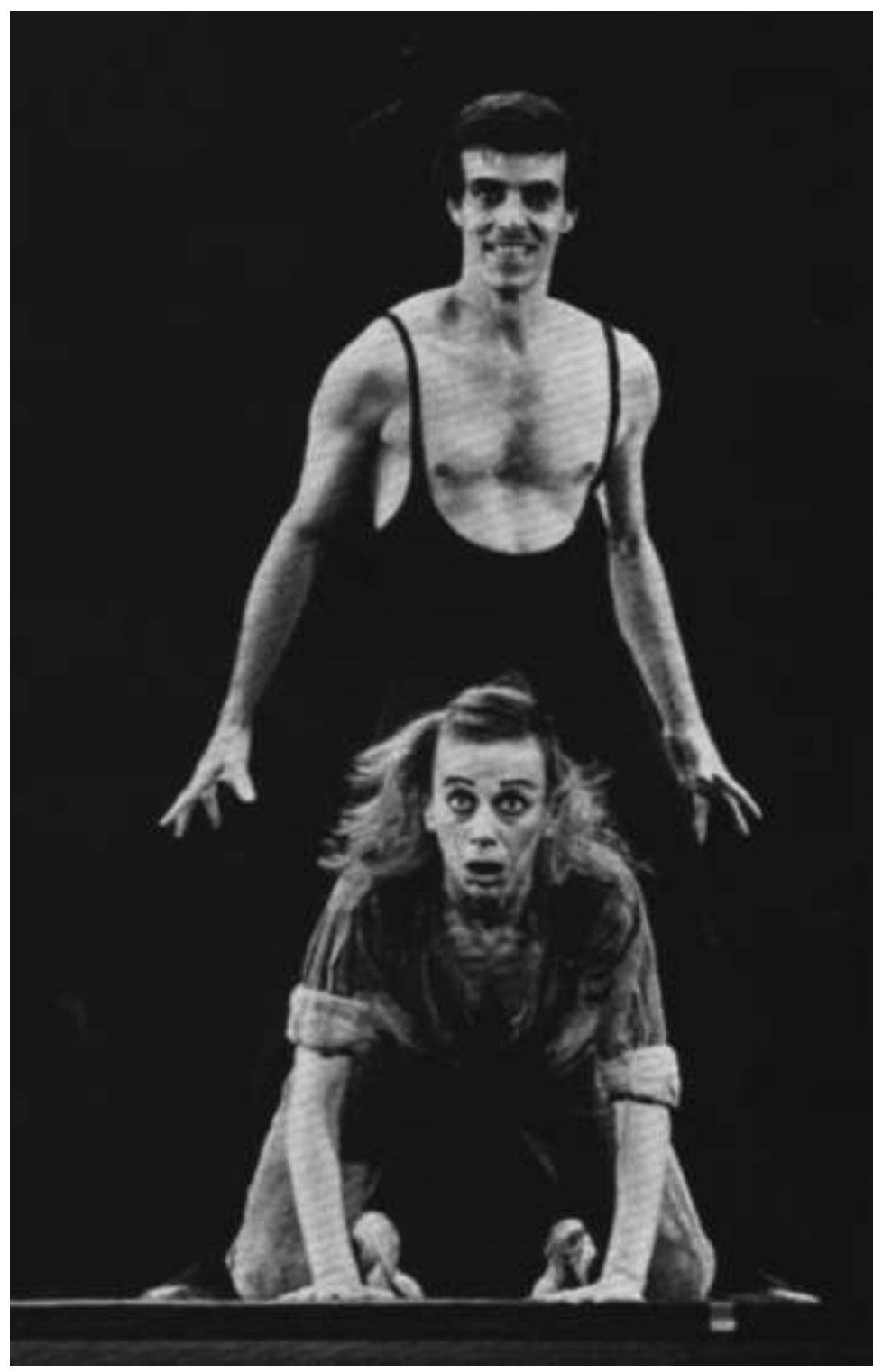

Ilustração 19- Quebradas de Mundaréu, Balé Stagium 


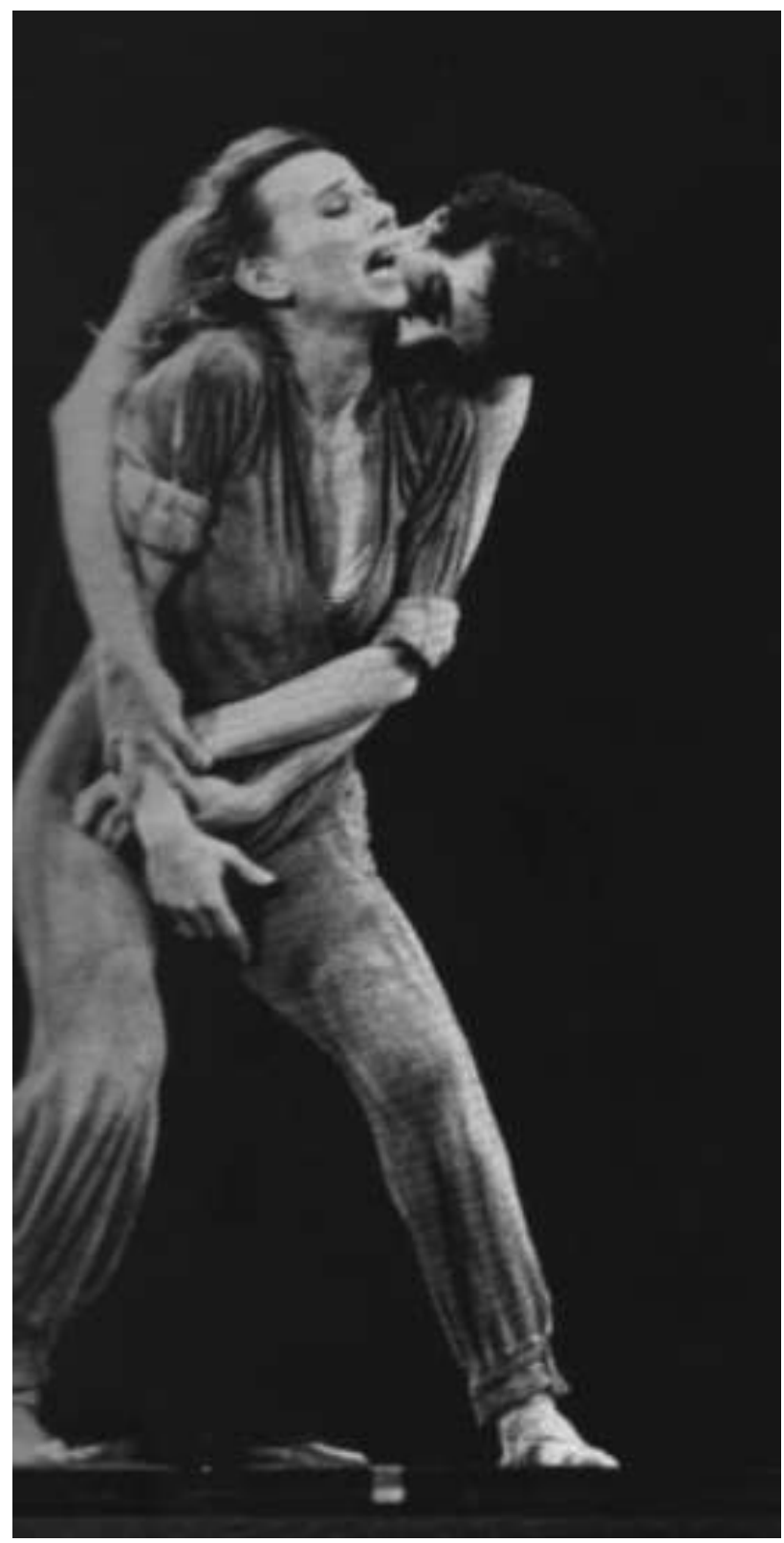

Ilustração 20-Quebradas de Mundaréu, Balé Stagium 


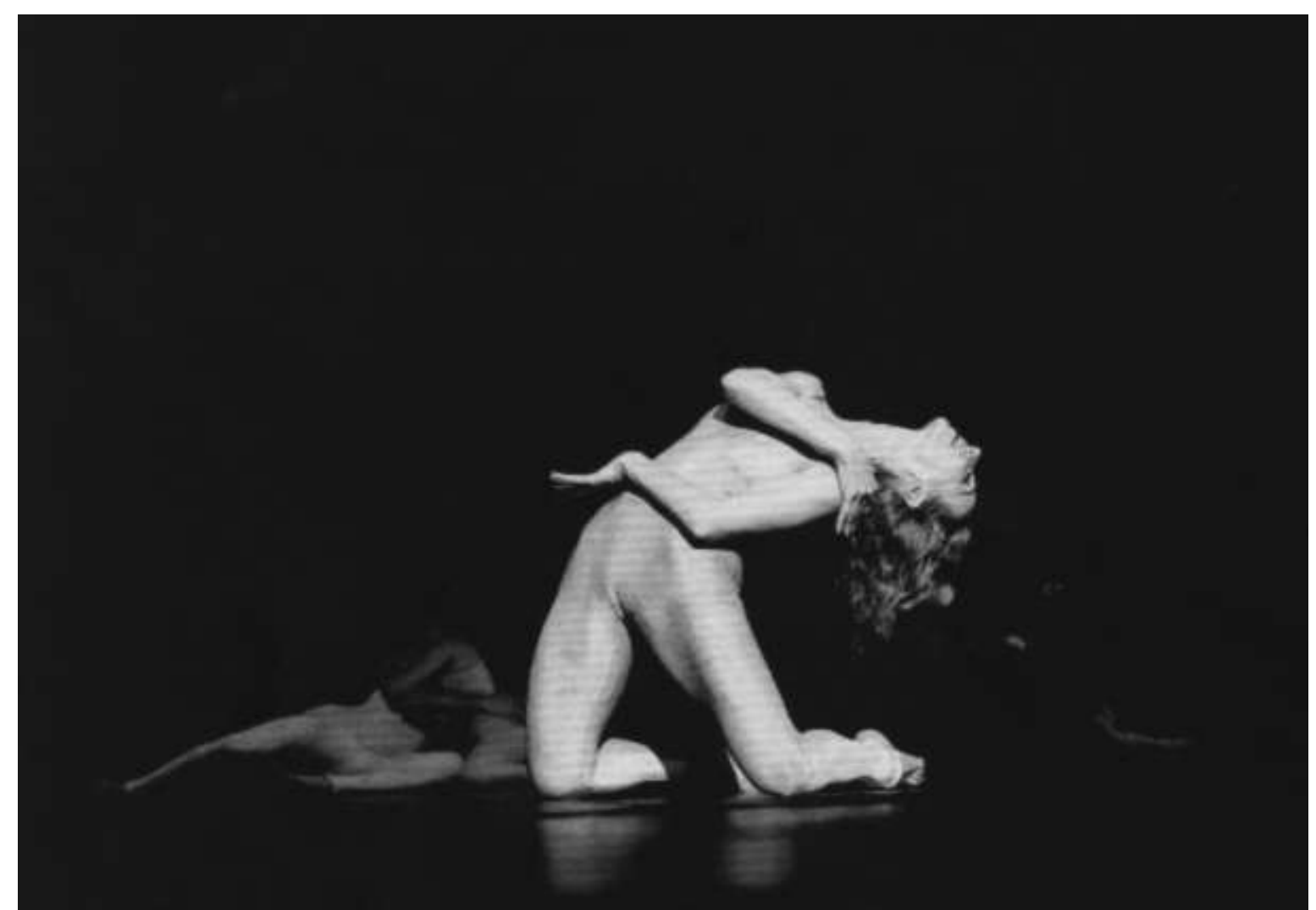

Ilustração 21 - Diadorim com o Balé Stagium 


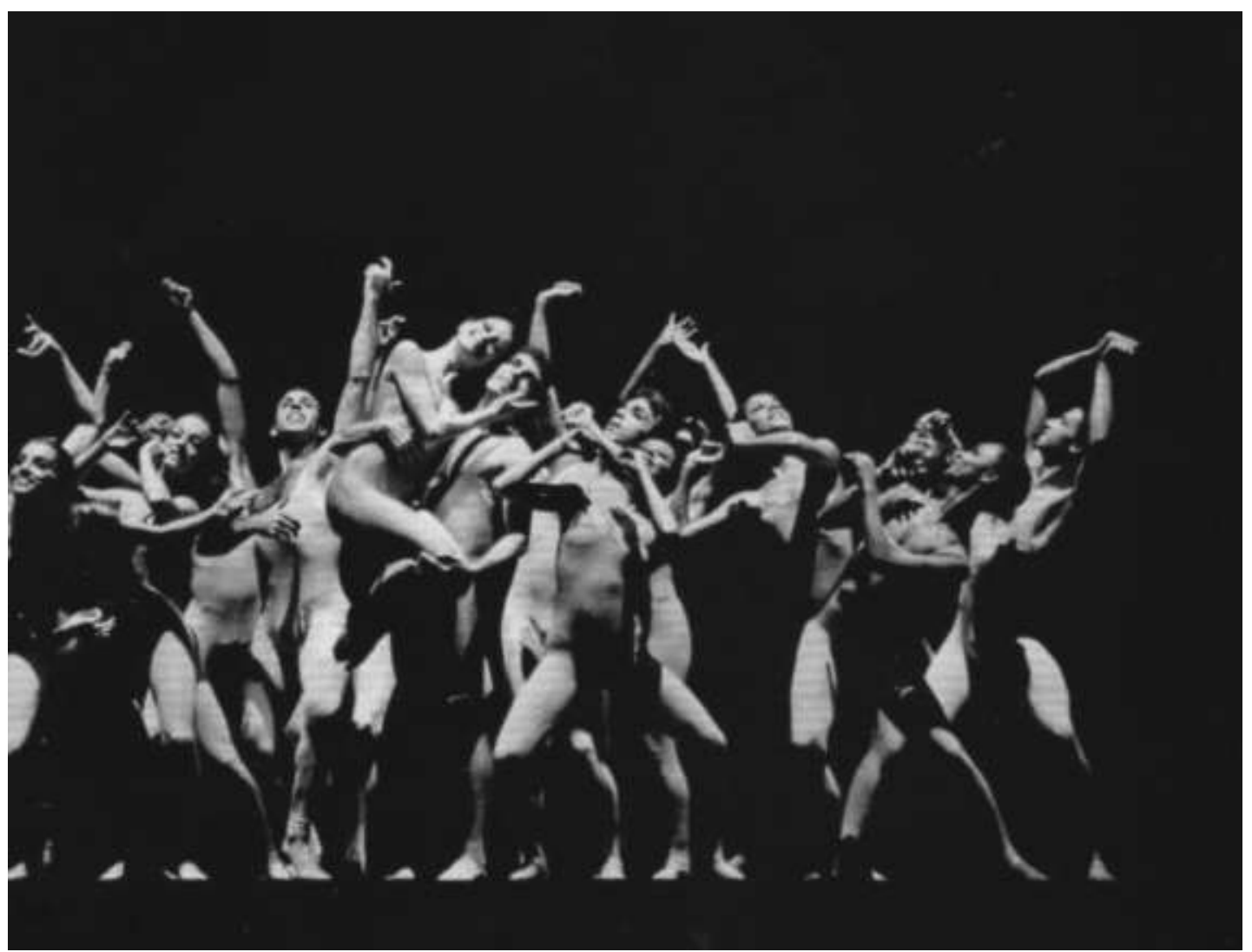

Ilustração 22 - Diadorim, com o Balé Stagium 


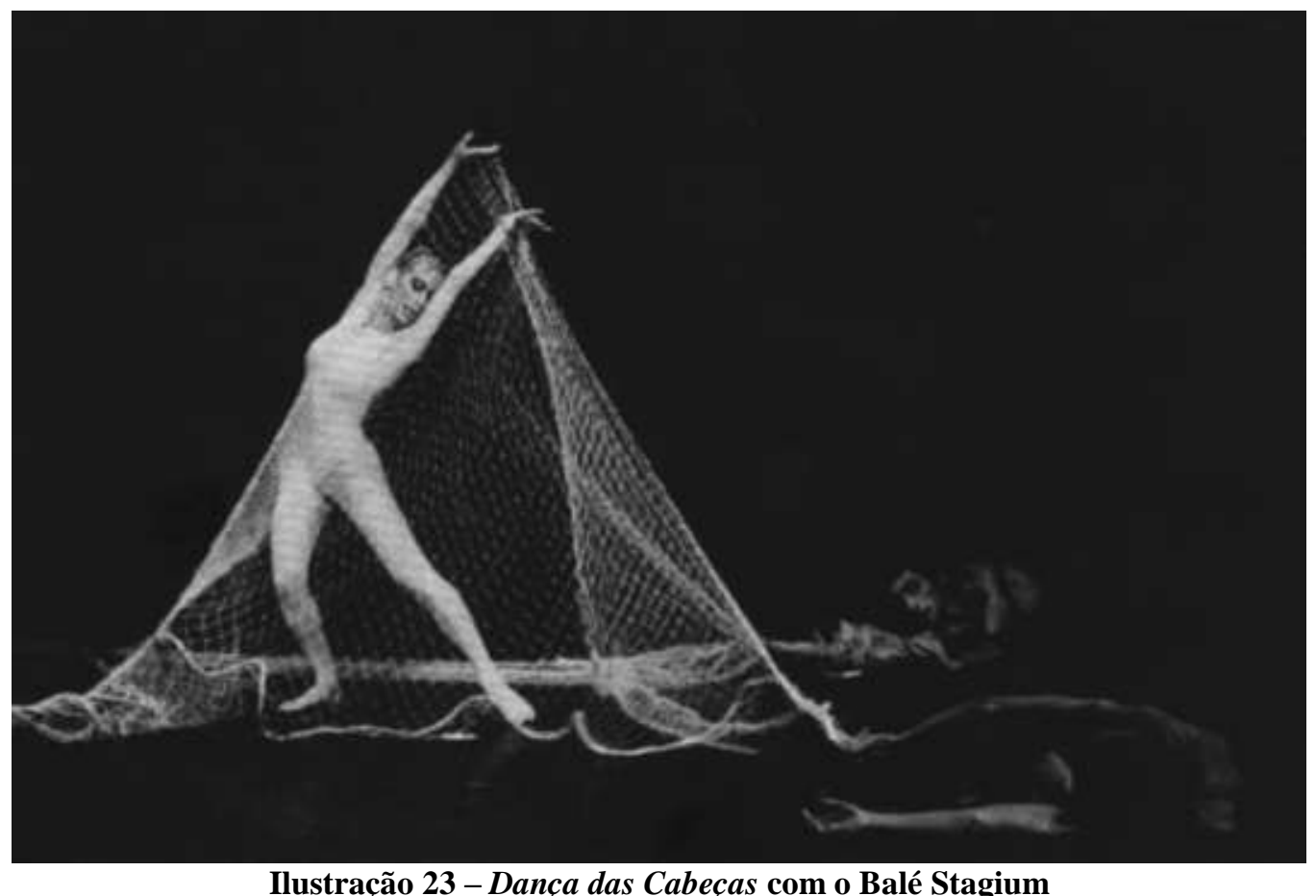

Ilustração 23 - Dança das Cabeças com o Balé Stagium

112 